\title{
Quality and postharvest performance of cut roses grown in root media containing coal bottom ash
}

\author{
Marlene Karen Cross \\ West Virginia University
}

Follow this and additional works at: https://researchrepository.wvu.edu/etd

\section{Recommended Citation}

Cross, Marlene Karen, "Quality and postharvest performance of cut roses grown in root media containing coal bottom ash" (2000). Graduate Theses, Dissertations, and Problem Reports. 3176.

https://researchrepository.wvu.edu/etd/3176

This Dissertation is protected by copyright and/or related rights. It has been brought to you by the The Research Repository @ WVU with permission from the rights-holder(s). You are free to use this Dissertation in any way that is permitted by the copyright and related rights legislation that applies to your use. For other uses you must obtain permission from the rights-holder(s) directly, unless additional rights are indicated by a Creative Commons license in the record and/ or on the work itself. This Dissertation has been accepted for inclusion in WVU Graduate Theses, Dissertations, and Problem Reports collection by an authorized administrator of The Research Repository @ WVU.

For more information, please contact researchrepository@mail.wvu.edu. 


\title{
QUALITY AND POSTHARVEST PERFORMANCE \\ OF CUT ROSES \\ GROWN IN ROOT MEDIA CONTAINING \\ COAL BOTTOM ASH
}

\author{
Marlene Cross \\ Dissertation submitted to the \\ College of Agriculture and Forestry \\ at West Virginia University \\ in partial fulfillment of the requirements \\ for the degree of \\ Doctor of Philosophy \\ in Plant Science \\ Bradford C. Bearce, Ph.D. Chair \\ Rajeev Arora, Ph.D. \\ Devinder K. Bhumbla, Ph.D. \\ Alan J.Sexstone, Ph.D. \\ Richard B. Thomas, Ph.D. \\ Department of Plant and Soil Science \\ Morgantown, West Virginia \\ 2000
}

Keywords: Rosa $x$ hybrida, flower senescence, cell wall calcium 


\begin{abstract}
Quality and Postharvest Performance of Cut Roses Grown in Root Media Containing Coal Bottom Ash
\end{abstract}

\author{
Marlene Cross
}

The vase life of roses grown in coal bottom ash (CBA) -amended media was evaluated. CBA is enriched in calcium, a nutrient implicated in delaying senescence. Four rose cultivars, Cara Mia, Dakota, Santa Fe and Pink Osiana, were grown (from started eye plants) in four media: a 50\% CBA medium and a peat:vermiculite medium amended with calcitic and dolomitic lime (1:1) were used as "high calcium" media, whereas a $25 \%$ CBA medium and a peat:vermiculite medium amended with dolomitic lime only were used as "low calcium" media. Yield was not different for roses from different media, and a subjective visual and scent assessment by a panel of judges showed no media effect. Vase life of the freshly harvested roses was evaluated over several days. Elemental analysis of the leaves showed that roses grown in the "high $\mathrm{Ca}$ " media had greater $\mathrm{Ca}$ in the leaf tissue as well as longer vase lives (12.6 and 13.5 days) when compared to those grown in the low Ca media (12.1 and 10.9 days). However, petal tissue $\mathrm{Ca}$ was not affected by media and was not correlated with vase life. Petal tissue $\mathrm{Ca}$ was approximately 12 times lower than leaf tissue $\mathrm{Ca}$. $\mathrm{Ca}$ and $\mathrm{Mg}$ increased in the petal tissue over the vase life of the senescing petals. A comparison of Cara Mia, Pink Osiana (vase life of 14 and 16.5 days), Dakota, and Santa Fe (vase life of 8.5 and 9.4 days) showed that the longer lived Cara Mia and Pink Osiana had lower leaf and petal Ca levels. Cara Mia and Dakota followed a similar kinetics of electrolyte leakage (total E.C. and $\mathrm{K}^{+}$) during their respective vase lives. In both cultivars, the cell wall fraction comprised about one half of the petal dry weight and virtually all of the petal calcium was found in this fraction. Hot water-extractable calcium decreased over the vase life, while tightly held calcium increased. Ethylene production was greater for the longer lived cultivar, but the peak in ethylene production occurred later, correlating with vase life. 
This work is dedicated to

My teacher, my inspiration, my father,

\section{Melo Maiolie}

Wealth we are told is power and knowledge is power

But there is a mightier force in this world

Than either of these - it is truth.

-a Mennonite saying 


\section{Acknowledgements}

I would like to thank my committee members: Dr. Bearce, Dr. Arora, Dr. Bhumbla, Dr. Sexstone, and Dr. Thomas. Your help and positive criticism has made this such an enjoyable learning experience and has taught me so much. To Sue, Gail, Carol, and all of the Greenhouse Staff, thanks for your support, advise, encouragement and help, without which none of this work could have been done. Thanks to Donna, Calin, Dr. Verlinden, and Kenny for all your help and good conversations about the mysteries of science. I would like to acknowledge Dr. Thayne and Dr. Townsend for their assistance with all of the statistical analyses. And especially, I thank my family, Clarence, Sam, Robin, Jimmy, Mom and Dad for their unwavering support. 


\section{CONTENTS}

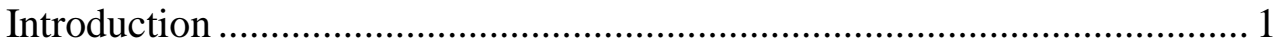

Chapter 1 - Literature Review .......................................................... 4

Factors Affecting Postharvest Life .......................................... 4

Preharvest Factors ............................................................ 4

Postharvest Factors........................................................ 8

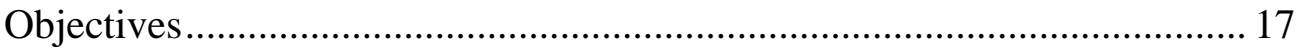

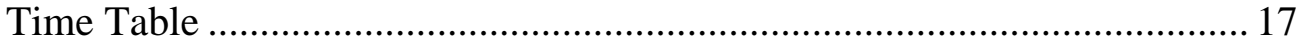

Chapter 2 - Vase Life , Media Study and Yield........................................ 18

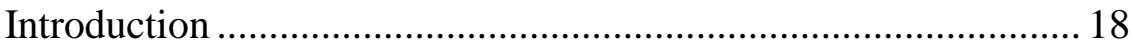

Material and Methods............................................................. 21

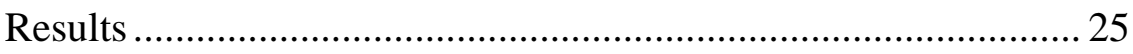

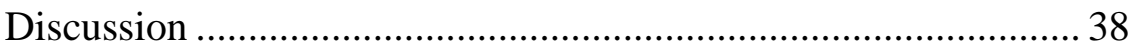

Chapter 3 -Color and Visual Assesment.................................................... 39

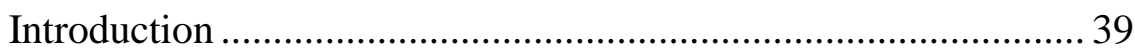

Material and Methods............................................................. 41

Results ............................................................................... 42

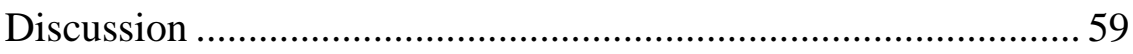

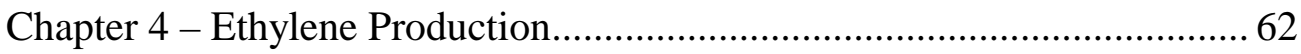

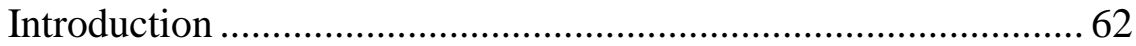

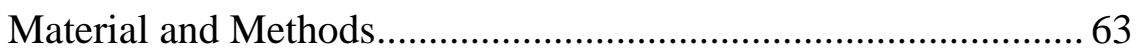

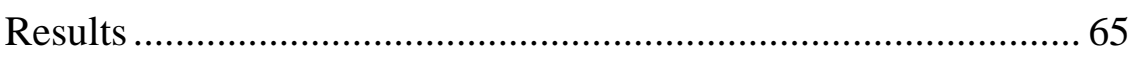

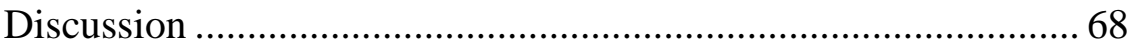

Chapter 5 -Calcium in Rose Tissue and Cell Walls ................................... 70

Introduction ............................................................................ 70

Material and Methods................................................................ 72

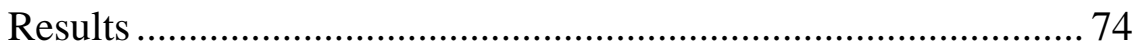

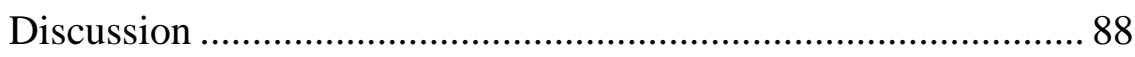

Chapter 6 -Membrane Leakage ............................................................. 91

Introduction .......................................................................... 91

Material and Methods............................................................. 92

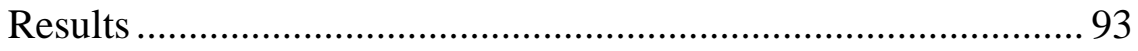

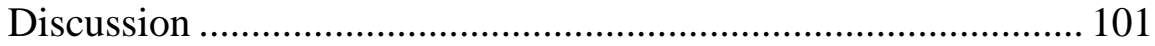

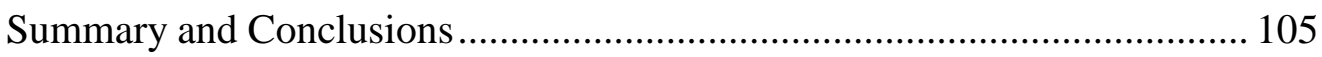




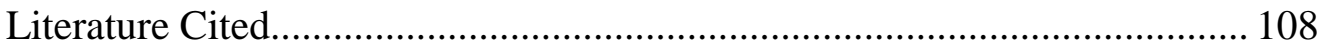

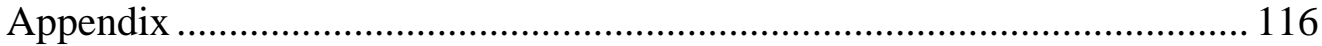

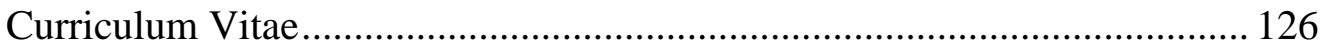

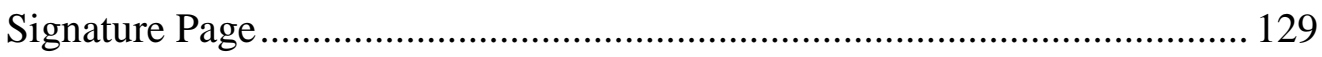

\section{List of Figures}

Figure 1.1 Ethylene Biosynthesis ............................................................... 14

Figure 2.1 The four roses used in this study................................................ 27

Figure 2.2 Media and greenhouse bench................................................... 28

Figure 2.3 Greenhouse layout.................................................................. 29

Figure2.4 Cutting stage and senescing roses.............................................. 30

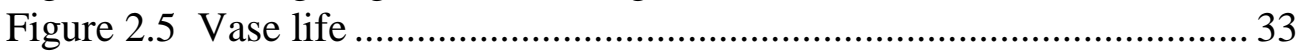

Figure 2.6 Media incubation, $\mathrm{P}: \mathrm{V}-\mathrm{pH}$ and calcium.................................. 34

Figure 2.7 Media incubation, $\mathrm{CBA}-\mathrm{pH}$ and calcium................................. 35

Figure 2.8 Media incubation - $\mathrm{pH}$ change over time...................................... 36

Figure 3.1 Petal color $-L^{*}$ values................................................................. 45

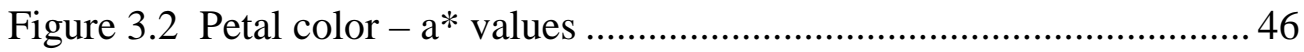

Figure 3.3 Petal color - b* values .............................................................. 47

Figure 3.4 Petal color - chroma .................................................................. 48

Figure 3,5 Petal color - hue ......................................................................... 49

Figure 3.6 Petal hue affected by media - Pink Osiana.................................. 51

Figure 3.7 Leaf $\mathrm{L}^{*}$ values ...................................................................... 52

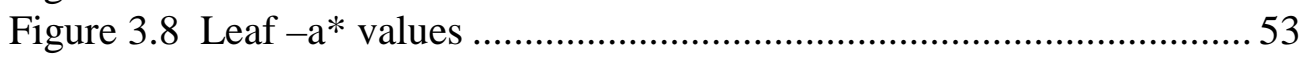

Figure 3.9 Leaf $-\mathrm{a}^{*}$ values affected by media............................................... 54

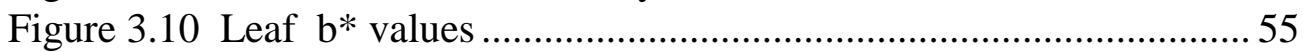

Figure 3.11 Leaf $b^{*}$ values affected by media.......................................... 55

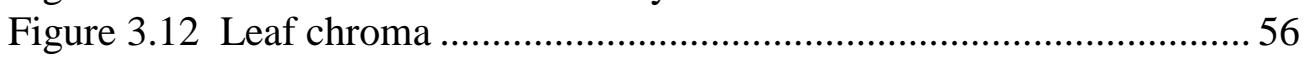

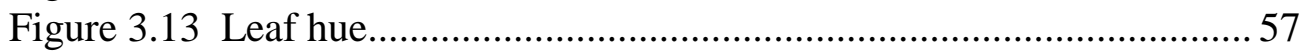

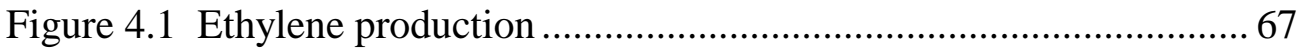

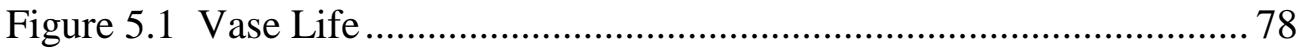

Figure 5.2 Calcium in the leaf tissue........................................................ 78

Figure 5.3 Calcium and magnesium in petal tissue (\%).............................. 80

Figure 5.4 Calcium and magnesium in petal tissue (per flower).................. 81

Figure 5.5 Magnesium in petal tissue affected by media ............................. 82

Figure 5.6 Amount of cell wall isolated (\%) .............................................. 83

Figure 5.7 Amount of cell wall isolated (per flower) ..................................... 84

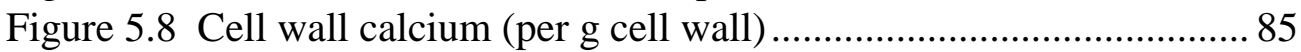

Figure 5.9 Cell wall calcium (per g dry wt.) …………............................ 85

Figure 5.10 Cell wall calcium (per flower) ……………............................ 86

Figure 5.11 Calcium in cell wall and total calcium (\%)............................... 87

Figure 6.1 Membrane leakage .................................................................... 95

Figure 6.2 Potassium from leakage and from heat-killing (\%) ................... 96

Figure 6.3 Potassium from leakage and from heat-killing (per petal).......... 97

Figure 6.4 Calcium from leakage and from heat-killing (\%) ........................ 98 
Figure 6.5 Calcium from leakage and from heat-killing (per petal)..... 99

Figure 6.6 Calcium allocation 100

\section{List of Tables}

Table 2.1 Media incubation study - components ........................................ 31

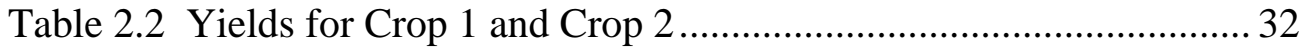

Table 2.3 Media analysis - Crop 1 ........................................................... 37

Table 3.1 Hue, $\mathrm{a}^{*}$ and $\mathrm{b}^{*}$ affected by media - Cara Mia roses ................... 50

Table 3.2 Subjective visual assessment................................................ 58

Table 3.3 Subjective assessment of scent.............................................. 58

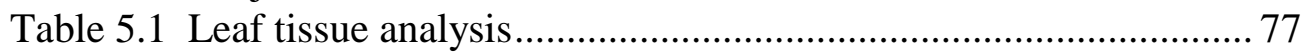

Table 5.2 Petal tissue analysis $-\mathrm{Ca}$ and $\mathrm{Mg}$.......................................... 79

\section{Appendix - List of Figures and Tables}

Table A.2.1 Calcitic and dolomitic lime .................................................. 117

Table A 2.2 Mean vase life ................................................................. 117

Figure A.3.1. Rose judging questionaire .................................................... 118

Figure A.4.1 Ethylene production affected by media.............................. 119

Figure A.4.2 Ethylene production - scatter plots ................................... 120

Figure A.4.3 Statistical model for ethylene data analysis ......................... 121

Figure A.5.1 Cell wall material (\%) affected by media.............................. 122

Figure A.5.2 Cell wall material (\%) affected by media.............................. 123

Figure A.5.3 Cell wall material (per flower) affected by media ................. 124

Figure A.6.1 Statistical model for leakage data analysis............................ 125 


\section{Abbreviations Used in this Paper}

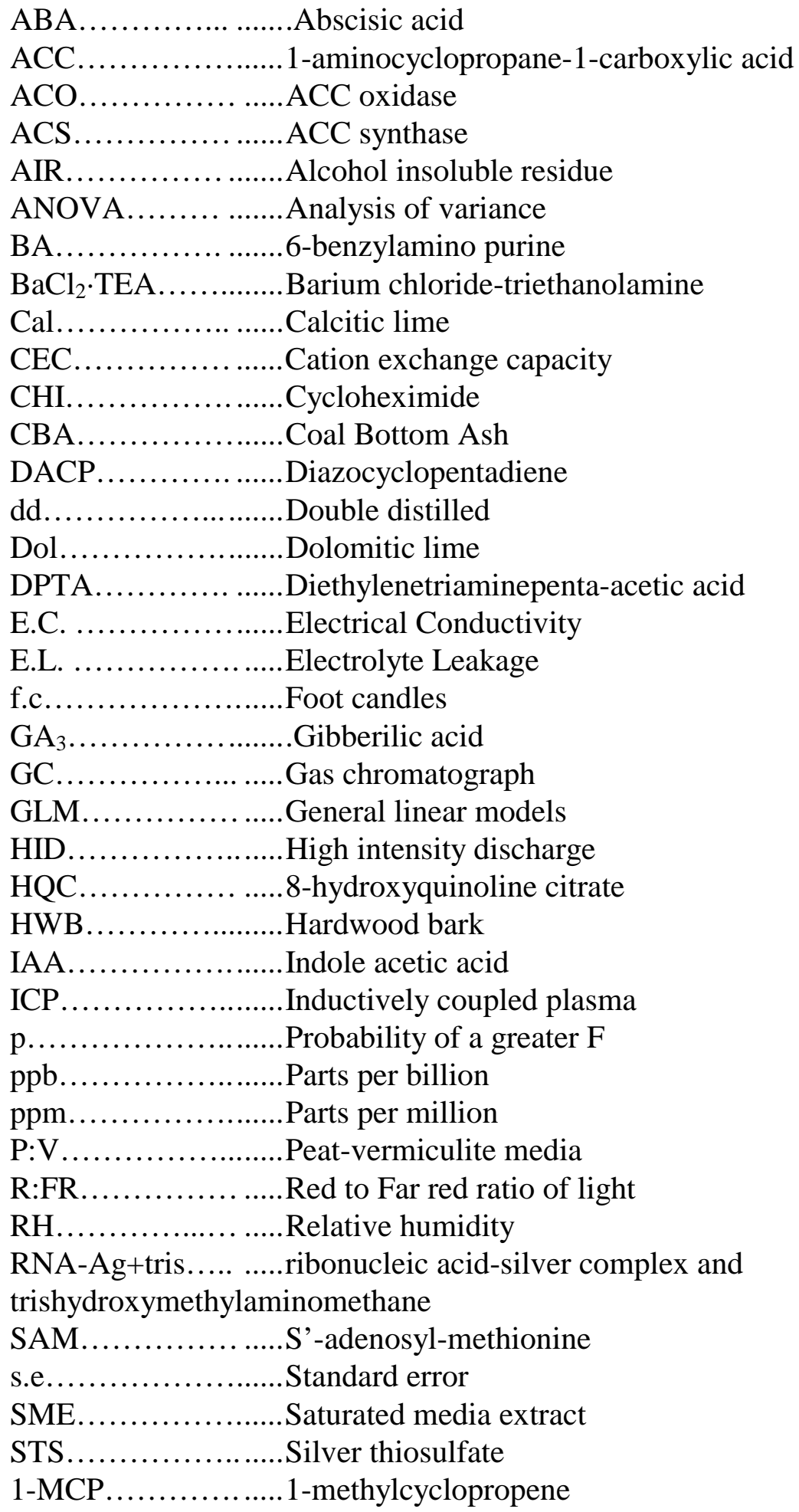




\section{INTRODUCTION}

When we think about senescence in a flower, we can think of it as a natural process. The plant has expended a great deal of energy on the flower in order to attract pollinators. The showy petals, the wonderful scent, the nectar, and even sometimes excess pollen, are all produced for this end. Once pollinated, though, the plant has no more need of the parts of the flower that we enjoy. The production of the seeds and fruit become the priority.

Senescence of the flower serves an important function in this respect. This process begins to break down cell membranes and to send metabolites from these nolonger needed flower parts to the all-important developing ovary.

Regardless of mother nature's intent, the rose producer has a different goal in mind - to produce a cut rose that will remain beautiful for the consumer for as long as possible. An understanding of the natural processes of senescence will shed light on what can be done to extend the vase life and quality of these lovely flowers.

\section{What Happens as a Flower Senesces?}

There is a great deal of variation in the way that different flowers senesce, and for this reason, this topic can be very confusing. It may be helpful to begin this discussion with some general concepts that are involved in this process.

Senescence of the perianth is a positive and important process to the flower. After the petals have served their purpose, the plant no longer would profit by sending food to them. Some plants abscise their petals at this point; for some, the process involves a more gradual wilting followed by abscission. In other plants, petals wilt and are retained. When the petals undergo wilting, the plant has the added advantage of being able to reabsorb some of the metabolites before the petals fall. It has been shown that carbohydrates from the wilting petals are transported to the ovary (Halevy and Mayak, 1981). 
On a cellular level, several things happen at the onset of senescence. There is a new set of genes transcribed; some of the first to be characterized were galactosidase, glutathionine S-transferase, and enzymes in the ethylene synthesis pathway (O'Neill and Nadeau, 1997). Many other "senescence" proteins are thought to be newly made at the onset of senescence, too, though in much smaller amounts. These include proteins involved in protein and nucleic acid degradation and in lipid and nitrogen mobilization (Buchanan-Wollaston, 1997). Following this de novo protein synthesis, there is an increase in respiration - called a respiratory climacteric (Mor and Zieslin, 1987). The spike in respiratory activity may be an alternate pathway since it is insensitive to cyanide. The third event to occur is the hydrolysis of many cell components; most notably, there is a loss of phospholipids. Borochov, et al. (1982) found that in rose petals, senescence was accompanied by a decrease in membrane fluidity. They determined that this resulted from phospholipid loss from the membrane due to enhanced degradation by phospholipase A and also reduced phospholipid synthesis. This loss of phospholipid causes a concurrent decrease in membrane integrity. The loss of mitochondrial membrane integrity causes a decrease in mitochondrial functioning (oxidative phosphorylation and electron transport are uncoupled and the cell's supply of ATP decreases) (Halevy and Mayak, 1979). Loss of plasma membrane integrity may also cause leakage of ions from the petal cells and wilting of the petals (Torre et al., 1999). The theory that leakage explains wilting is often proposed, but recent evidence has been presented that indicates that petal wilting and loss of membrane integrity may be independent (Ketsa and Rugkong, 1999). Now, respiration declines, RNase activity increases, and both proteins and carbohydrates are transported out of the cell. The final step is the degradation of DNA and autolysis of the cells.

The biggest thrust of research in this area is to discover what triggers and regulates this process. Two different mechanisms may be acting, depending on the flower in question. Some flowers seem to senesce purely on a temporal schedule, e.g. the day lily. Bieleski (1995) has reviewed daylily senescence, describing the flow of carbohydrate and tissue $\mathrm{N}$ and $\mathrm{P}$ from the senescing petals. 
In other flowers, senescence seems to be triggered by the pollination of the flower. The most extreme case of pollination-controlled senescence is the orchid. Orchid flowers may last for weeks or even months if not pollinated, but will senesce rapidly as soon as pollination occurs. The signaling mechanism is thought to be some as yet unidentified molecule or molecules from the pollen grain. This signal from the pollen grain (for petunias and Easter cactus) has been found to reach the ovary long before the pollen tube does (Karle and Boyle, 1999). The immediate effect of that signal, that starts the senescence process in orchids and petunias, is the formation of ethylene (O'Neill and Nadeau, 1997) (Karle and Boyle, 1999).

In a great many flowers, senescence is regulated by a combination of these two mechanisms. Ethylene, a plant hormone that can freely move through plant tissues, is thought to play a major role in the process. It is thought to be directly involved in transcriptional regulation.

Roses are thought to respond to pollination by an increased rate of senescence in which the perianth wilts first, then abscises (O'Neill and Nadeau, 1997). The role of ethylene in rose senescence is not completely clear. It is agreed that roses are sensitive to exogenous ethylene, which speeds up the process of senescence. But as to the part played by endogenous ethylene in natural rose senescence, there are conflicting reports. Reid et al. (1989) report that ethylene is unimportant in rose senescence unless present exogenously. Conversely, Mor and Zeislin (1987) and Mayak and Halevy (1972) showed endogenous production of ethylene by roses at the terminal stage of senescence, and found that a competitive inhibitor of ethylene action, silver thiosulfate (STS), delayed senescence. The levels of ethylene produced by roses are very low compared to amounts produced by carnations and petunias, and measurement difficulties may account for this controversy. Müller et al. (2000) have isolated a putative ethylene receptor in Rosa x hybrida and found that the genes for two enzymes in the ethylene synthesis pathway are up-regulated during senescence. This adds weight to the theory that ethylene plays a part in rose senescence. 


\section{Chapter 1 - Literature Review}

\section{Factors Affecting Postharvest Life}

Many factors affect the quality and vase life of a cut rose. We can consider these factors in two groups: treatment before harvest, and treatment of the cut roses at harvest and beyond. While it is convenient to look at these factors separately, they interact with each other in the natural process of flower senescence.

\section{Pre-harvest Factors}

\section{Genetic Factors}

The genetic compliment of a rose cultivar can have a pronounced effect on the longevity of the cut flowers. Any genes involved in the natural senescence process, as well as any genes involved in a response to the stresses that the flower is subjected to by cutting, could affect longevity and flower quality. For example, the efficiency of the stomatal mechanism, which helps the cut rose to maintain a constant water potential, has been shown to account for the genetic differences in longevity in two cut rose cultivars. ('Baccara' roses, which have a long vase life, are able to close their stomata to a much greater degree upon being cut than can 'Golden Wave', which has a short vase life.) (Mayak, et al., 1974).

Varietal differences in longevity have been shown in many cases. The miniature roses Rosa L. 'Meirutral' and 'Meijikatar' (red sunblaze and orange sunblaze) were compared under normal interior conditions. Red sunblaze always had greater longevity than orange sunblaze (Cushman et al., 1994.) In two other miniature roses ('Bronze' and 'Vanilla'), it was suggested that differences in longevity were due to differences in the expression of a putative ethylene receptor gene (Müller et al., 2000).

In the case of gerbera daisies (Gerbera jamesoni), a breeding program was undertaken to increase vase life. By selecting flowers with the longest vase life and crossing them for two generations, the breeders increased vase life by 3.4 days (Wernett et al., 1996). A genetic variation for flower longevity has also been demonstrated for Easter and holiday cactus (Scott et al., 1994) and tulips (Van Eijk and Boom, 1976). 


\section{Light}

It has been generally accepted that brighter light, during the time of flower development, will produce a cut flower that has an optimal carbohydrate level and will therefore be of high quality with a longer vase life. The following results have been obtained: roses cut in November or December have a shorter shelf life than those cut in July to September. Roses cut at 8:00 in the morning have a shorter shelf life than roses cut at 4:30 after a day of sunlight. Roses cut from lower on the plant, where the leaves were shaded, have a shorter shelf life than those cut from the top (Boodley, 1969). The same effects of low light have been found in chrysanthemums, and the effects have been totally overcome by the proper metabolic sugars in the vase water (Halevy and Mayak, 1979). This indicates carbohydrate status as the critical factor.

In an experiment with supplimental light during winter on 'Samantha' roses, Roberts et al. (1993) found that rose vase life was not affected by three different light qualities. Vase life was 10 days for all treatments. However, the type of light used did affect stem length, number of flowers per plant and fresh weight of flowers. The authors found that increasing the far red : red ratio increased the number of flowers without decreasing the fresh weight and only slightly decreasing the stem length. In their experiment, a metal halide lamp with an R:FR ratio of 1:0.26 gave the highest quality flowers.

Some evidence of light affecting rose color has been reported. In 'Baccara' roses, exposure to three days of shade during the period 4-7 days before harvest, caused a decrease in anthocyanin content and increased "blueing" (Halevy and Mayak, 1979). This effect was overcome by high $\mathrm{CO}_{2}$ during flower development. Similarly, a paling of flower and stem grown under low light ('Carol' and 'Golden Wave' roses) was overcome by placing the cuts in a sucrose solution. It was shown that this "recoloring" caused by sucrose involved increasing anthocyanins in 'Carol' and an increase in carotenoids in 'Golden Wave'.

The combinations of pigments in the petals, and their bonding with each other and other phenolic molecules, called copigmentation, is responsible for the color in roses 
(Lancaster et al., 1994). It is affected not only by light, but also by $\mathrm{pH}$, temperature, metal ions, and concentration and type of copigments present (Mazza and Brouillard, 1990).

Light can also influence postharvest performance of roses. Cut roses exposed to constant light or 12 hours of light per day lost 5 times more water than roses kept in darkness (Halevy and Mayak, 1981). This, it is thought, was due to stomatal opening caused by the light. Abscisic acid (ABA) or aluminum ions reduced this effect by inducing the stomata to remain closed.

In two poinsettia varieties - 'Eckespoint Lilo' and 'Gutbier V-10 Amy' - low light stress (as in a home environment) decreased the chlorophyll a:b ratio and also caused changes in the total amount of chlorophyll in the leaves (Embry and Nothnagel, 1994). Eckespoint showed an increase in chlorophyll, and had less leaf abscission and greater longevity than Gutbier. In Gutbier, low light caused loss of chlorophyll resulting in leaf abscission and a shorter shelf life of the plant.

\section{Fertilization and Soil}

It is usually assumed that if the fertility and structure of the growing medium is within the range for optimal plant growth, there will be little or no effect on the longevity of the roses (Boodley, 1969). Outside of this range, the effects of some deficiencies or excesses are known. Potash deficiency decreases lasting life of roses. Excess potash can cause blueing in red roses while reducing the likelihood of neck wilt (Boodley, 1969).

High salts decrease longevity, especially in conjunction with infrequent watering, (Halevy and Mayak, 1979). This is probably due to water stress, or more specifically, change in the osmotic pressure. When the concentration of salts in the soil solution is high compared to that in the plant sap, it is much more difficult for the plant to pull water into the roots; instead the tendency would be for water to be pulled out of the roots due to the water potential gradient.

Wax ginger, Tapeinochilus ananassae, (Broschat, 1995) was grown with three different fertilization rates. It was found that fertilization rate did not affect longevity of 
these cut flowers except at the highest concentration. At this highest rate $(4440 \mathrm{~g}$

Osmocote $17-3-10 \cdot \mathrm{m}^{-3} \cdot \mathrm{yr}^{-1}$ ) longevity was reduced.

\section{Calcium}

Calcium $\left(\mathrm{Ca}^{2+}\right)$ deficiency decreases vase life and also may prevent normal opening of roses (Boodley, 1969). Calcium is often added to preservative solutions; a preservative solution with $0.1 \% \mathrm{Ca}\left(\mathrm{NO}_{3}\right)_{2}$ has been found to prevent stem softening in some roses (Halevy and Mayak, 1981). Calcium has also been used, by direct application, to reduce post harvest senescence symptoms in lettuce and apples (Poovaiah et al., 1988). In apples, it reduces the rate of ethylene and $\mathrm{CO}_{2}$ production.

Calcium has many functions in the cell. It is involved in cell wall structure, in cell membrane integrity, and also plays a regulatory role in many cell processes. In the cell wall, $\mathrm{Ca}^{2+}$ can delay the breakdown of polymers. Poovaiah et al. (1988) propose that $\mathrm{Ca}^{2+}$ does this by crosslinking galacturonans in the cell wall. Also, low $\mathrm{Ca}^{2+}$ leads to loss of pectate from the middle lamella.

Calcium deficiency has been shown to increase the breakdown of mitochondrial, endoplasmic, and cytoplasmic membranes (Poovaiah et al., 1988). It associates with the outside of the plasma membrane as a divalent ligand and stabilizes it (Thompson, 1988). In an experiment with cucumbers, Ferguson et al. (1983) have shown that $\mathrm{CaCl}_{2}$ decreases chlorophyll loss, ethylene production, $\mathrm{CO}_{2}$ climacteric, and peroxide content. $\mathrm{MgCl}_{2}$ and $\mathrm{KCl}$ did not have this effect. Ferguson proposes that $\mathrm{Ca}^{2+}$ has a regulatory role in senescing tissue.

Endogenous $\mathrm{Ca}^{2+}$ is present only in very small amounts in the cytoplasm (less than micromolar). It is actively pumped out of the cell or stored in vacuoles, mitochondria, chloroplasts, and endoplasmic reticulum. This low cytoplasmic concentration of $\mathrm{Ca}^{2+}$ allows it to act as a signal molecule. An external stimulus can cause an influx of $\mathrm{Ca}^{2+}$, which can activate various enzymes by $\mathrm{Ca}^{2+}$-dependent protein kinase-mediated phosphorylation. Thus, $\mathrm{Ca}^{2+}$ has an important effect on senescence on several levels. Poovaiah (1988) has observed a decrease in the ability of $\mathrm{Ca}^{2+}$ to cause this phosphorylation as senescence progresses. 


\section{Temperature}

Temperature interacts with light in its effects on cut roses. High temperatures, especially if light is low, can deplete carbohydrate reserves and decrease keeping quality (Boodley, 1969). Temperatures as low as $15-12^{\circ} \mathrm{C}$, or as high as $27^{\circ} \mathrm{C}$, during the three weeks before harvest were observed to decrease longevity (Halevy and Mayak, 1979).

Temperature can also affect pigmentation. 'Golden Wave' roses kept at low temperatures (less than $15^{\circ} \mathrm{C}$ ) developed a greenish tint (Halevy and Mayak, 1979). This was because chloroplasts were only incompletely converted to chromoplasts. This was thought to be caused by low carbohydrate levels. High temperatures also caused the paling of 'Carol' and 'Golden Wave' roses mentioned under Light above.

\section{Air Circulation}

Botrytis blight is a foliar disease caused by the fungus Botrytis cinerea. It can decrease the yield of roses and ruin their appearance. The susceptibility of cut roses to Botrytis is directly proportional to the wind speed during the five weeks before their harvest (Hammer and Evensen, 1996). At wind speeds of $0.55 \mathrm{~m}^{-1} \mathrm{~s}^{-1}$, susceptibility was

almost double that at $0.18 \mathrm{~m} \mathrm{~s}^{-1}$. These are relatively low speed winds, and the effect is thought to be caused by subtle changes in the cuticle. (The researchers point out, though, that the effects of environmental conditions on the pathogen, such as good ventilation and humidity around the plants, is much more of a factor in disease development than the possible resistance gained by the host from this low wind.)

\section{Postharvest Factors}

\section{Cutting and Conditioning Methods}

When and how roses are actually cut also has an effect on keeping quality. Cutting when the roses are too immature can reduce longevity by $36 \%$. Bent neck is also more likely, because at the younger stage, the stem has not developed enough lignin 
(Halevy and Mayak, 1979). As mentioned above, afternoon-cut flowers last longer (by $7 \%$ in summer and $11 \%$ in winter) than morning-cut ones (Boodley, 1969).

The age of the plant may affect cut flower longevity. In wax ginger cut flowers, a long-term crop in which the plants are grown for several years like roses, there was a significant increase in vase life after the first year. The first-year flowers lasted only one week while the second-year or older flowers lasted about 14 days (Broschat, 1995).

A sharp cut that minimizes damage to the vascular tissue is important so that water uptake is optimal. If flowers are not immediately put into water, air bubbles may enter the vascular tissue, greatly decreasing water uptake and, therefore, longevity.

Roses are usually 'conditioned' as soon as they are cut. This is done to saturate them with water to assure the best possible water balance. It involves placing the cuts into deionized water that has been deaerated if possible to remove dissolved air. This water usually contains a germicide and no sugar. Better results are obtained if the water is acidified, which increases stem conductivity, or has a wetting agent added to it (Halevy and Mayak, 1981). The cut roses are then kept at $35-40^{\circ} \mathrm{F}$ for 12 hours.

\section{Water Stress}

Water stress, no matter how it is caused, has a detrimental effect on cut flowers, causing wilting that ends their shelf life. Three factors are involved in maintaining a balance of water in the cut flower: uptake and transport of water, loss of water through stomates or transpiration, and retention of water by plant tissues.

Uptake and transport of water (stem conductivity) can be inhibited by several factors. Microbial growth, and some metabolites produced by these bacteria, can block the xylem in the lower part of the stem. The bacteria suspected to be the biggest problems are Pseudomonas sp. and members of the enterobacteriaceae found in tap water (van Doorn and de Witte, 1997). Van Doorn (1998) also found that daffodils in the vase with roses can decrease their vase lives. This, it was found, was due to the sugar and polysaccharides released by the daffodil stem, which increased microbial growth. This effect was blocked when 8-hydroxyquinoline citrate (HQC) was added to the vase water. 
Injury to the stem at harvest can induce oxidative processes that cause vascular blockage, as can air bubbles introduced into the stem. But since roses with as little as $4 \%$ vascular blockage may still wilt, this must be only part of the explanation (Halevy and Mayak, 1981).

Loss of water, through stomates and transpiration, will cause wilting if this loss exceeds water uptake. Cut roses kept in the light lost five times more water than those kept in the dark because the stomates were open in the light. Stomatal efficiency is a genetic characteristic that can account for differences in longevity between two rose cultivars. Abscisic acid, aluminum ions, and calcium can also induce stomatal closing and delay wilting (Halevy and Mayak, 1981) (Poovaiah, 1988).

The ability of plant tissues to hold water is affected by osmotic potential and by membrane integrity. Sugar added to vase water of cut flowers prolongs flower life by helping to maintain the osmotic potential in the plant tissue and by adding metabolic fuel. Membrane integrity decreases as the flower senesces. Ethylene is involved in this process, as will be discussed below.

\section{Carbohydrate Status}

As a flower expands, water, nutrients, and carbohydrates are pulled into it. For this reason, the flower is dependent on the leaves and the stem. In protea flowers, Dai and Paull (1995) have found that leaf blackening can occur as a result of depletion of carbohydrates in the leaves as the inflorescence expands. Cut protea flowers with more leaves and/or in brighter light have less blackening. Most of the carbohydrate that was pulled to the protea flower went to the ovary, specifically to form nectar. It has been hypothesized (Verlinden, personal communication) that after full expansion of the flower, little else moves into the petals due to their low transpiration rate, and the declining carbohydrate balance plays a role in triggering senescence.

\section{Disease}

Diseases can drastically reduce cut flower life. The two types of most concern are vascular diseases and foliar diseases. Vascular diseases decrease cut flower life by 
blocking the vascular tissues and preventing the rose from maintaining the necessary osmotic balance. Some also produce toxins.

The foliar diseases, including mildews and Botrytis, can cause an increase in ethylene production and this in turn shortens flower life and causes petal drop (Boodley, 1969). Botrytis can also quickly ruin the appearance of the flower (Hammer and Evensen, 1996). Infections may not be visible at harvest, and may still not be noticeable when the flowers are taken out of cold storage, but it may only take a few additional hours for the fungus to express symptoms and ruin the appearance of the rose (Nichols and Nelson, 1969).

After harvest, bacteria in the vase water can have a detrimental effect on keeping quality. This effect varies according to the season, the cultivar, and the concentration of bacteria. At bacterial concentrations of $106 \mathrm{cfu} / \mathrm{ml}$. to $109 \mathrm{cfu} / \mathrm{ml}$, , neck curvature in gerbera daisies increased more than 90\% (van Doorn and de Witte, 1994). This concentration range is common to vase solutions tested from floral shops. One rose in a vase might typically have a bacterial concentration of $106 \mathrm{cfu} / \mathrm{ml}$. after 2-3 days.

Van Doorn and de Witte (1997) have found that the bacteria accumulating in the vase water are primarily Pseudomonas sp. and, to a lesser extent, members of the enterobacteriaceae. Upon tracing the source of the contamination, it was determined that the bacteria came from the tap water, which can support their growth even though it contains only trace amounts of organic compounds.

\section{Chemical Applications}

The plant growth regulator ethylene is a major player in the senescence of flowers. Roses, and many other flowers studied, follow a pattern of ethylene evolution upon being cut. There are three distinct phases. First, ethylene level is at a low steady state. This is followed by a sudden, accelerating rise in ethylene evolution to a maximum. Finally, there is a decline (Mor and Zieslin, 1987). The onset of the sudden rise in ethylene signals the terminal stage of senescence. The increase in ethylene is thought to cause a respiratory climacteric (a burst of respiration evidenced by a peak in $\mathrm{CO}_{2}$ given off), and to set in motion the sequence of events that cause senescence of the flower. Some of the 
symptoms of senescence caused by ethylene are leaf drop, bud abortion, and bud abscission (Serek et al., 1994a). More research is needed before the role of endogenous ethylene in roses is clear.

Some flowers, including the rose, are sensitive to exogenous ethylene. Adding ethylene to these flowers can trigger the flower to begin ethylene biosynthesis of (autocatalysis). Other flowers, gladiolus for example, are ethylene-insensitive. While gladiolus does produce ethylene in a set pattern as they senesce, exogenous ethylene has little or no effect on senescence (Serek et al., 1994b).

Given the correlation between ethylene production and senescence, much work has been done to inhibit ethylene synthesis and to block the action of ethylene, in order to increase flower longevity.

Silver (Ag) was found to inhibit ethylene action. When applied directly to the flowers in the form of $\mathrm{AgNO}_{3}$, it delayed senescence. One of the first inhibitors of ethylene action to be used in rose production was silver thiosulfate (STS), because in this form, silver could be added to the vase water and would be transported throughout the cut flower (Halevy and Mayak, 1981). Recently, evidence has emerged that STS does not move up through the stems of roses, but remains in the lower $5 \mathrm{~cm}$. The same is true of silver added as silver nitrate or RNA-Ag + tris (a ribonucleic acid-silver complex and trishydroxymethylaminomethane) (Ohkawa et al.,1999). [Silver nitrate and RNA-Ag + tris have been shown to extend vase life because they are antibacterial and therefore prevent bent neck (Ohkawa et al., 1999). Bent neck is a condition in which the flower bends over just below the perianth. It can occur when bacteria block the xylem in the rose stem.] STS, when sprayed on roses, can have a pronounced effect on increasing longevity in roses. For example, Cushman et al. (1994) found that STS at 2mM, sprayed on orange or red Sunblaze roses, significantly increased their longevity.

STS is used as a pulse treatment at harvest for many cut flowers. There is, however, a narrow concentration range where it is effective, in that 2 or $3 \mathrm{mM}$ is needed for effectiveness; at 4mM, it is phytotoxic. STS has very little effect on the ethyleneinsensitive flowers such as daylilies, irises, narcissus (Jones et al., 1994) or gladiolus (Serek et al., 1994b). STS, a heavy metal salt, has been criticized as being 
environmentally unsafe. Its exact mechanism of action is not well understood, but it is thought that it may be a competitive inhibitor that binds directly to the ethylene binding site on the cell membrane and may therefore prevent ethylene from binding and signaling changes in the cells (Reid et al., 1989).

In an attempt to find a chemical treatment that inhibits ethylene action as well as STS, but is not unsafe, several other compounds have been tested. DACP (diazocyclopentadiene) has been used on miniature rose plants and increases shelf life as well as STS. The mode of action is that of binding to the ethylene binding site. DACP binds there irreversibly, and does so even at very low concentrations. In fact, it has been shown to replace radioactive ethylene from these sites. It is, however, labile and explosive (Serek et al., 1994a).

Another ethylene-action inhibitor being tested is $1 \mathrm{MCP}$ (1-methylcyclopropene). On miniature roses, it has the same mode of action and effectiveness as DACP but is much safer. It can be used effectively in very low concentrations (0.5n1/1.) and even in much higher concentrations (20nl/1.) it still shows no phytotoxicity (Serek et al., 1994c).

Evidence that ethylene is a triggering compound in senescence and not a byproduct comes from genetic work done on tomatoes (Oeller et al., 1991). The researchers produced transgenic tomato plants with a mutation in the gene that coded for 1-aminocyclopropane-1-carboxylic acid (ACC) synthase. (ACC synthase is the enzyme that catalyzes the synthesis of ACC which is the direct precursor of ethylene. See Figure 1.) In these transgenic plants, antisense RNA for ACC synthase was formed and so no functional ACC synthase was made. Ethylene synthesis was inhibited 99.5\%, and fruit ripening (essentially senescence) was inhibited.

In carnations, genetic engineering has produced plants that contained antisense ACO genes (ACC oxidase, which catalyzes the formation of ethylene from ACC). With inhibition of the formation of this enzyme, the plants could produce only about $10 \%$ of the normal ethylene. Longevity of the cut flowers increased from 5 days to 9 days (Savin, et. al., 1995).

Altman and Solomos (1994) found that aminotriazole treatment of carnations increased their vase life and that the climacteric rise in respiration was greatly inhibited. 
Aminotriazole, a post-emergence herbicide, works by inhibiting the biosynthesis of ACC synthase. (See Fig.1.1 below.)

\section{Fig. 1.1 - Ethylene Synthesis}

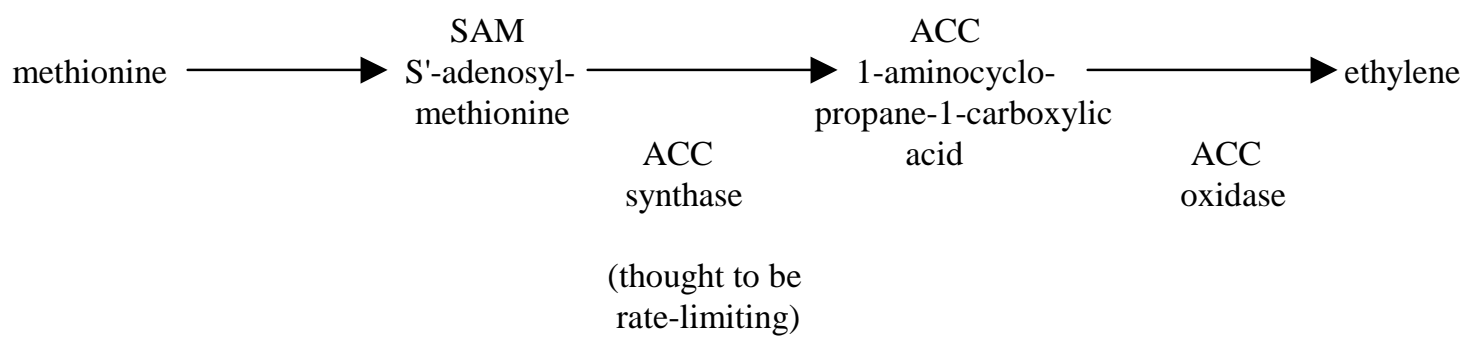

Senescence has been shown to involve de novo protein synthesis (Jones et al., 1994). Ethylene is thought to act by altering gene expression. Cycloheximide (CHI) is an inhibitor of protein synthesis. In gladiolus, iris, and narcissus, treatment with $\mathrm{CHI}$ decreased protein synthesis by $60 \%$ and increased vase life by $100 \%$. (While experiments with $\mathrm{CHI}$ may help to shed light on the process of senescence, it is not recommended as a cut flower treatment due to its toxicity to both plants and humans.) Woodson and Lawton (1988),working with carnations, have shown that ethylene's mechanism of action in causing senescence is the result of rapid changes in gene expression. The carnation petals accumulated 6 different mRNAs within 3 hours of ethylene exposure. In carnations, ethylene formation occurs first in the ovary and this ethylene, diffusing to the petals, has been shown to trigger the expression of two genes involved in ethylene production. Therefore, ethylene from the ovary is causing the petals to begin producing their own ethylene (Have and Woltering, 1997).

In addition to ethylene, other growth regulators can also affect senescence and cut flower longevity. Abscisic acid (ABA), gibberellins, auxins, and cytokinins such as 6- 
benzylamino purine (BA) are thought to be involved. Though the mechanisms are not well understood, some of the experimental findings about these hormones are described here.

Cytokinins added to the vase solution have increased life span in some rose varieties and not in others. Tjosvold et al., (1994) found that BA did not improve longevity in miniature roses, but it did reduce leaf yellowing. The concentration of BA decreases in rose petals as they age (Mor and Zieslin, 1987). Since the level of BA in petals falls and at the same time, levels in the ovary rise, it has been suggested that this is related to the mechanism whereby metabolites flow from petals to ovary as the flower ages (Smigocki, 1995).

Auxins may delay senescence; aging is accompanied by a decrease in auxin due to degradation by IAA oxidase (Halevy and Mayak, 1981).

ABA levels have been found to rise in flower petals as they age, partly in response to water stress. ABA's function in this situation may be to induce stomatal closure to help the plant maintain the proper water balance. ABA does this by allowing greater permeability of the stomatal cells to $\mathrm{Ca}^{+2}$ which then flows into the cells. Calcium appears to act as a second messenger, then, affecting hormonal control of guard cell turgor (Poovaiah, 1988).

In addition to its role in improving water balance, $\mathrm{ABA}$ appears to interact with ethylene in controlling senescence (Mayak and Halevy, 1972). The participation of these two hormones in senescence may be by way of the same pathway; application of either to cut roses produces the same pattern of senescence. In fact, evidence suggests that the rise in ethylene in aging petals causes the rise in ABA production (Mayak and Halevy, 1972). The increase in ABA always follows the ethylene rise by about two days and can be induced by exogenous application of ethylene.

$\mathrm{GA}_{3}$ may be involved in flower development and aging. One study has shown that $\mathrm{GA}_{3}$ in the flower bud will decrease if night temperatures are low $\left(13^{\circ} \mathrm{C}\right.$ instead of $18^{\circ} \mathrm{C}$ ). This causes a malformation of the rose, increasing its width and proliferating the reproductive organs (Mor and Zieslin, 1987). This effect could be prevented by injecting $\mathrm{GA}_{3}$ into the receptacles. Han (1995) found that in Easter lilies and alstromeria, $\mathrm{GA}_{3}$ in 
the vase solution delays yellowing of the leaves. In most plants, however, $\mathrm{GA}_{3}$ doesn't seem to correlate with senescence.

It is most likely that control of senescence in plants is accomplished through a balance of plant growth regulators and interactions between them, other internal factors, and the external environment. 


\section{Objectives}

1. To evaluate the effect of media containing coal bottom ash on the color, fragrance and quality of cut roses.

2. To evaluate the effect of media containing coal bottom ash on the calcium content of cut roses.

3. To relate tissue and media calcium levels to the timing and physiology of rose senescence, specifically to differences in patterns of membrane leakage.

4. To compare roses with different known vase lives as to:

-their pattern of ethylene production;

-their pattern of color change; and

-the extent that their vase life is affected by the media ash content and the petal tissue calcium.

\section{Time Table}

Fall, 1997 - Preliminary media incubation study.

Feb. $1998 \quad$ - Roses arrived and are planted.

May 1998 -Crop 1 is harvested. Longevity study, Petal color study, Yield.

Sept. 1998 -Crop 2 is harvested. Membrane leakage, Leaf and petal tissue analysis, Yield.

March $1999-50 \mathrm{~g}$ lime added to each pot to adjust $\mathrm{pH}$.

May 1999 -Crop 3 is harvested. Petal tissue analysis, Cell wall study, Vase life check.

Sept. 1999 -Crop 4 is harvested. Ethylene study, Leaf color study, Subjective visual and scent assessment. 


\section{Chapter 2 - Vase Life, Media Study and Yield}

\section{Introduction}

\section{Roses as a Cut Flower Crop}

Since 1990, the demand for cut flowers in the United States and in most temperate countries, has increased. The demand for roses, in particular, has risen even faster than that for chrysanthemums or carnations - the other two major cut flower crops (Pertwee, 1995). This increase in sales can be attributed in part to the breeding of many new and improved varieties, particularly those with better vase life. Consumers have become more confident that their roses will not bend over or die within a day, but will remain beautiful for a week or more.

Even though demand is increasing, domestic rose production is facing much competition from imported roses. Imports are supplying an increasing percentage of the market (Voigt, 1997). American growers are responding to the market challenge by consolidating and committing to mass market sales through retail chains. Currently, about one fourth of the top 100 U.S. greenhouse growers are cut flower growers. These growers planted over 26.5 million square feet to cut flowers (Onofrey, 1997).

There are several advantages to locally grown cut roses that growers can capitalize on. Shipping charges are saved and there is no decrease in vase life due to packaging and shipping time. Also, the varieties that have been bred to ship well and hold up in transport boxes have little or no scent. Local producers, however, can choose from quite a few varieties that have wonderful scents. This is a specialty market that is just beginning to be explored. With careful variety selection, such as scented roses and new varieties that yield well even through the winter, northern growers can do very well (Pertwee, 1995). 


\section{Rose Culture}

Several types of roses (Rosax hybrida) are grown for cut flowers. These include hybrid teas, floribundas, sweethearts, intermediates, and spray roses. Traditionally, roses are grown in ground beds and two layers of a plastic or metal mesh is layered above them to support the plants. Carbon dioxide may be added to maintain concentrations of $1,000 \mathrm{ppm}$ to $2,000 \mathrm{ppm}$. (Normal levels in a sealed greenhouse may be only 150 to 300 ppm.) The recommended growing temperatures are $15.5^{\circ} \mathrm{C}$ to $16.5^{\circ} \mathrm{C}$ at night and 5 to 8 degrees higher in the daytime. Sometimes, supplemental light from high intensity discharge (HID) lamps or from fluorescent lamps is used. Roses are typically given nine hours of $1,200 \mathrm{fc}$ to $1,500 \mathrm{fc}$ light at night during the winter. Light shade is used from late May until August (Nelson, 1998). Rose bushes are pinched to maintain strong, healthy plants and to time when flowers will bloom.

Roses may be grown in a medium of 2:1:1 good soil:peat:perlite. A soilless medium is also sometimes used, with careful management of fertilization. In either case, the fertilizer used must supply enough nutrients so that the foliar content of the leaves is as follows: $3.0 \%$ nitrogen, $0.2 \%$ phosphorus, $1.8 \%$ potassium, $1.0 \%$ calcium, and $0.25 \%$ magnesium (Boodley, 1981). The $\mathrm{pH}$ of the soil is usually maintained at 5.5 to 6 but the roses will actually do better at a higher $\mathrm{pH}$ if iron can be supplied in a chelated form (Nelson, 1998).

\section{Coal Bottom Ash}

Coal bottom ash (CBA) is ash left at the base of the furnace when coal is burned for electricity. While this byproduct has been put to some use as an ingredient in concrete, the great majority of it is unused and ends up in landfills.

The Plant and Soil Science Department at WVU has been experimenting with CBA as a low-cost component of growing media for greenhouse and nursery crops. They have had a great deal of success. Coal bottom ash has been used as the media in a closed loop nutriculture system to grow chrysanthemums (Dendranthema grandiflora) and marigolds (Tagetes erecta), where it performed comparably to rockwool (Bearce et al.,1993) (Woodard, 1992). 
As a component of potting mixes in amounts of up to $50 \% \mathrm{CBA}$ to a peat:vermiculite mix, CBA was an acceptable media for growing impatiens, ivy and zonal geraniums, and poinsettias (Pitchay, 1996). There was some decrease in the height of the poinsettias as the percent of CBA in the media increased, but no decrease in bract size was noted. This height decrease is actually desirable - most growers treat their poinsettias with a growth retardant to limit height (Bearce and Leach, 1989). Easter lilies also grew well in potting mixes containing up to 50\% CBA and Pepperomia viridis grew well even when $75 \%$ or $100 \%$ CBA was used (Bearce et al., 1997). Rhododendron obtusum Lindl. cv. 'Hinodegiri', a nursery crop, grew as well in a 50\% CBA media as it did in the control media (Wagner and Neal, 1984).

As a component of growing media for roses, CBA has been shown to be satisfactory (Hartley-Butler, 1993). For the production indices measured in this study number of flowers, diameter of buds, and fresh weight of flowers - the roses grown in CBA/ hardwood bark (HWB) medium did as well as or better than roses grown in a soil/peat/sand medium. The CBA/HWB media, however, required more irrigation and fertilization to maintain the proper nutrient status.

Coal bottom ash has relatively high $\mathrm{Ca}^{+2}$ content - it is $10.665 \%$ calcium oxide by weight. As the percentage of CBA in the medium increases, $\mathrm{Ca}^{+2}$ in the soil solution also increases. Pepperomia and poinsettias grown in media containing CBA have shown an increase in calcium in whole plant tissues (Bearce et al., 1997). Given the important role that $\mathrm{Ca}^{+2}$ plays in senescence, the increased $\mathrm{Ca}^{+2}$ in a CBA medium may have an effect on the vase life of roses grown in it. One objective of this research is to investigate this effect.

Coal bottom ash has a fairly high pH by itself; 7.5-8.4 (Pitchay,1996) and contains all of the essential elements. When mixed into a peat:vermiculite (1:1) base in $25 \%$ or $50 \%$ amounts, the $\mathrm{pH}$ is lowered by the acidic peat to desirable levels with little or no added lime. A medium containing 25\% - 50\% CBA has an air and water holding capacity in the recommended range and an acceptable pore volume and wet and dry bulk density (Pitchay, 1996). 


\section{Rose Vase Life}

Rose vase life for a particular cultivar is usually given in the literature from the grower's company. Quite often, these numbers are estimated by unspecific procedures and can be very variable. Results from vase life studies can only be interpreted if the conditions during the study are clearly defined and if the end point of vase life is a specific, stated point. For the present study, roses were held under conditions as near as possible to those in the literature for other vase life studies (Serek et al., 1994a) (Cushman et al., 1994). Typically, the criterion for determining the end of vase life is the first sign of wilting or petal drying. This was a clearly definable point in the four rose

cultivars used in this study. Some researchers have suggested that color monitoring could be used to indicate the end of vase life, but for these cultivars, color changed gradually and so no specific point could be chosen as an end point.

\section{Materials and Methods}

\section{Plant Material and Growing Media}

On February 14, 1998, 160 plants of Rosa x hybrida cvs. Dakota, Cara Mia, Pink Osiana and Santa Fe (Figure 2.1) were obtained as 3X bare-root, started-eye plants from Jackson \& Perkins Roses, Medford, Oregon. They were planted in 18.9 1. plastic pots at a spacing of one square foot per plant (Figure 2.2). They were maintained under standard conditions at one of the glass houses at West Virginia University. A latin square design with multiple blocks was used to lay out the different treatments, as shown in Figure 2.3. The roses were planted in four soilless media. Media 1 contained 50\% CBA and $50 \%$ of a peat:vermiculite (1:1) mix (Figure 2.2). Media 2 contained 25\% CBA and $75 \%$ of this same peat:vermiculite mix (hereafter referred to as P:V). Neither of these media contained any other amendments. Media 3 was P:V with dolomitic lime added at $1.5 \mathrm{~g} / \mathrm{l}$ and Media 4 was also P:V but a (1:1) mix of dolomitic:calcitic lime at $2 \mathrm{~g} / \mathrm{l}$ was used. Preliminary media incubation studies were done to determine the amount of lime needed to reach a target $\mathrm{pH}$ of 6.2 to 6.5 . (See below.) 
Four harvests were made: in late May, 1998; late September, 1998; late May, 1999 and early September, 1999. All flowers were cut in the morning, when sepals were reflexed and two petals had loosened from the tight bud (Figure 2.4). The cut was made leaving one five-leaflet leave above the knuckle. The knuckle is the point on the stem where the previous cut had been made. The rose was then recut under distilled water, placed in a room temperature hydrating solution of citric acid $(\mathrm{pH} 3.5)$, and tagged. Flowers were then held overnight at $3^{\circ} \mathrm{C}$. For use, each flower was recut under water to $46 \mathrm{~cm}$ and the lower leaves were removed. They were placed individually into vases of distilled water.

\section{Yield}

Yield data was recorded for harvests 1 and 2. Each flower was immediately measured for stem length, bud diameter and fresh weight. Since cuts were always made directly above the first five-leaflet leave above the knuckle (which was made by the previous cut), length measurements indicated growth since the last cutback and were comparable to what a grower would be able to harvest. The number of flowers produced by each individual plant was recorded.

\section{Flower Longevity}

Flowers were held for vase life determination at $22^{\circ} \mathrm{C}$ and $60 \% \mathrm{RH}$ with 12 hours per day of $15 \mu \mathrm{mol} \cdot \mathrm{m}^{-2} \cdot \mathrm{s}^{-1}$ light from cool white fluorescent lights. Water was changed and roses were recut every two days. Flowers were monitored daily and were considered at the end of their vase life at the first sign of petal wilting or when petal tips showed any browning or drying. 


\section{Preliminary Incubation Study}

During the fall of 1997 , before the rose bushes were ordered, a preliminary media study was conducted. The main goal of this study was to determine the most suitable proportion of $\mathrm{CBA}$ to be mixed with $\mathrm{P}: \mathrm{V}$ for the experiment, and also the appropriate amount of lime to be used in the control media. The first incubation study ran for the two weeks following October 21, 1997. Four 4-inch pots of each media were arranged on the bench in a randomized complete block design. The treatments made are shown in Table 2-1. The $\mathrm{pH}$ of the media was measured using the pour-through leachate method at day 7 , 12 and 15. An Orion EA920 pH meter with a model 91-05 combination probe was used. Soluble salts and soil density were measured at day 15 . Because the $\mathrm{pH}$ of the P:V media was above 7 with the lowest level of lime added, these pots were redone with lower lime amounts (Table 2.1, lower part). Calcium in the media was also measured by both diethylenetriaminepenta-acetic acid (DPTA) and barium chloride-triethanolamine $\left(\mathrm{BaCl}_{2} \cdot \mathrm{TEA}\right)$ extraction methods (see below under Media Analysis.)

A second incubation study was conducted with the P:V media to compare the effects of dolomitic:calcitic and dolomitic limes with respect to media $\mathrm{pH}$. Three pots of each media were made. Lime was used at 0, 2, 4, 6 and $8 \mathrm{~g} / \mathrm{l}$ concentrations. In one set, dolomitic lime alone was used and in the other, the lime was half dolomitic and half calcitic. (To compare the components of these two types of lime, see Appendix Table A.2.1.)

\section{Media Analysis}

E.C. and $\mathrm{pH}$ were monitored over the course of the experiment using a pourthrough method (Wright, 1986). Potted roses were well-watered the day before the test. Collection vessels were placed under the drainage holes of the pot. Three liters of distilled water was poured through each pot and the first $200 \mathrm{mls}$ of leachate was collected and tested for $\mathrm{pH}$ and E.C. This monitoring was done at a minimum of once a month during the 20 months of the experiment, and more often if the $\mathrm{pH}$ was changing. 
On March 26, 1999, since the $\mathrm{pH}$ had begun to decrease below the recommended $\mathrm{pH}, 50$ $\mathrm{g}$ lime was added to each pot. Media 1 and 4 received a dolomitic:calcitic mix (1:1) and media 2 and 3 received dolomitic lime alone.

Soil was analyzed for nutrients using the saturated media extract (SME) method as described by Warncke (1991). Each sample was a $400 \mathrm{ml}$ combined sample from three pots, which represented the media from top to bottom in each pot. Distilled water was added to form a slurry; the slurry was incubated for one hour, the gravity filtered through Whatman 42 filter paper. The filtrate was then analyzed for P, K, Ca, Mg, Fe, Na, Zn, B, $\mathrm{Mn}, \mathrm{Cu}$ and $\mathrm{Al}$ on an ICP (inductively coupled plasma) atomic emission spectrophotometer. Twice, the soil analysis was done using a DTPA extraction

(Warncke, 1991) which uses 0.005 M DTPA as the first $100 \mathrm{ml}$ of the saturating solution, and is otherwise done in the same way as the SME procedure. Also, during the preliminary incubation study, a $\mathrm{BaCl}_{2}$.TEA extraction was done according to the method of Kanabo and Gilkes (1987). A suspension was made of one gram of a dried soil sample in $10 \mathrm{ml}$ of $\mathrm{BaCl}_{2}$.TEA buffer at $\mathrm{pH} 8.1$ (Bascomb, 1964). The suspension was shaken on an end-over-end shaker at $16 \mathrm{rpm}$ for 1 hour, then centrifuged for 5 minutes at 2,000 rpm. The samples were then gravity filtered through Whatman 42 filter paper. Calcium was measured in these samples by atomic absorption spectrophotometery.

\section{Statistical Analysis}

Yield data was analyzed using the GLM procedure in SAS as a split-split plot with cultivar as the main plot treatment in blocks. Media was a subplot treatment arranged in a Latin square and crop (there were two used) was a sub-sub plot treatment. The statistical model is the same as that shown in Appendix Figure A.4.3. except that "Crop" replaced "Day" in the model. All flowers produced by all eight plants of each cultivar/media combination were measured, so $\mathrm{n}$ was variable depending on the number of flowers per plant. However, in most cases, $\mathrm{n}$ was between 25 and 45 .

Vase life data was analyzed using a simple GLM procedure in SAS with cultivar and media as the main effects, and including an interaction term. Separation of means, when necessary, was done using an LSD test in SAS. 
For analysis of all media results, a one-way ANOVA was performed using EXCEL. When needed, Duncan's NMRT was used for mean separation.

\section{Results}

\section{Yield}

For stem length, bud diameter, stem weight and the number of roses produced per plant, no media effect was found for these four rose cultivars (Table 2.2). The different cultivars, of course, had different characteristics with respect to these parameters. For example, Dakota had a significantly longer stem length than the other three cultivars. Cara Mia had a smaller average bud diameter and produced more flowers per plant than the other cultivars. While not pertinent to this study, it is interesting to note that the different cultivars reacted differently to the two cropping periods or seasons (a significant cultivar x crop interaction).

\section{Longevity}

While media did not affect yield, it did affect vase life. Roses grown in media 4, P:V/dol:cal, had the longest vase life, followed by roses from media 1, 50\% CBA, then media 2, 25\% CBA. Roses from media 3, P:V/dol, had a significantly shorter vase life than those from the other three media (Figure 2.5). For each cultivar, with its own characteristic vase life, the effect of media follows the same pattern. The mean vase life for each cultivar is shown in Appendix Table A.2.2.

\section{Preliminary Media Incubation Study}

Results from the first media incubation study are shown in Table 2.1 and in Figures 2.6 and 2.7. As the \% CBA in the media increased, $\mathrm{pH}$ increased. Also, as lime increased, $\mathrm{pH}$ increased, but then leveled off after approximately 5-6g of lime per liter. Density is also given in Table 2.1. Density of $100 \%$ CBA was $.7848 \mathrm{~g} / \mathrm{ml}$, while the P:V 
media had a density of only .1135 g/ml. Soluble salt levels (measured as E.C.) were far below the desired levels of 1.5-2.2 dS/m (Cornell Recommendations, 1981). Calcium levels were tested by two methods: DTPA, which is a mild acid extraction meant to measure dissolved nutrients; and $\mathrm{BaCl}_{2}$-TEA, which is a basic extraction which should measure all dissolved and exchangeable nutrients without dissolving any additional lime. DTPA extraction showed that as the percentage of CBA in the media increased, so did the level of dissolved $\mathrm{Ca}$. Also, as the amount of added lime increased, so did the level of Ca. $\mathrm{BaCl}_{2}$-TEA extracted much more $\mathrm{Ca}$ than did DTPA. For the CBA media, extractable $\mathrm{Ca}$ increased as the percentage of CBA increased only up to 50\% CBA. Above 50\% CBA, the extractable Ca decreased.

Results from the second media incubation study are shown in Figure 2.8. The pH's were not identical to those in the first study. A different lot of peat moss was used for this study (and for the mixing of all subsequent media). From the information shown in Figure 2.8, the decision was made to use the following four media mixes:

$25 \%$ CBA which had a $\mathrm{pH}$ of about 5.5 after 15 days, $50 \%$ CBA which had a $\mathrm{pH}$ of about 6.8 after 15 days,

P:V with dol lime at $1.5 \mathrm{~g} / \mathrm{l}$ which had a $\mathrm{pH}$ of about 5.8 after 15 days and $\mathrm{P}: \mathrm{V}$ with dol:cal lime at $1.5 \mathrm{~g} / \mathrm{l}$ which had a $\mathrm{pH}$ of about 6.8 after 15 days.

\section{Media Analysis}

Table 2.3 shows the results from one of the media analyses that were performed over the course of the experiment. It can be seen that $25 \% \mathrm{CBA}$ had a lower $\mathrm{pH}$ than the other three media, and that while Ca was higher in the two "high Ca" media (50\% CBA and P:V/dol:cal), it was not significantly so. Only manganese and boron were different depending on media. 

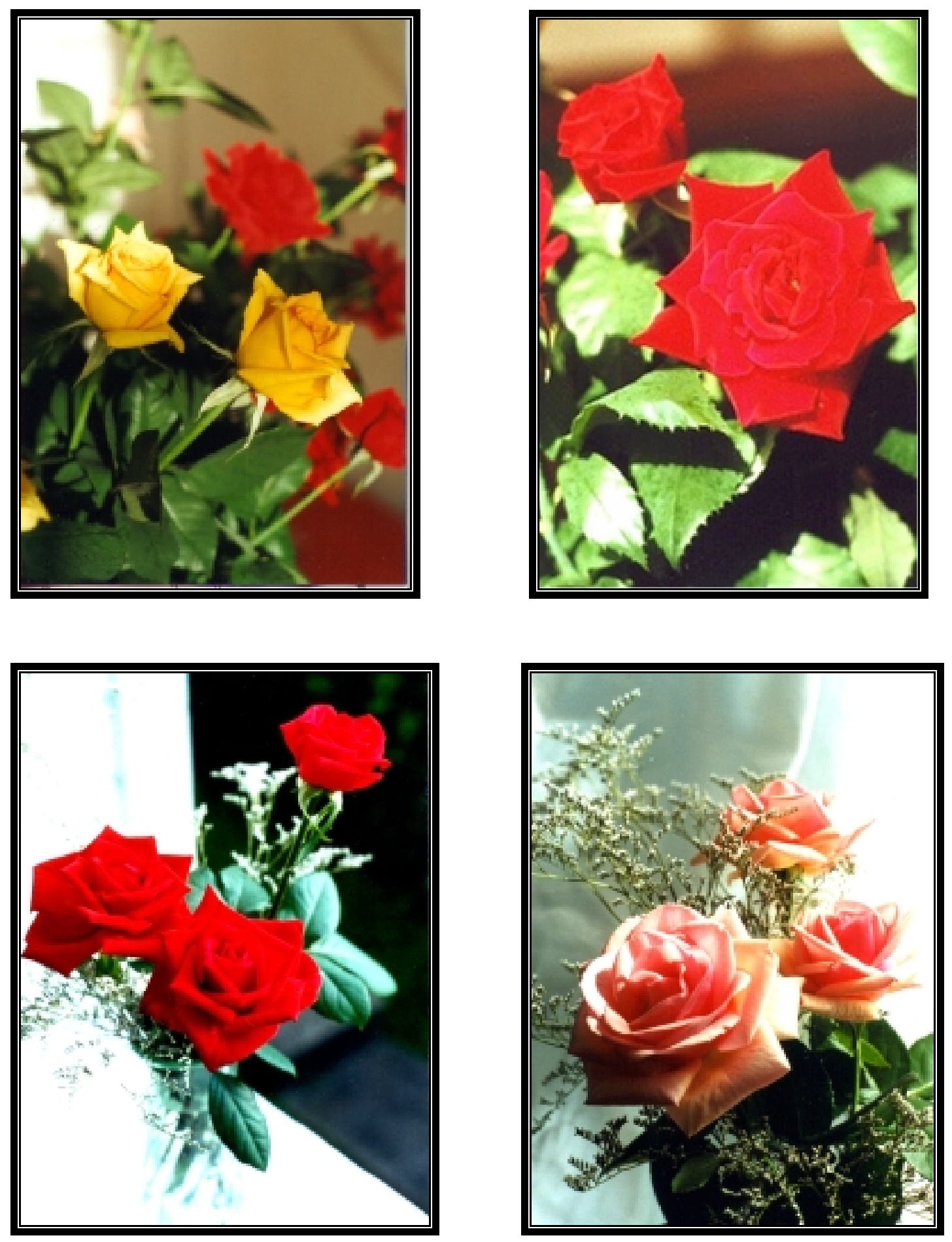

Figure 2.1 The four rose cultivars used in this research: clockwise from upper left: Santa Fe, Cara Mia, Pink Osiana and Dakota. 

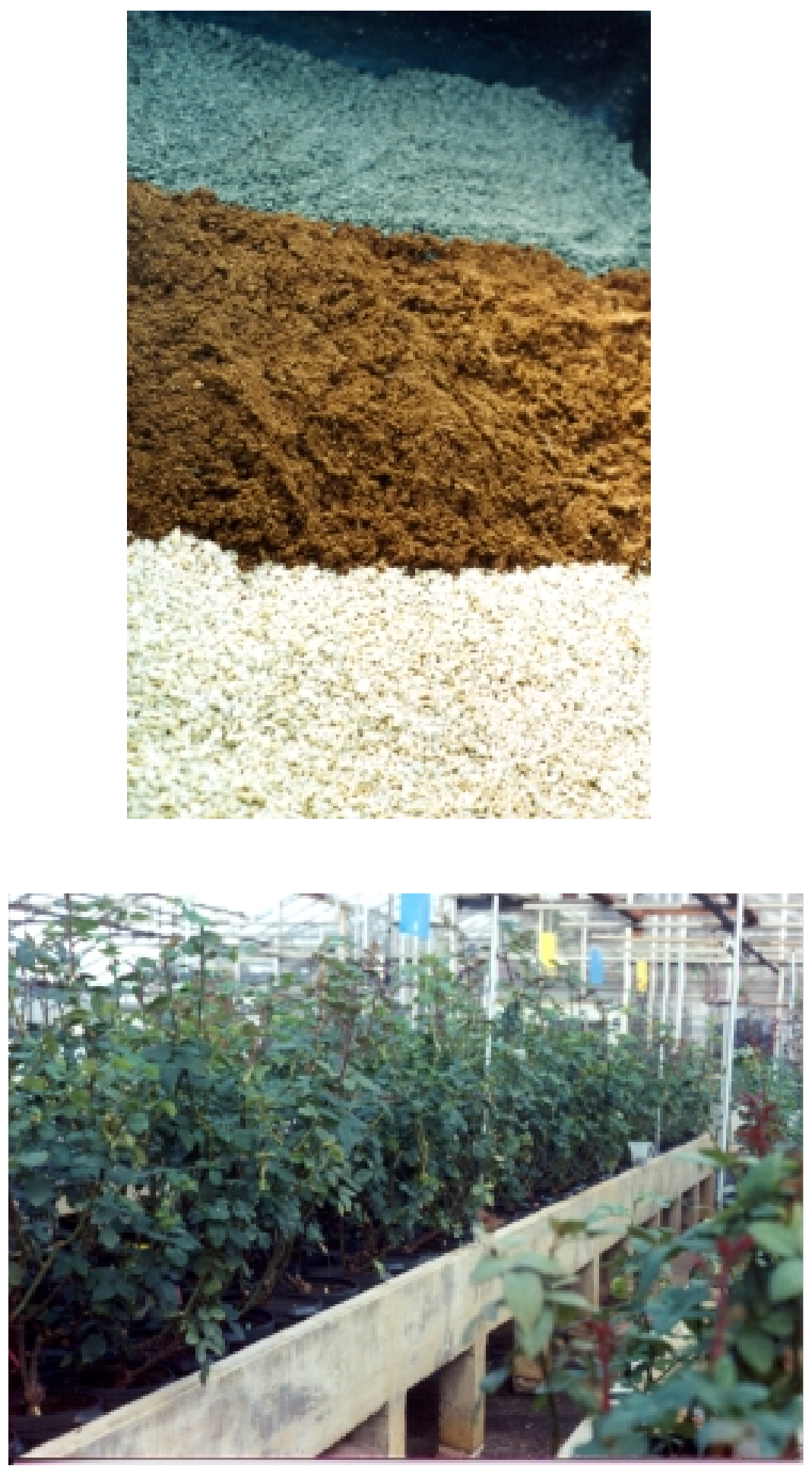

Figure 2.2 Upper photo: media components - CBA, peat moss, and vermiculite Lower photo: roses in the bench at WVU greenhouse. 


\begin{tabular}{|c|c|c|c|c|c|c|c|c|c|c|c|}
\hline $0-2-1$ & $0-4-2$ & $0-3-3$ & $0-1-4$ & $0-3-5$ & $0-2-6$ & O-4-7 & $0-1-8$ & S-3-1 & S-1-2 & S-2-3 & S-4-4 \\
\hline $0-4-1$ & $0-2-2$ & $0-1-3$ & O-3-4 & O-4-5 & $0-1-6$ & 0-3-7 & $0-2-8$ & S-4-1 & S-2-2 & S-1-3 & S-3-4 \\
\hline O-3-1 & $0-1-2$ & $0-2-3$ & O-4-4 & $0-2-5$ & $0-3-6$ & $0-1-7$ & $0-4-8$ & S-1-1 & S-3-2 & S-4-3 & S-2-4 \\
\hline $0-1-1$ & $0-3-2$ & $0-4-3$ & $0-2-4$ & $0-1-5$ & $0-4-6$ & $0-2-7$ & $0-3-8$ & S-2-1 & S-4-2 & S-3-3 & S-1-4 \\
\hline
\end{tabular}

\begin{tabular}{|l|l|l|l||l|l|l|l||l|l|l|l||}
\hline S-3-5 & S-4-6 & S-1-7 & S-2-8 & D-3-1 & D-2-2 & D-1-3 & D-4-4 & C-2-1 & C-4-2 & C-3-3 & C-1-4 \\
\hline S-1-5 & S-2-6 & S-3-7 & S-4-8 & D-2-1 & D-3-2 & D-4-3 & D-1-4 & C-1-1 & C-3-2 & C-4-3 & C-2-4 \\
\hline S-2-5 & S-1-6 & S-4-7 & S-3-8 & D-1-1 & D-4-2 & D-3-3 & D-2-4 & C-3-1 & C-1-2 & C-2-3 & C-4-4 \\
\hline S-4-5 & S-3-6 & S-2-7 & S-1-8 & D-4-1 & D-1-2 & D-2-3 & D-3-4 & C-4-1 & C-2-2 & C-1-3 & C-3-4 \\
\hline
\end{tabular}

\begin{tabular}{|l|l|l|l||l|l|l|l|||l|l|l|l||}
\hline D-1-5 & D-3-6 & D-2-7 & D-4-8 & C-2-5 & C-4-6 & C-1-7 & C-3-8 & D-2-9 & D-4-10 & D-3-11 & D-1-12 \\
\hline D-4-5 & D-2-6 & D-3-7 & D-1-8 & C-3-5 & C-1-6 & C-4-7 & C-2-8 & D-3-9 & D-1-10 & D-2-11 & D-4-12 \\
\hline D-3-5 & D-1-6 & D-4-7 & D-2-8 & C-1-5 & C-3-6 & C-2-7 & C-4-8 & D-4-9 & D-2-10 & D-1-11 & D-3-12 \\
\hline D-2-5 & D-4-6 & D-1-7 & D-3-8 & C-4-5 & C-2-6 & C-3-7 & C-1-8 & D-1-9 & D-3-10 & D-4-11 & D-2-12 \\
\hline
\end{tabular}

\begin{tabular}{|l|l|l|l|||l|l|l|l|}
\hline C-4-9 & C-2-10 & C-3-11 & C-1-12 & D-2-13 & D-1-14 & D-4-15 & D-3-16 \\
\hline C-1-9 & C-3-10 & C-2-11 & C-4-12 & D-1-13 & D-2-14 & D-3-15 & D-4-16 \\
\hline C-3-9 & C-1-10 & C-4-11 & C-2-12 & D-3-13 & D-4-14 & D-1-15 & D-2-16 \\
\hline C-2-9 & C-4-10 & C-1-11 & C-3-12 & D-4-13 & D-3-14 & D-2-15 & D-1-16 \\
\hline
\end{tabular}

Figure 2.3 Greenhouse layout for the rose bench. The first letter represents cultivar: $\mathrm{O}=$ Pink Osiana; $\mathrm{S}=$ Santa Fe; $\mathrm{D}=$ Dakota; and $\mathrm{C}=\mathrm{Cara}$ Mia. The number given next represents the media in that pot: $1=50 \%$ CBA; $2=25 \% \mathrm{CBA}$; $3=\mathrm{P}: \mathrm{V} / \mathrm{dol}$.; and $4=\mathrm{P}: \mathrm{V} / \mathrm{dol}: \mathrm{cal}$. The last number given represents the plant number. Each block is arranged as a latin square design. Each pot occupied one square foot of space. This layout was not on four benches as shown, but one long continuous bench, east to west (approximately) beginning at left end of top row and ending at right end of bottom row. 

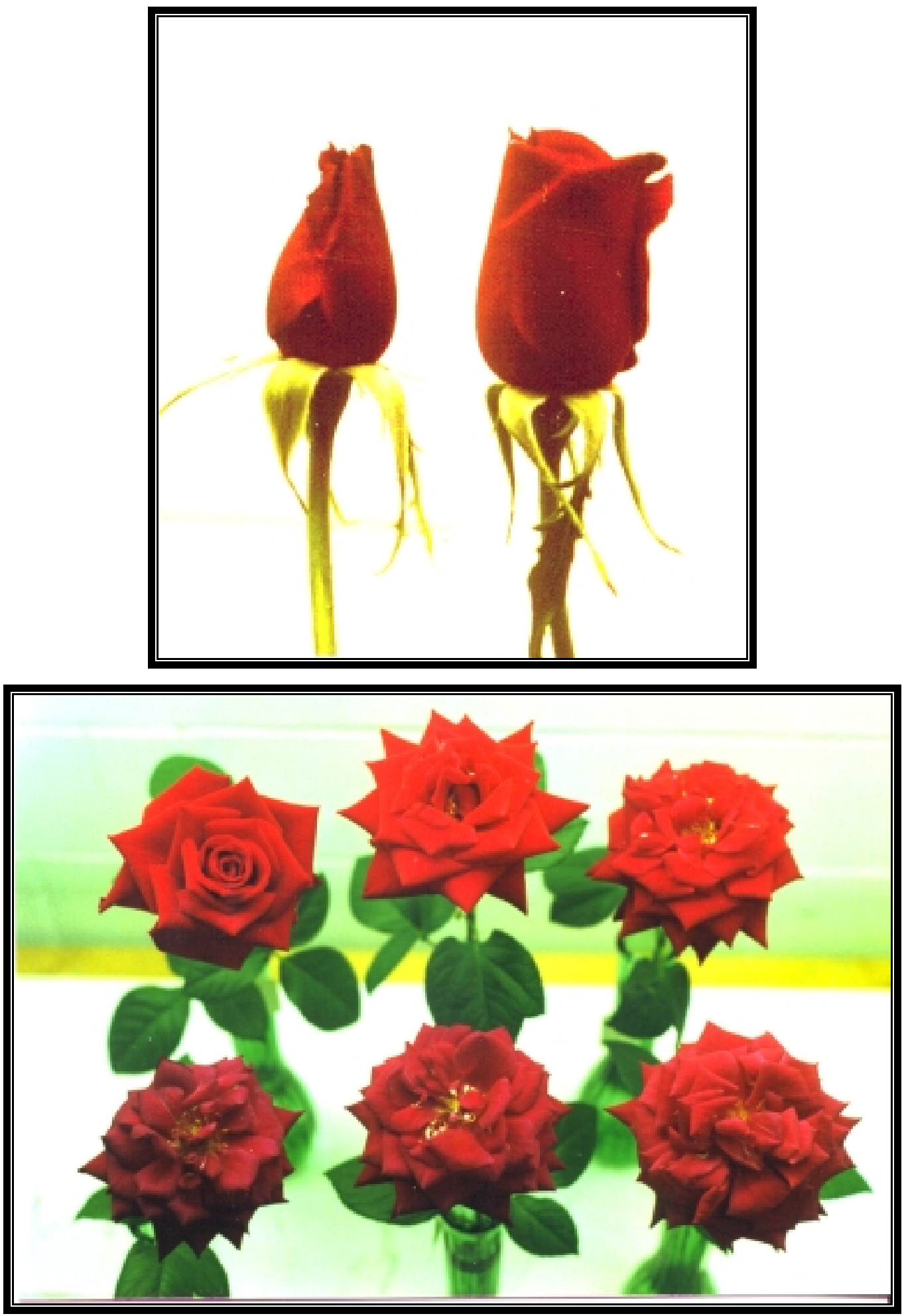

Figure 2.4 The proper stage for cutting is shown on the right. The rose on the left is too tight. Senescing roses at different stages: clockwise from the upper left - 3,5,6,7,8 and 9 days old. 


\begin{tabular}{|c|c|c|c|c|c|}
\hline \multicolumn{3}{|c|}{} & \multicolumn{3}{c|}{ Media parameter after 2 weeks } \\
\hline CBA & P:V & Lime & E.C.(dS/m) & pH & Density $\left(\mathrm{g} / \mathrm{cm}^{3}\right)$ \\
\hline $100 \%$ & 0 & 0 & 0.13 & 9.19 & 0.7848 \\
\hline $75 \%$ & $25 \%$ & 0 & 0.18 & 7.99 & 0.6592 \\
\hline $50 \%$ & $50 \%$ & 0 & 0.15 & 7.28 & 0.4986 \\
\hline $25 \%$ & $75 \%$ & 0 & 0.08 & 6.12 & 0.318 \\
\hline 0 & $100 \%$ & 0 & 0.13 & 4.95 & 0.1121 \\
\hline 0 & $100 \%$ & $11 \mathrm{~g} / \mathrm{l}$ & 0.18 & 7.99 & - \\
\hline 0 & $100 \%$ & $22 \mathrm{~g} / \mathrm{l}$ & 0.11 & 8.09 & - \\
\hline 0 & $100 \%$ & $33 \mathrm{~g} / \mathrm{l}$ & 0.18 & 8.14 & - \\
\hline 0 & $100 \%$ & $66 \mathrm{~g} / \mathrm{l}$ & 0.19 & 8.24 & - \\
\hline 0 & $100 \%$ & $99 \mathrm{~g} / \mathrm{l}$ & 0.16 & 8.19 & - \\
\hline 0 & $100 \%$ & $2.5 \mathrm{~g} / \mathrm{l}$ & - & 5.97 & 0.1135 \\
\hline 0 & $100 \%$ & $3.75 \mathrm{~g} / \mathrm{l}$ & - & 7.00 & 0.1135 \\
\hline 0 & $100 \%$ & $5.0 \mathrm{~g} / \mathrm{l}$ & - & 7.51 & 0.1135 \\
\hline 0 & $100 \%$ & $7.5 \mathrm{~g} / \mathrm{l}$ & - & 7.74 & 0.1135 \\
\hline 0 & $100 \%$ & $10 \mathrm{~g} / \mathrm{l}$ & - & 7.78 & - \\
\hline
\end{tabular}

Table 2.1 Preliminary media incubation study showing the components of each trial mix and the E.C., pH, and density of each mix after two weeks of normal greenhouse conditions and watering. This study was conducted to determine which media mixes would give the desired $\mathrm{pH}$ for our rose-growing media. The $\mathrm{pH}$ was monitored by the pour-through method. "P: $\mathrm{V}$ " indicates a 1:1 mix of peat moss and vermiculite. The lime used in this study was calcitic lime. Density was calculated as the dry weight divided by the wet (fresh) volume. 


\begin{tabular}{|c|c|c|c|c|c|c|}
\hline $\begin{array}{c}\text { Cultivar/ } \\
\text { Media }\end{array}$ & $\begin{array}{c}\text { Crop 1 } \\
\text { Stem Length }\end{array}$ & $\begin{array}{c}\text { Crop 2 } \\
\text { Stem Length }\end{array}$ & $\begin{array}{c}\text { Average } \\
\text { Stem Length }\end{array}$ & $\begin{array}{c}\text { Crop 1 } \\
\text { Bud diameter }\end{array}$ & $\begin{array}{c}\text { Crop 2 } \\
\text { Bud diameter }\end{array}$ & $\begin{array}{c}\text { Average } \\
\text { Bud diameter }\end{array}$ \\
\hline S-1 & 57.3 & 66.5 & 61.9 & 2.65 & 3.15 & 2.9 \\
\hline S-2 & 56.4 & 62.6 & 59.5 & 2.68 & 2.99 & 2.8 \\
\hline S-3 & 55.8 & 66.0 & 60.9 & 2.61 & 2.97 & 2.8 \\
\hline S-4 & 54.1 & 67.0 & 60.6 & 2.62 & 3.22 & 2.9 \\
\hline Average for S & 55.9 & 65.5 & 60.7 & 2.6 & 3.1 & 2.9 \\
\hline O-1 & 68.9 & 59.6 & 64.3 & 2.86 & 2.98 & 2.9 \\
\hline O-2 & 68.9 & 53.4 & 61.2 & 2.75 & 2.93 & 2.8 \\
\hline O-3 & 64.8 & 64.2 & 64.5 & 2.71 & 2.87 & 2.8 \\
\hline O-4 & 68.8 & 62.8 & 65.8 & 2.73 & 3.01 & 2.9 \\
\hline Average for O & 67.9 & 60.0 & 63.9 & 2.8 & 2.9 & 2.9 \\
\hline D-1 & 73.2 & 87.9 & 80.6 & 2.69 & 2.86 & 2.8 \\
\hline D-2 & 78.2 & 87.3 & 82.8 & 2.79 & 2.76 & 2.8 \\
\hline D-3 & 75.4 & 90.0 & 82.7 & 2.78 & 2.82 & 2.8 \\
\hline D-4 & 76.5 & 90.3 & 83.4 & 2.69 & 2.74 & 2.7 \\
\hline Average for D & 75.8 & 88.9 & 82.4 & 2.7 & 2.8 & 2.8 \\
\hline C-1 & 54.6 & 57.8 & 56.2 & 2.46 & 2.43 & 2.4 \\
\hline C-2 & 52.4 & 56.3 & 54.4 & 2.37 & 2.41 & 2.4 \\
\hline C-3 & 54.4 & 60.1 & 57.3 & 2.37 & 2.38 & 2.4 \\
\hline C-4 & 55.1 & 59.5 & 57.3 & 2.39 & 2.41 & 2.4 \\
\hline Average for C & 54.1 & 58.4 & 56.3 & 2.4 & 2.4 & 2.4 \\
\hline
\end{tabular}

\begin{tabular}{|c|c|c|c|c|c|c|}
\hline $\begin{array}{c}\text { Cultivar/ } \\
\text { Media }\end{array}$ & $\begin{array}{c}\text { Crop 1 } \\
\text { Stem Weight }\end{array}$ & $\begin{array}{c}\text { Crop 2 } \\
\text { Stem Weight }\end{array}$ & $\begin{array}{c}\text { Average } \\
\text { Stem Weight }\end{array}$ & $\begin{array}{c}\text { Crop 1 } \\
\text { Flowers/plant }\end{array}$ & $\begin{array}{c}\text { Crop 2 } \\
\text { Flowers/plant }\end{array}$ & $\begin{array}{c}\text { Average } \\
\text { Flowers/plant }\end{array}$ \\
\hline S-1 & 28.4 & 36.3 & 32.4 & 3.1 & 3.3 & 3.2 \\
\hline S-2 & 27.2 & 34 & 30.6 & 4.3 & 3.6 & 4.0 \\
\hline S-3 & 26.3 & 38.3 & 32.3 & 4.1 & 2.8 & 3.5 \\
\hline S-4 & 25.6 & 41.6 & 33.6 & 3.6 & 1.9 & 2.8 \\
\hline Average for S & 26.9 & 37.6 & 32.2 & 3.8 & 2.9 & 3.3 \\
\hline O-1 & 27 & 23.6 & 25.3 & 2.8 & 4.3 & 3.6 \\
\hline O-2 & 28.7 & 20.9 & 24.8 & 3.3 & 5.4 & 4.4 \\
\hline O-3 & 27.9 & 26.6 & 27.3 & 3.8 & 4.9 & 4.4 \\
\hline O-4 & 28.6 & 25.3 & 27.0 & 3 & 4.9 & 4.0 \\
\hline Average for O & 28.1 & 24.1 & 26.1 & 3.2 & 4.9 & 4.1 \\
\hline D-1 & 33.8 & 41.4 & 37.6 & 2.8 & 3.3 & 3.1 \\
\hline D-2 & 38.7 & 40.3 & 39.5 & 3.3 & 3.4 & 3.4 \\
\hline D-3 & 36.7 & 43.1 & 39.9 & 3.8 & 3.3 & 3.6 \\
\hline D-4 & 35 & 41.8 & 38.4 & 3.4 & 3.6 & 3.5 \\
\hline Average for D & 36.1 & 41.7 & 38.9 & 3.3 & 3.4 & 3.4 \\
\hline C-1 & 26 & 24.3 & 25.2 & 5 & 4.8 & 4.9 \\
\hline C-2 & 23.3 & 24 & 23.7 & 5.6 & 4.9 & 5.3 \\
\hline C-3 & 23.6 & 25.3 & 24.5 & 5 & 5.3 & 5.2 \\
\hline
\end{tabular}

Table 2.2 Yields for Crop 1 and Crop 2 roses. Crop 1 was taken in late May; Crop 2 in early September. Every flower from each plant was measured. No significant difference due to media was found for any of the parameters measured. A significant difference was found due to cultivar for all four parameters, and also between crops. Cultivars were affected by crop (season of harvest) in different ways. Explanation of notation for cultivar/media: $S=$ Santa Fe; $\mathrm{O}=$ Pink Osiana; $\mathrm{D}=$ Dakota; $\mathrm{C}=\mathrm{Cara} \mathrm{Mia} ; 1=50 \% \mathrm{CBA} ; 2=25 \% \mathrm{CBA}$; $3=\mathrm{P}: \mathrm{V} / \mathrm{dol}$; and 4=P:V/dol:cal. 


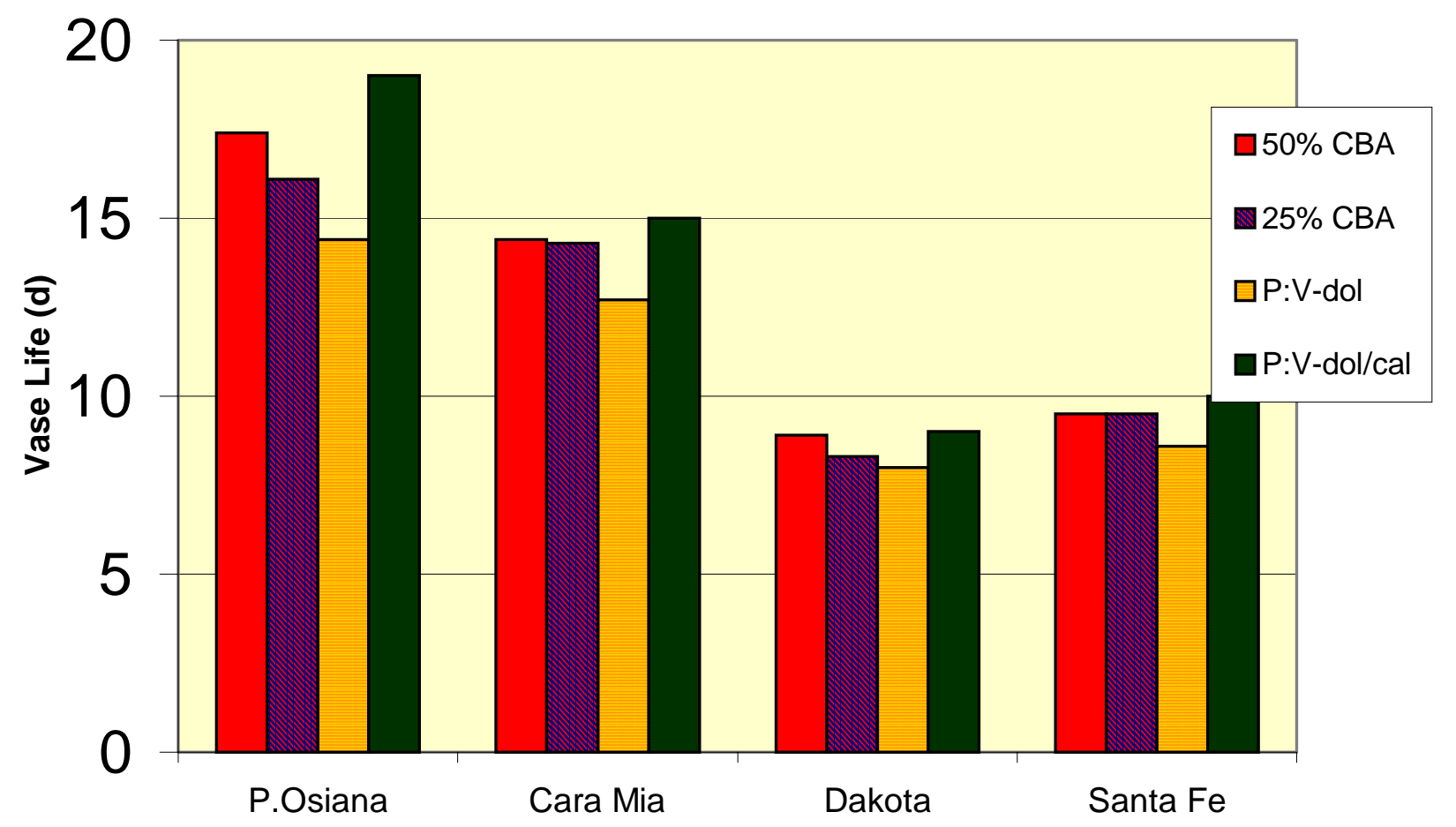

Figure 2.5. Vase life of four cultivars of roses grown in four media. The mean vase life (days) for each media (calculated as the mean of all four cultivars) was: P:V-dol/cal 13.4 a.; 50\% CBA - 12.6 ab.; 25\% CBA - 12.1 b.; and P:V-dol - 10.9 c. Different letters beside the means indicate statistically significant differences at the $\mathrm{p}=0.05$ level. 


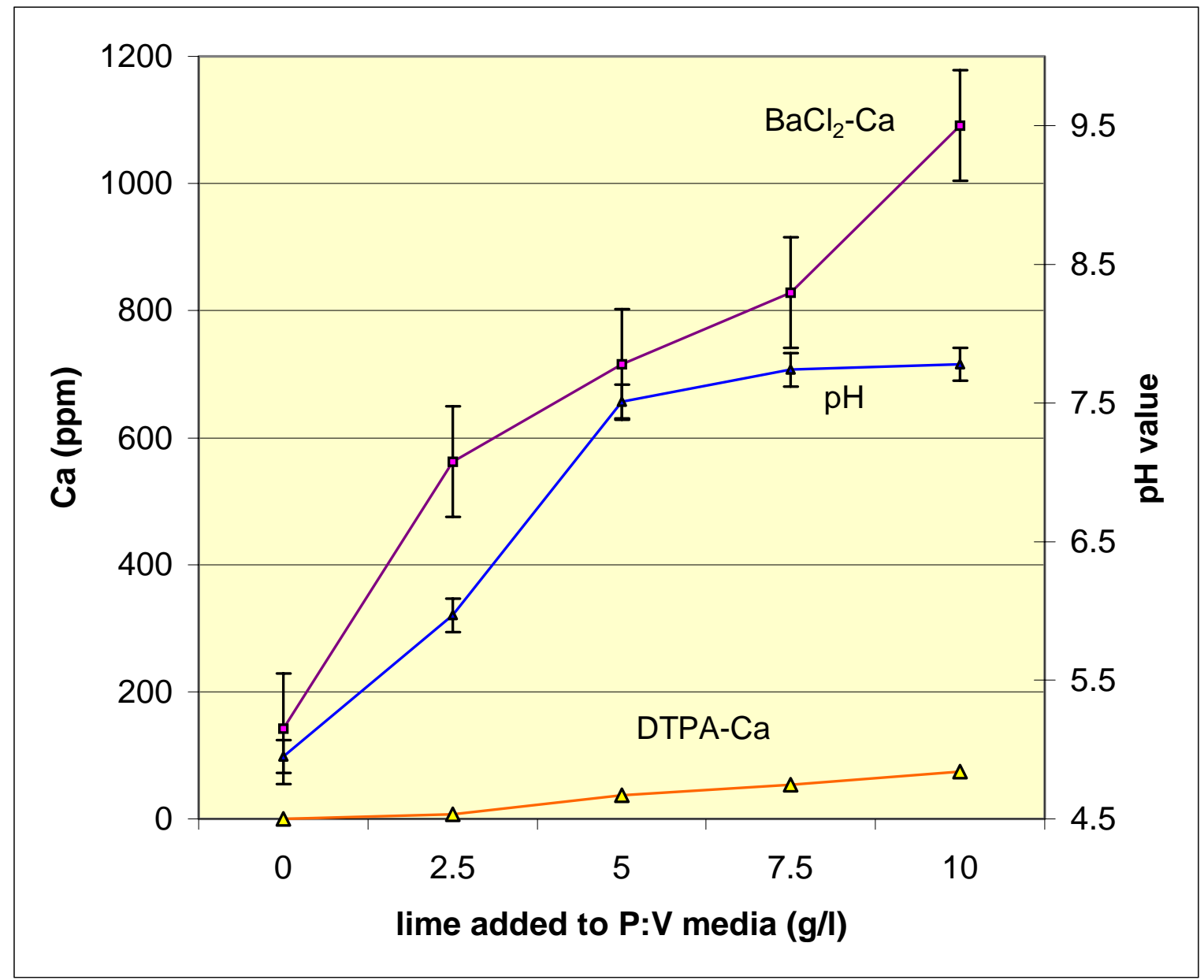

Figure 2.6 Calcium content and $\mathrm{pH}$ of the $\mathrm{P}: \mathrm{V}$ media from a preliminary incubation study. All media were peat:vermiculite (1:1) with the given amount of lime added. Measurements were taken after two weeks in the greenhouse under normal conditions and watering. Calcium was quantified using two different tests as explained in the text. Error bars represent $+/-2$ s.e. 


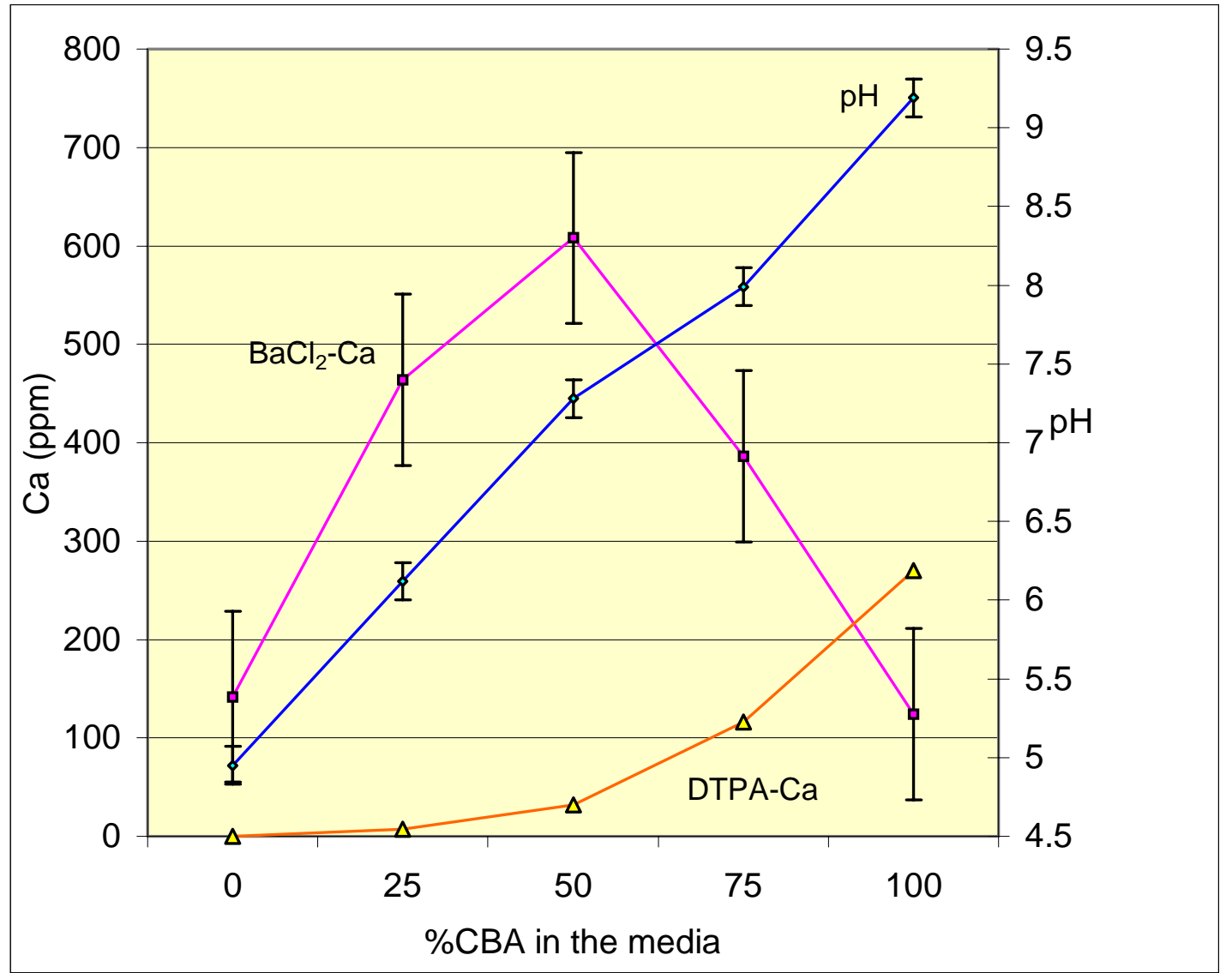

Figure 2.7 Calcium content and $\mathrm{pH}$ of the CBA media from a preliminary incubation study. All media were made with the given amount of CBA and the remainder of the media was made of peat:vermiculite (1:1). Measurements were taken after two weeks in the greenhouse under normal conditions and watering. Calcium was quantified using two different tests as explained in the text. Error bars represent $+/-2$ s.e. 

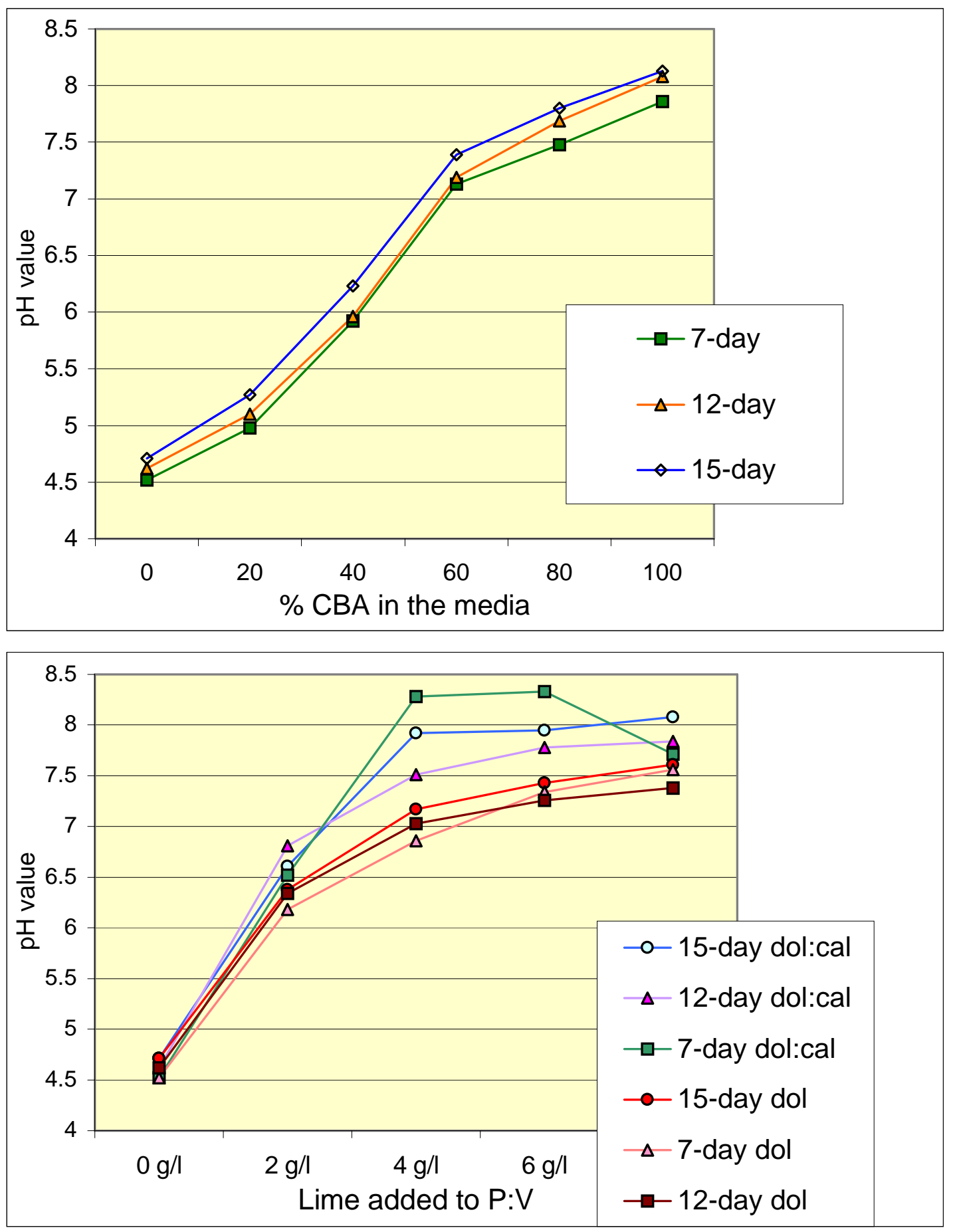

Figure 2.8 The $\mathrm{pH}$ of $\mathrm{CBA}$ and $\mathrm{P}: \mathrm{V}$ media from a preliminary incubation study. Measurements were taken after two weeks in the greenhouse under normal conditions and watering. $\mathrm{pH}$ was measured by the pour-through method. In the lower graph, dol=dolomitic lime and dol:cal= dolomitic and calcitic lime (1:1). 


\begin{tabular}{|c|c|c|c|c|c|c|c|c|}
\hline Media & $\mathrm{pH}$ & $\mathrm{N}(\mathrm{ppm})$ & $\mathrm{P}(\mathrm{ppm})$ & $\mathrm{K}(\mathrm{ppm})$ & $\mathrm{Ca}(\mathrm{ppm})$ & $\mathrm{Mg}(\mathrm{ppm})$ & $\mathrm{Mn}(\mathrm{ppm})$ & $\mathrm{B}(\mathrm{ppm})$ \\
\hline $50 \% \mathrm{CBA}$ & $6.8 \mathrm{a}$ & 20 & 7 & 55 & 116 & 45 & $6.76 \mathrm{a}$ & $.53 \mathrm{a}$ \\
\hline $25 \% \mathrm{CBA}$ & $5.5 \mathrm{~b}$ & 89 & 7 & 86 & 83.5 & 78 & $5.03 \mathrm{~b}$ & $.44 \mathrm{ab}$ \\
\hline $\mathrm{P}: \mathrm{V} / \mathrm{dol}$ & $6.5 \mathrm{a}$ & 70 & 4 & 75 & 64 & 97 & $4.22 \mathrm{~b}$ & $.30 \mathrm{bc}$ \\
\hline P:V/dol:cal & $6.8 \mathrm{a}$ & 67 & 3 & 76 & 85 & 82 & $2.89 \mathrm{~b}$ & $.25 \mathrm{c}$ \\
\hline
\end{tabular}

Table 2.3. DTPA media analysis taken for Crop 1 roses. For $\mathrm{Mn}$ and $\mathrm{B}$, different letters after the number means that the values are significantly different at the $p=0.05$ level. All nutrient values are given as ppm. 


\section{Discussion}

Yield was not affected in a negative way by CBA. Therefore, unless postharvest performance is negatively impacted, CBA may be a suitable media component for growing roses. Similar yield results were found by Hartley-Butler (1993).

One of the most significant findings of this project is that roses grown in the two high-calcium media had longer vase lives than the roses from the low-calcium media. Especially significant is the finding that roses from media with dolomitic:calcitic lime (1:1) had significantly longer vase lives than roses grown in the same media when the lime was all dolomitic. Calcitic lime has more calcium in it than dolomitic (see Table A2.1 in the Appendix). Often, growers use dolomitic lime exclusively. It has been recommended as a good source of magnesium as well as calcium (Nelson, 1998). The results presented here suggest that adding calcitic lime has a positive effect on vase life.

An unexplained reaction appears to occur in CBA media that contains more than 50\% CBA (Figure 2.7). While we can assume that these high CBA media actually contain more calcium, less of it is extractable with $\mathrm{BaCl}_{2}$-TEA. This may have to do with the low number of exchange sites on CBA. As the media approaches $100 \% \mathrm{CBA}$, the cation exchange capacity of the media may decrease and barium would be expected to displace less $\mathrm{Ca}$. The form of $\mathrm{Ca}$ in the media may also be playing a part in this reaction. Since the $\mathrm{pH}$ of this media was found to rise above 8.2, it is likely that Ca oxide is present. 


\section{Chapter 3 Color and Visual Assessment}

\section{Introduction}

In the present study of postharvest quality of roses, measurements were made on several physical and biochemical parameters, such as ethylene production, membrane leakage, dry and fresh weight, and calcium content. This chapter, however, is a report of the data collected on the visual quality of the roses after harvest. Flower petals and leaves were monitored for color changes as senescence progressed. Also, a panel of judges rated the appearance and scent of the roses. Such an assessment is important since the economic value of roses depends upon their perceived beauty and scent.

Anthocyanins are the major pigments responsible for red color in roses (Gutterson, 1995). These pigments can cause petals to appear orange, red, pink, purple or blue depending on the copigmentation that occurs. Copigmentation is the interaction of anthocyanin with flavenoids and/or other compounds such as metals, alkaloids and polysaccharides. The process is affected by $\mathrm{pH}$ and temperature (Mazza and Brouillard, 1990). [This mechanism accounts for variation in color tone in roses but is not thought to be the mechanism in apples (Lancaster et al., 1994).] Most likely, the level of pigment present also affects color, as it does in Pelargonium (Mitchell et al., 1998).

As some roses senesce, their petals change color. This color change may decrease the aesthetic value of the flower and may be used as a measurable parameter of senescence. Color changes can be caused by biochemical changes in the pigments themselves, in the degree of copigmentation, and by changes in the petal $\mathrm{pH}$. Most noteworthy are "bluing" and/or blackening of red rose petals (Halevy and Mayak, 1979). Bluing is thought to occur due to a $\mathrm{pH}$ change that affects the degree of copigmentation of anthocyanins (Lancaster et al., 1994). The $\mathrm{pH}$ of the vacuole increases, it is thought, as proteins break down during senescence (Halevy and Mayak, 1979). Blackening may occur due to oxidation of flavones, leucoanthocyanins and other phenols. 


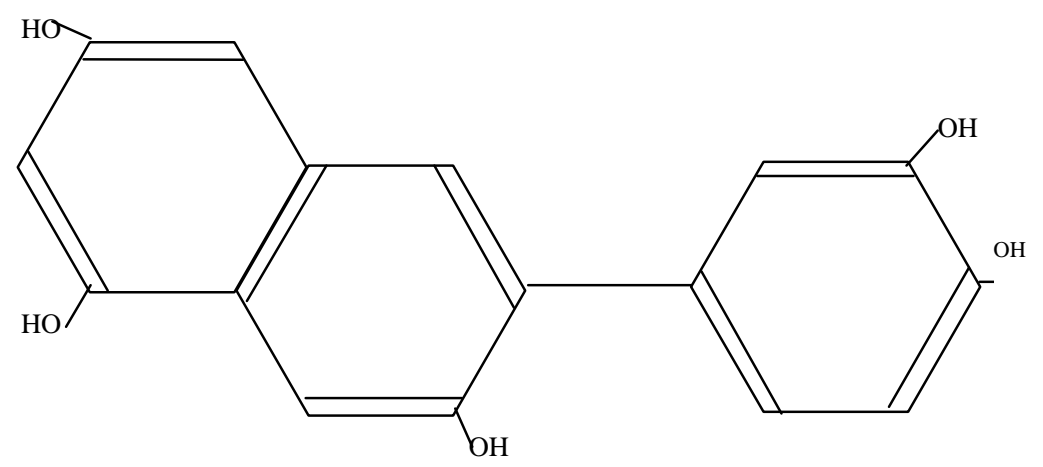

-the anthocyanin Cyanidin (Harborne, 1988)

A chroma meter gives researchers a way to quantitatively and nondestructively measure changes in color. Three parameters of light are measured; brightness $\left(\mathrm{L}^{*}\right)$, the red-to-green quality $\left(a^{*}\right)$ and the yellow-to-blue quality $\left(b^{*}\right)$. From $a^{*}$ and $b^{*}$, two other quantities can be calculated - chroma and hue. Chroma is often explained as "saturation" of color - how intense, pure or vivid it is. Hue is mathematically the angle from $0^{0}$ as shown on the diagram below. It is the visual sensation or tone.

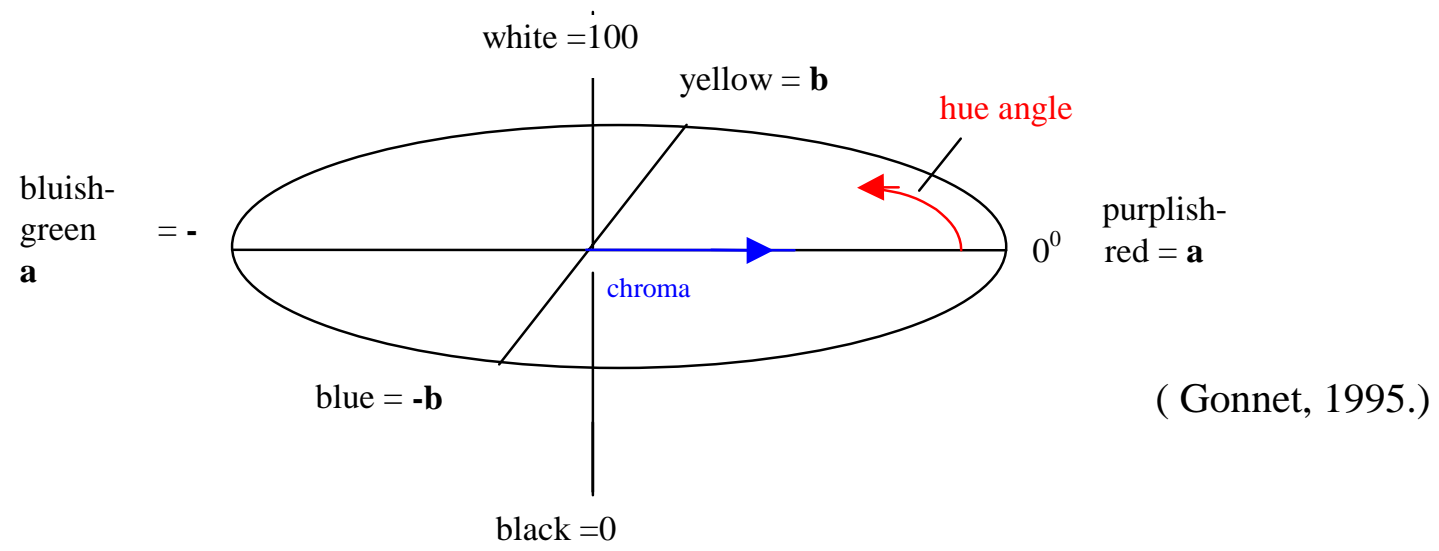

Singha et al. (1991) have used chromaticity to estimate anthocyanin levels in apples. To get a good fit for the regression, they used complex models (for example, $\mathrm{L}\left(\mathrm{a} * / \mathrm{b}^{*}\right)^{2}$ with separate equations for each strain gave $\mathrm{R}^{2}=0.81$ ). Their data appears to show a nonlinear, logarithmic relationship between chromatic value and anthocyanin content. D'Sousa et 
al. (1992) used chromaticity to estimate lycopene concentrations in tomatoes. The best $\mathrm{R}^{2}$ value was achieved by using $(\mathrm{a} * / \mathrm{b} *)^{2}$.

Chroma meter values have also been used to estimate the quantity of chlorophyll in leaves of apple, grape and peach (Singha and Townsend, 1989). Chlorophyll content was correlated with chroma (with an $\mathrm{R}^{2}$ value of 0.82-0.95 depending on species). A quadratic function fit best. Steet and Tong (1996) used -a* to follow the decrease in the green color of peas and this correlated with chlorophyll degradation. Negative a* values were used because as a surface becomes more "green", the a* value becomes more negative.

\section{Materials and Methods}

During the vase life, changes in petal color were monitored for Rosa x hybrida cvs. Dakota, Cara Mia, Pink Osiana and Santa Fe. The roses used for this study were the first crop taken from the bushes and the same set of flowers that were used for the longevity study (Chapter 2). Cutting was done from May 18 to June 18, 1998. See "Materials and Methods" in Chapter 2 for the cutting and treatment methods used on these roses. The first rose harvested from each bush was used, giving 8 roses for each cultivar/media combination.

Leaf color was monitored on Dakota and Cara Mia roses that were cut during the fourth crop - August 21 to September 16, 1999. These roses were treated the same way as described above. Six roses of each cultivar/media combination were used.

Flower petal color and leaf color were measured daily from time of cutting until the end of vase life. A Minolta Chroma meter CR-200 was used. L*, a* and b* were recorded. Chroma and hue were calculated according to the following formulae:

Chroma $=\left(a^{2}+b^{2}\right)^{0.5} ;$ and Hue $=\arctan (b \div a)$. On each flower, the third petal from the outside was measured at the center of the outer surface. For leaf color, the terminal leaflet of the uppermost three-leaflet leave was measured on the upper surface in the center. 
A panel of judges did a subjective assessment of the roses. All roses were judged on the first day after cutting. Each day for four days, two groups of four roses each were presented to four judges. One group was Cara Mia; the other was Dakota. Each group contained one rose from each of the four media. These were randomly ordered. The judges were given a questionnaire asking them to rate each flower on a scale of one to ten for 11 different qualities. These included 9 visual quantities and 2 scent quantities. A copy of the questionnaire can be found in the Appendix (Figure A-3.1). This list of visual qualities was adapted from the recommended rose judging procedure (Pi Alpha Xi Judging Standards Committee, 1983). An explanatory sheet that described "bullhead" and "peanut" was posted in the judging area. In all, four flowers of each cultivar/media combination were evaluated by each of the four judges.

For analysis of the subjective assessment, the 9 visual quality ratings were summed for each rose for each judge. The two scent ratings were averaged.

\section{Statistical Analysis}

Petal Color was analyzed using a simple GLM procedure in SAS with cultivar and media as the main effects and including a plant within media term and an interaction term. Separation of means was done using an LSD test in SAS.

Leaf color was analyzed using the GLM procedure in SAS as a split-split plot with cultivar as the main plot treatment in blocks. Media was a subplot treatment arranged in a Latin square and day was a sub-subplot treatment. The model used here is the same as that used for ethylene production and is shown in Appendix Figure A.4.3.

\section{Results}

\section{Petal Color}

Each of the four rose cultivars followed a characteristic pattern of color change over the course of their vase lives. These patterns of color change, averaged over all four media, are reported in Figures 3.1, 3.2, 3.3, 3.4, and 3.5. From these graphs, the overall pattern of color change can be described. For example, Cara Mia could be described as 
follows: the red quality ( $\mathrm{a}^{*}$ ) of the petals first increases as the rose expands, then decreases. The yellow quality $\left(b^{*}\right)$ decreases throughout the vase life, as does the intensity of color (chroma).

Differences due to media were of interest. Two significant effects due to media were found. These were overall hue in Cara Mia and the pattern of change of hue in Pink Osiana.

Hue, $a^{*}$ and $b^{*}$ for Cara Mia are shown in Table 3.1. Cara Mia roses grown in $50 \%$ CBA had an overall hue that was lower than roses grown in the other three media. This indicates that these 50\% CBA roses tended more toward the blue region. It should be noted that this difference was not noticeable to the eye.

Hue for Pink Osiana changed differently over the vase life depending on media (Figure 3.6). Pink Osiana roses from 50\% CBA had a lower hue from the beginning of their vase lives, while for roses from the other three media, hue began high (at the time of cutting) and then declined as vase life progressed. In terms of color, this means that Pink Osiana had a green tinge to it at the time of cutting and became pinker as it opened. Roses from 50\% CBA had developed this pinker color earlier - by the time of cutting.

\section{Leaf Color}

Over the course of the vase life, no visibly noticeable change in the green color of the leaves was observed. However, quantitative data from the Chroma meter showed that the color was changing to a measurable extent. The following results were obtained after statistical analysis:

$L^{*}$, a measure of brightness, decreased over the vase life for both Cara Mia and Dakota leaves. The decrease occurred at the same rate for both cultivars. Dakota had a higher $\mathrm{L}^{*}$ value overall. No difference was found between roses grown in the different media. Figure 3.7 shows these changes.

The measure of red-to-green (-a*), decreased over the vase life (the leaves became less green). This decrease occurred faster in Cara Mia, but Cara Mia began with a higher (greener) $-\mathrm{a}^{*}$ value (Figure 3.8). A statistically significant media effect was also found for $-\mathrm{a}^{*}$ (Figure 3.9). Media 4 roses (P:V / dol:cal) maintained the highest -a* value of the 
four media. The graph shows data for the first seven days in the vase. After this point, data is not complete because an increasing number of roses had ended their vase lives.

The measure of yellow-to-blue $\left(b^{*}\right)$, decreased over the vase life. This decrease is more rapid for Cara Mia than for Dakota, but overall, these two cultivars do not differ with respect to $b^{*}$ (Figure 3.10). (Note - no overall difference occurs because in Cara Mia, b* starts out higher (more yellow) and ends lower.) A significant media effect was also found (Figure 3.11). Media 4 roses (P:V / dol:cal) maintained the highest $\mathrm{b}^{*}$ value of the four media.

The chroma (intensity) of the leaves of both cultivars decreased over the vase life, with the rate of decrease being greater in Cara Mia roses (Figure 3.12). Media had a significant effect on chroma. As with $b^{*}$ values, media 4 roses showed the highest chroma levels of the four media.

The hue of both cultivars increased over the vase life (Figure 3.13) and this increase occurred faster in Cara Mia than Dakota. No media effect was found.

\section{Subjective Analysis}

With respect to visual assessment by a panel of judges, no significant difference was found between roses grown in different media. However, the judges rated Cara Mia significantly higher than Dakota. Out of a total of 90 possible points, Cara Mia and Dakota were given an average rating of 76.4 and 69.5, respectively (Table 3.2). No significant difference in scent assessment was found due to media or variety. On a scale of 1-10, Cara Mia's scent was rated 6.2 and Dakota's was 5.5 (Table 3.3). 


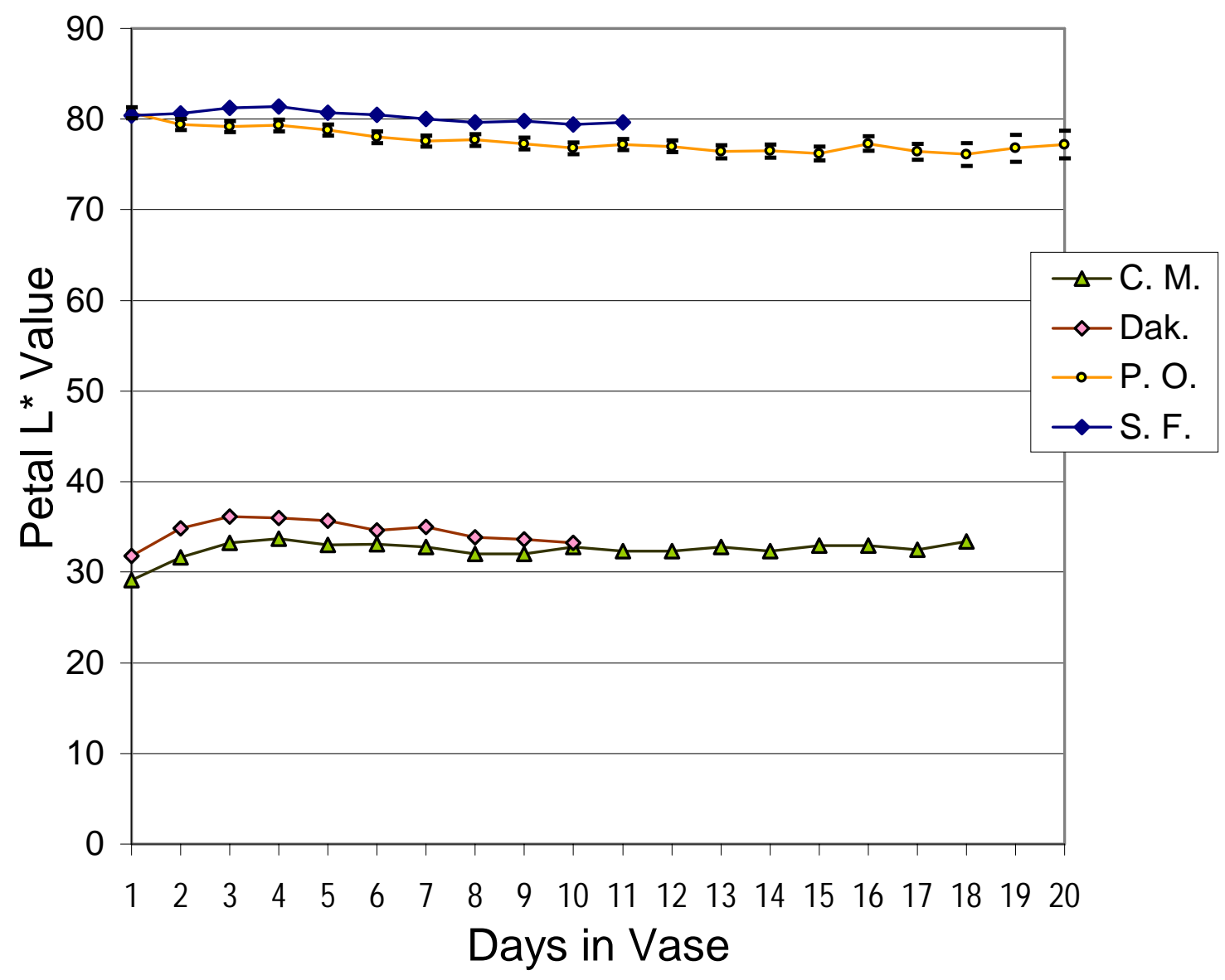

Figure 3.1 L* values for petals of Cara Mia, Dakota, Pink Osiana and Santa Fe roses over their vase lives. Error bars are shown for Pink Osiana (+/- 2 s.e.). Error bars for the other three cultivars were smaller and are not shown. 


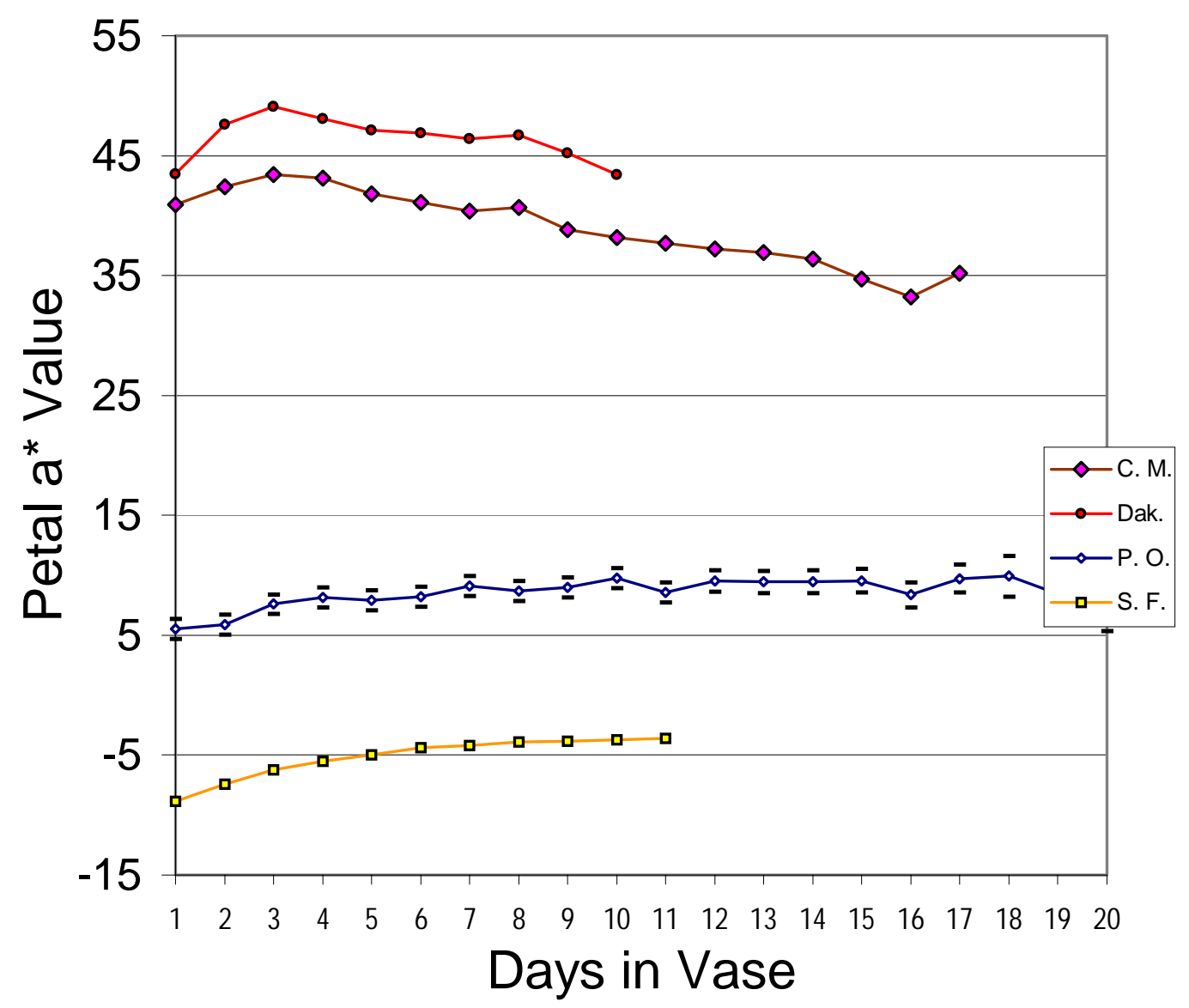

Figure 3.2 a* values for petals of Cara Mia, Dakota, Pink Osiana and Santa $\mathrm{Fe}$ roses over their vase lives. Error bars are shown for Pink Osiana (+/- 2 s.e.). Error bars for the other three cultivars were smaller and are not shown. 


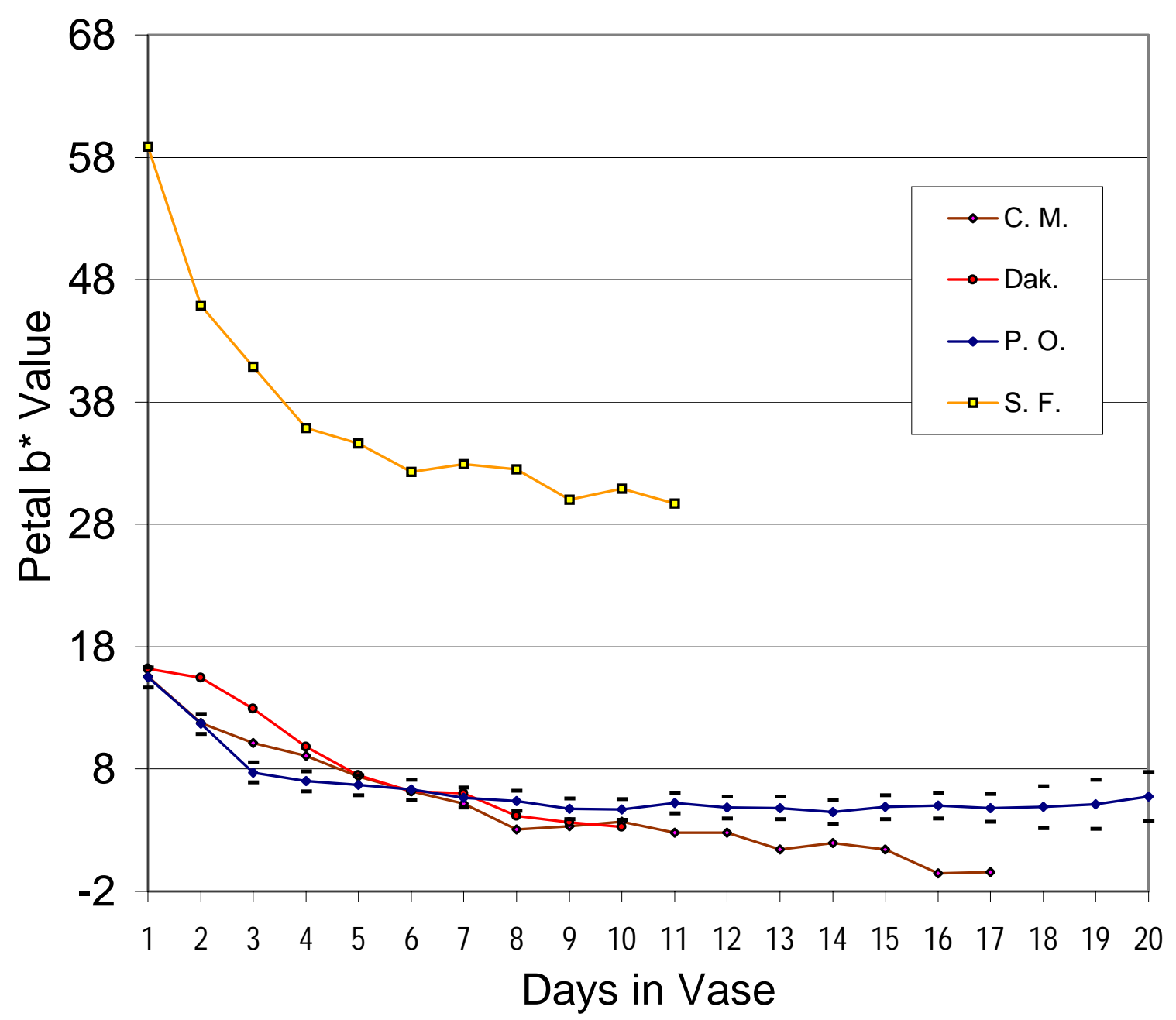

Figure 3.3 $b^{*}$ values for petals of Cara Mia, Dakota, Pink Osiana and Santa Fe roses over their vase lives. Error bars are shown for Pink Osiana (+/- 2 s.e.). Error bars for the other three cultivars were smaller and are not shown. 


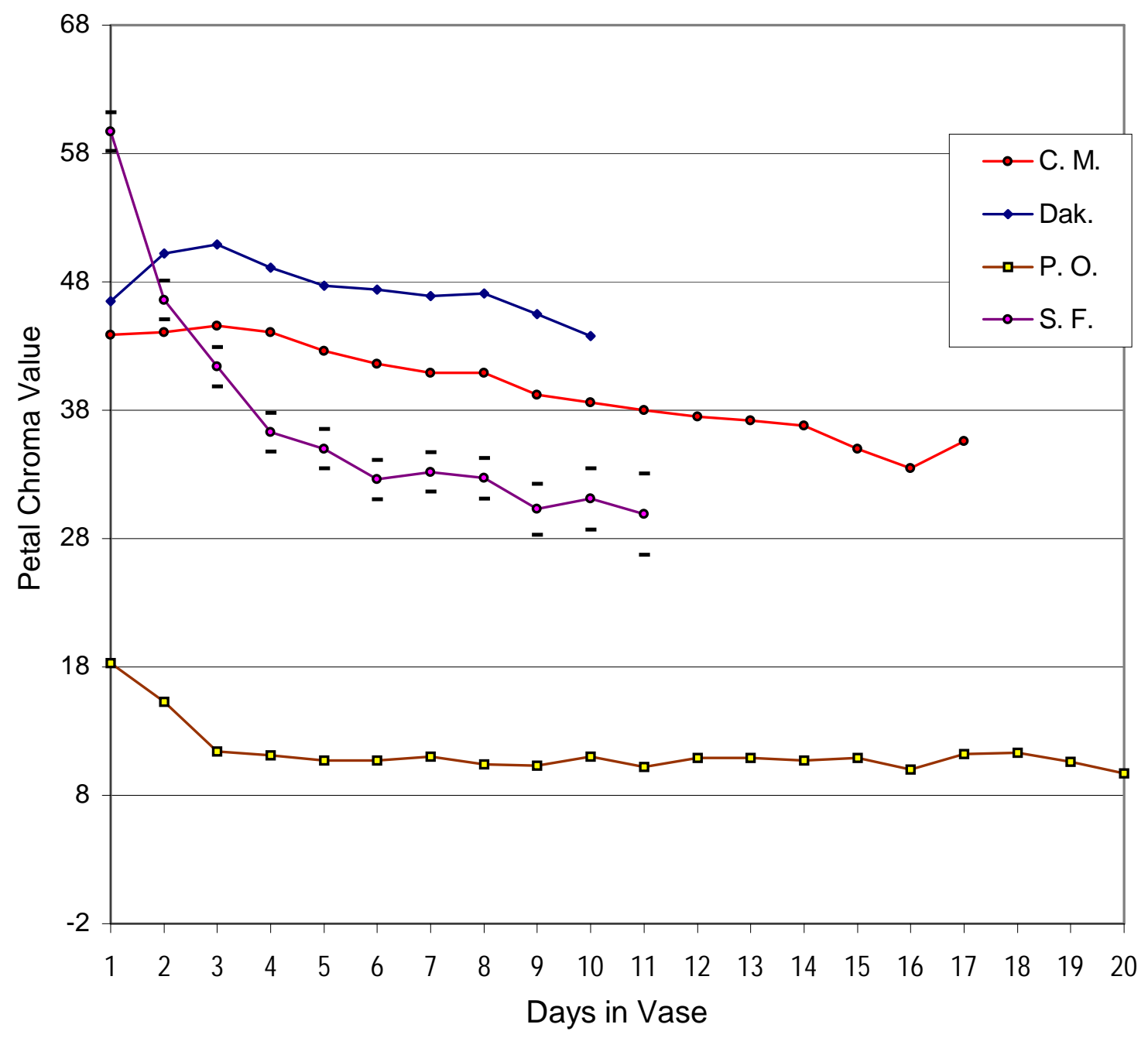

Figure 3.4 Chroma values for petals of Cara Mia, Dakota, Pink Osiana and Santa Fe roses over their vase lives. Error bars are shown for Santa Fe (+/- 2 s.e.). Error bars for the other three cultivars were smaller and are not shown. 


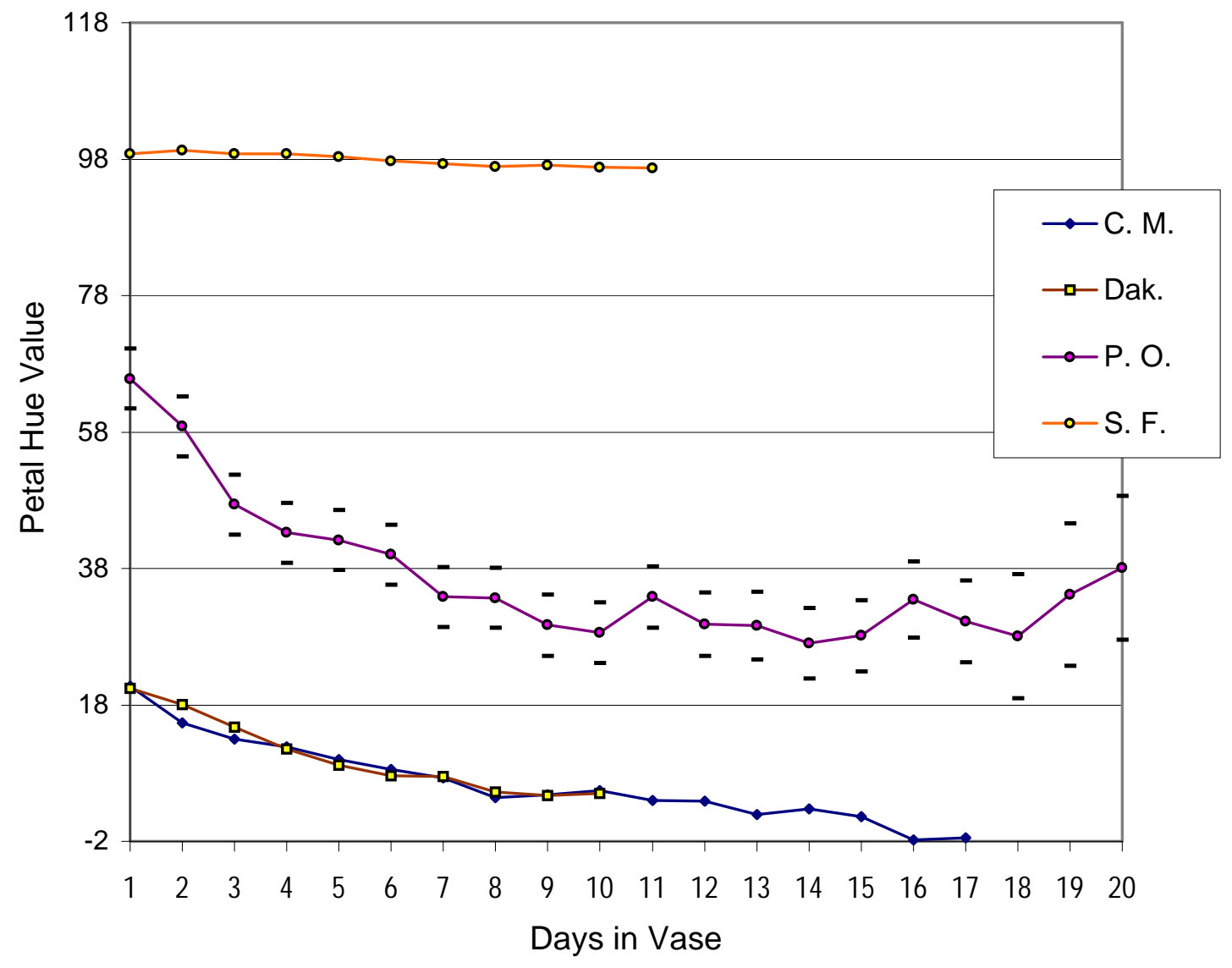

Figure 3.5 Hue values for petals of Cara Mia, Dakota, Pink Osiana and Santa Fe roses over their vase lives. Error bars are shown for Pink Osiana (+/- 2 s.e.). Error bars for the other three cultivars were smaller and are not shown. 


\begin{tabular}{|l||c|c|c|}
\hline \multicolumn{1}{|c||}{ Media } & Hue & $\mathbf{a}^{\boldsymbol{*}}$ & $\mathbf{b}^{\boldsymbol{*}}$ \\
\hline \hline $50 \% \mathrm{CBA}$ & $3.95 \mathrm{a}$ & $3.30 \mathrm{a}$ & $38.21 \mathrm{a}$ \\
\hline $25 \% \mathrm{CBA}$ & $7.15 \mathrm{~b}$ & $5.33 \mathrm{a}$ & $39.16 \mathrm{a}$ \\
\hline $\mathrm{P}: \mathrm{V} / \mathrm{dol}$ & $7.89 \mathrm{~b}$ & $5.89 \mathrm{a}$ & $39.37 \mathrm{a}$ \\
\hline $\mathrm{P}: \mathrm{V} /$ dol $:$ cal & $7.45 \mathrm{~b}$ & $5.44 \mathrm{a}$ & $39.08 \mathrm{a}$ \\
\hline
\end{tabular}

Table 3.1 Hue, $a^{*}$ and $b^{*}$ for Cara Mia roses over the course of their vase lives. Different letters indicate a significant difference at the $\mathrm{p}=0.05$ level. 


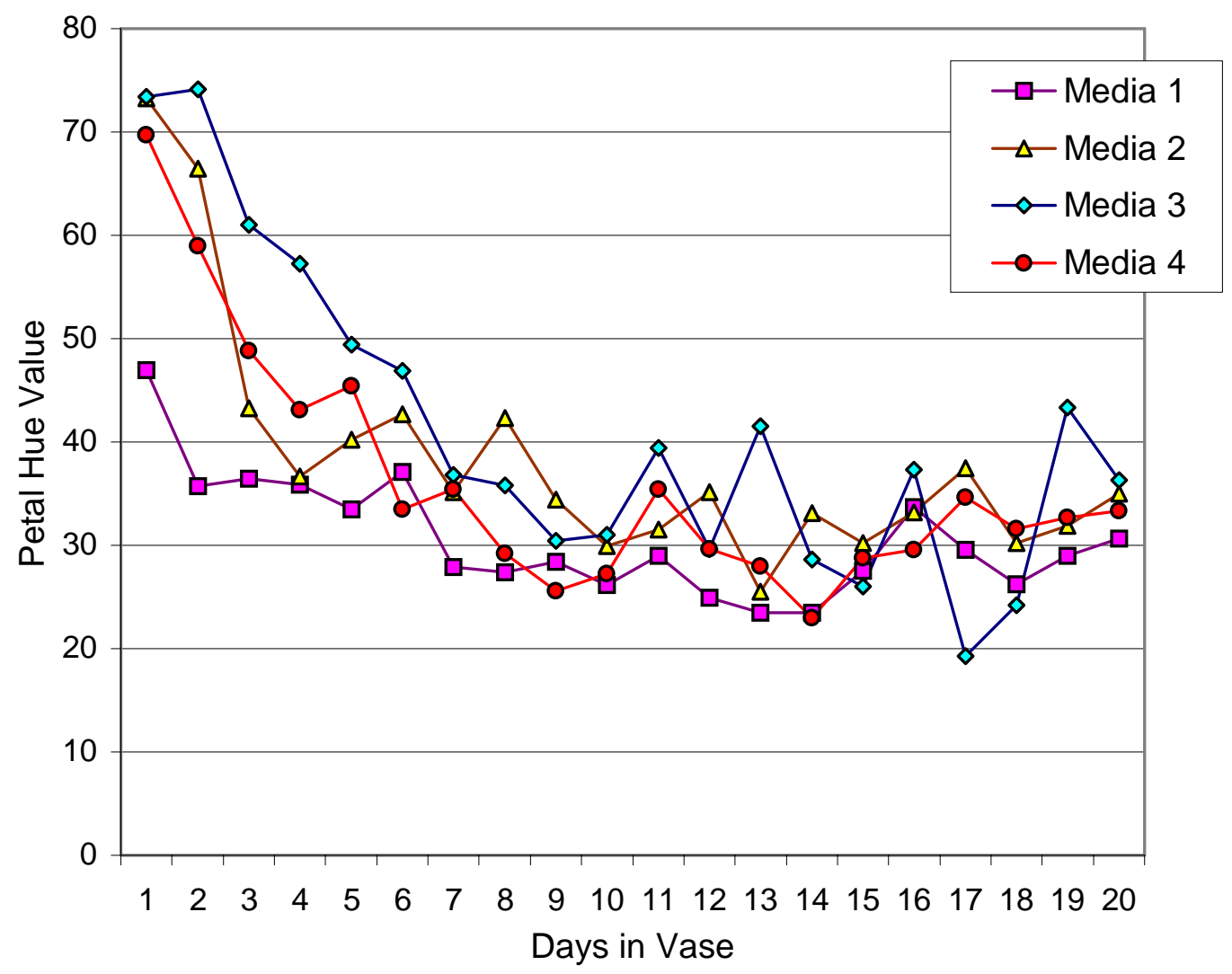

Figure 3.6 Hue values for Pink Osiana rose petals grown in four media. Media $1=50 \%$ CBA; media 2 is $25 \%$ CBA; media 3 is $\mathrm{P}: \mathrm{V}$ with dol; and media 4 is $\mathrm{P}: \mathrm{V}$ with dol:cal. Media 1 has a significantly different curve than the other three media, exhibiting a lower hue from the beginning of the vase life. See text for an interpretation. 


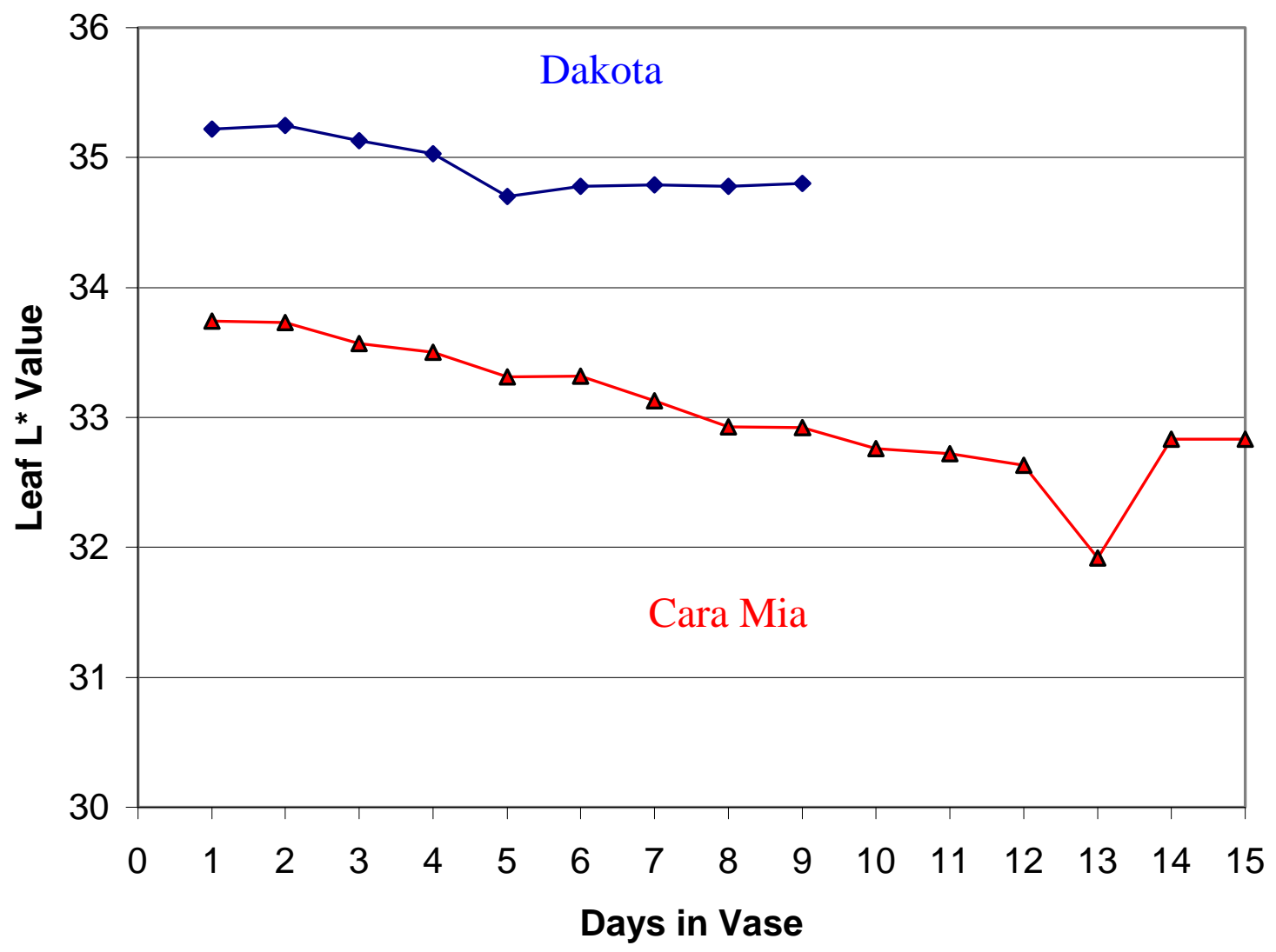

Figure 3.7 L* value of the leaves of Cara Mia and Dakota roses over the course of the vase life. M. S. error $=.378$. There is significant evidence that $\mathrm{L}^{*}$ decreases over the vase life for both cultivars, that this decrease happens at the same rate for both cultivars, and that Dakota has a higher $\mathrm{L}^{*}$ value than Cara Mia overall. 


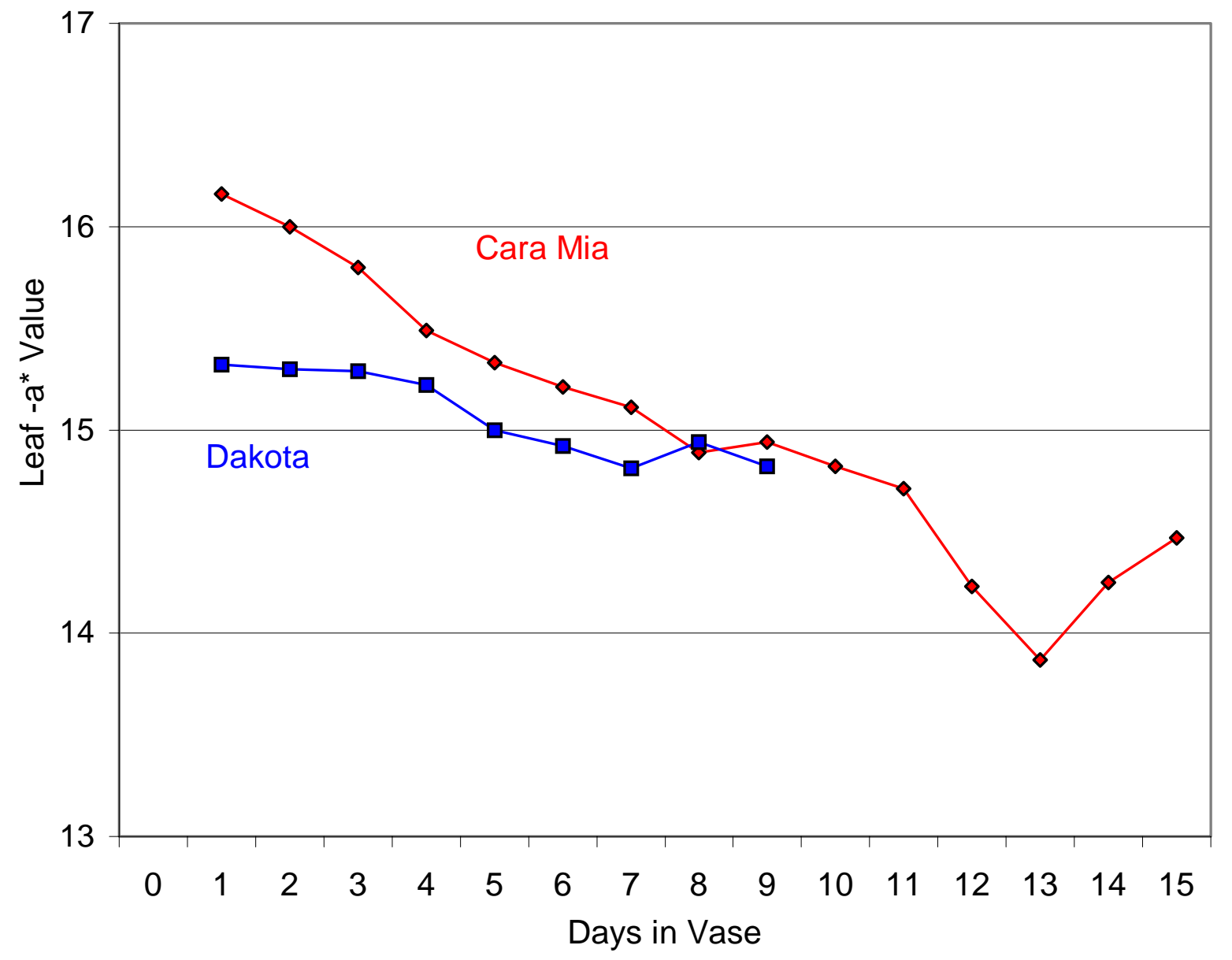

Figure 3.8 Leaf greenness (-a*) values for Cara Mia and Dakota roses over the course of the vase life. M. S. error $=.1974$. There is significant evidence that greenness $\left(-\mathrm{a}^{*}\right)$ is decreasing over the vase life for both cultivars, that the decrease is faster for Cara Mia, and that Cara Mia has a higher $-\mathrm{a}^{*}$ values for the first three days of the vase life. 


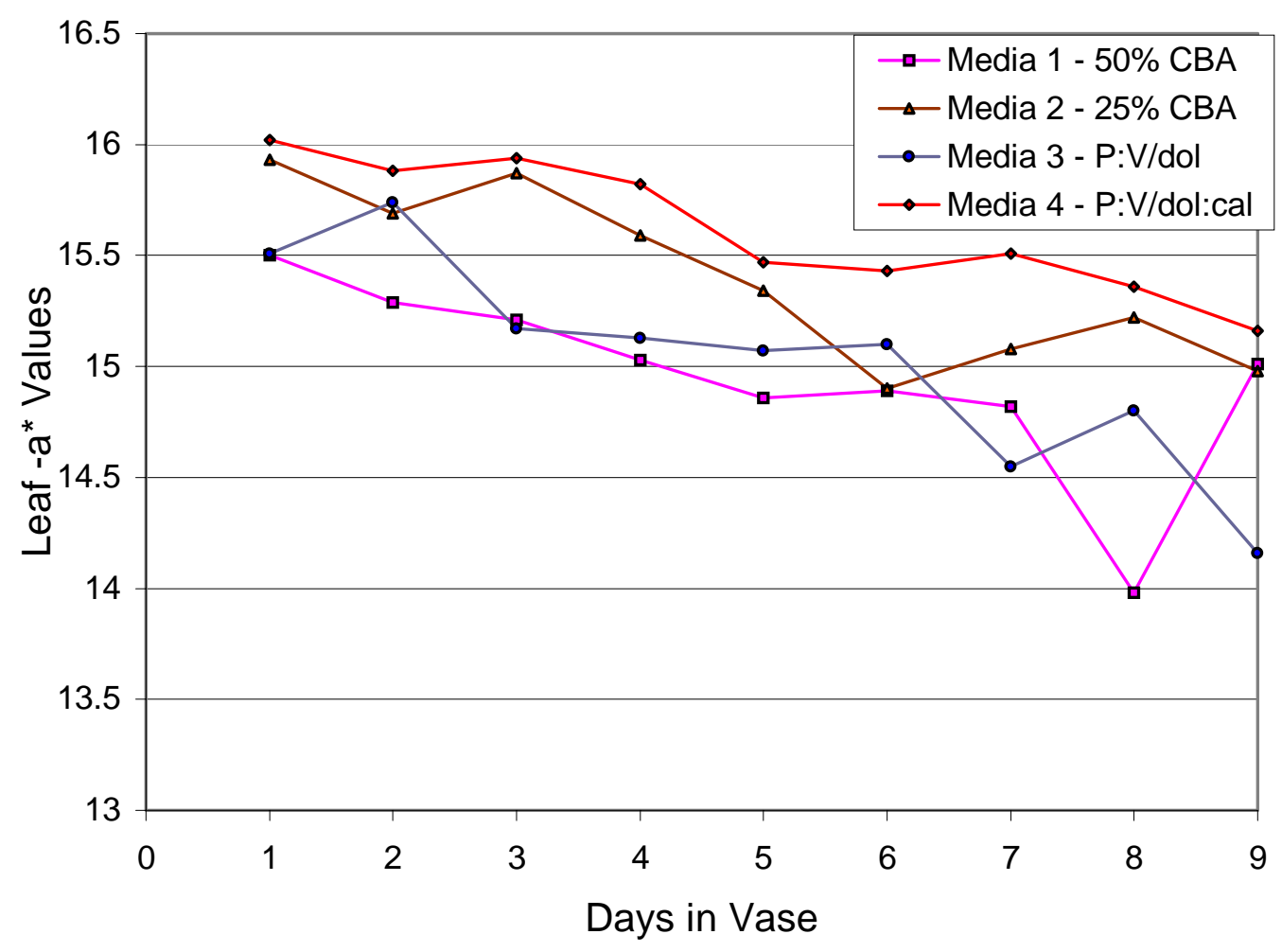

Figure 3.9 Leaf $-\mathrm{a}^{*}$ values for roses grown in the four media over the course of the vase life. M. S. error $=.1974$. There is significant evidence that $-\mathrm{a}^{*}$ is affected by media. 


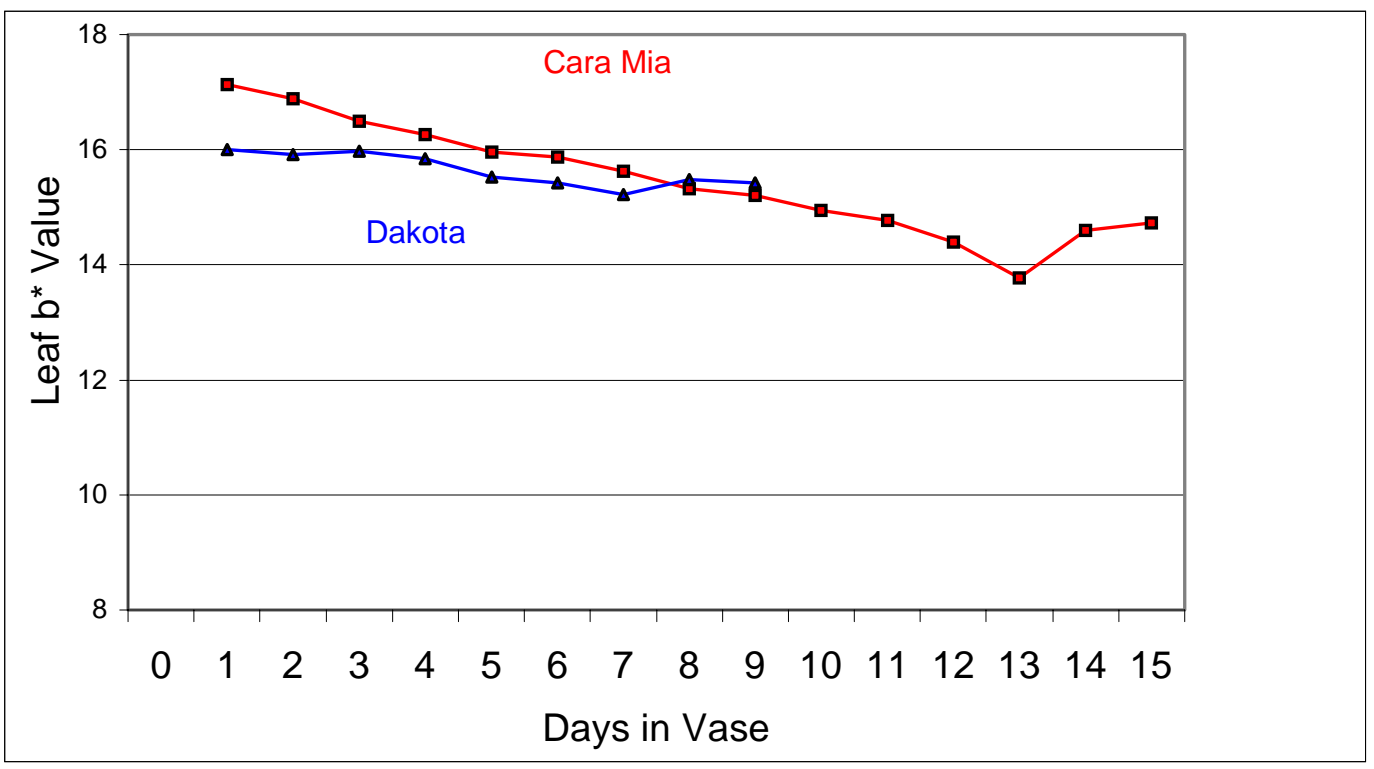

Figure 3.10 Leaf $b^{*}$ values for Cara Mia and Dakota roses as they senesce. There is significant evidence that $b^{*}$ is decreasing for both cultivars as vase life progresses, and that this decrease is more rapid for Cara Mia. M. S. error $=.4806$.

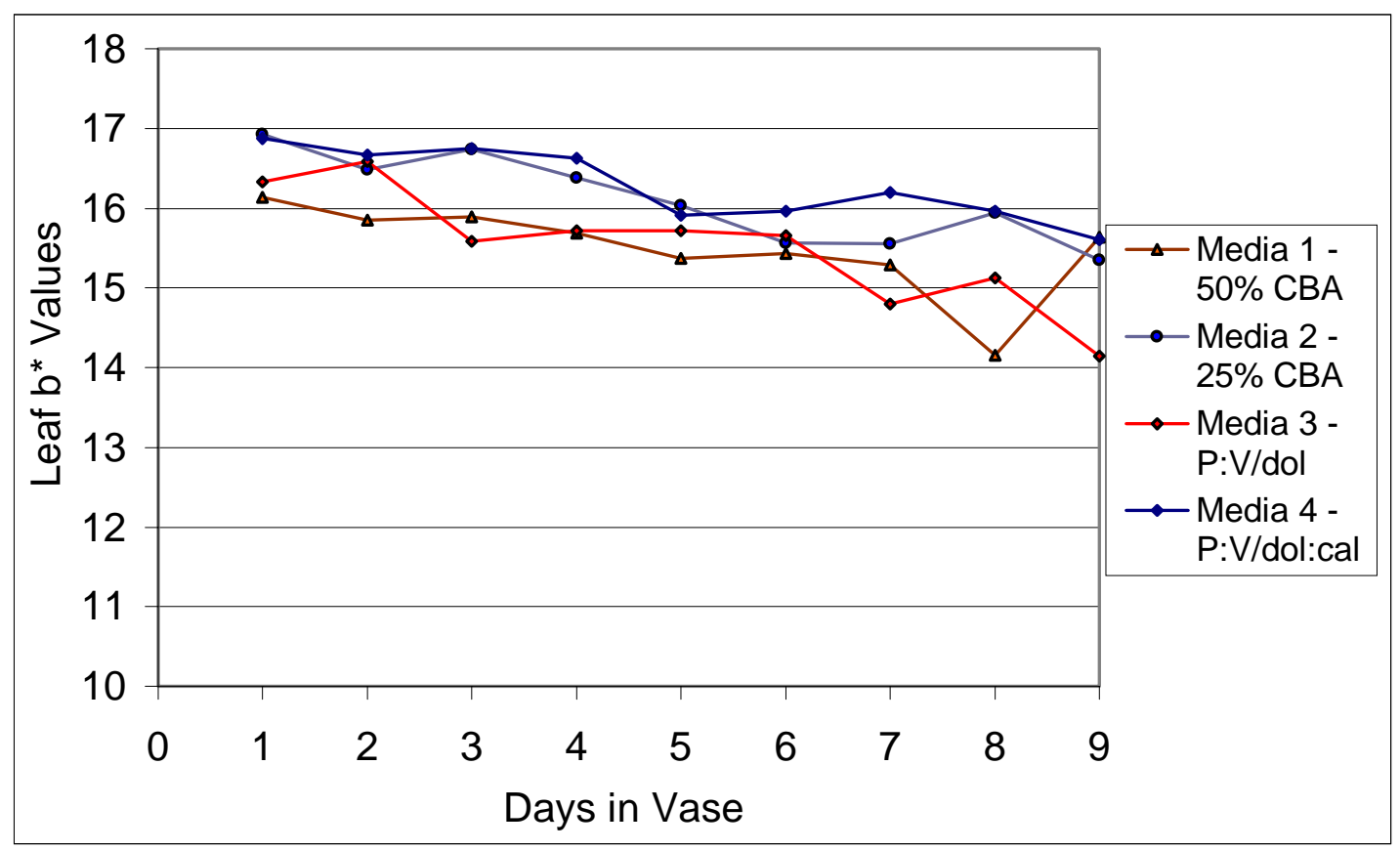

Figure 3.11 Leaf $b^{*}$ values for each of the four media used. (Data from both cultivars has been combined.) Significant evidence that media affects $b^{*}$. 


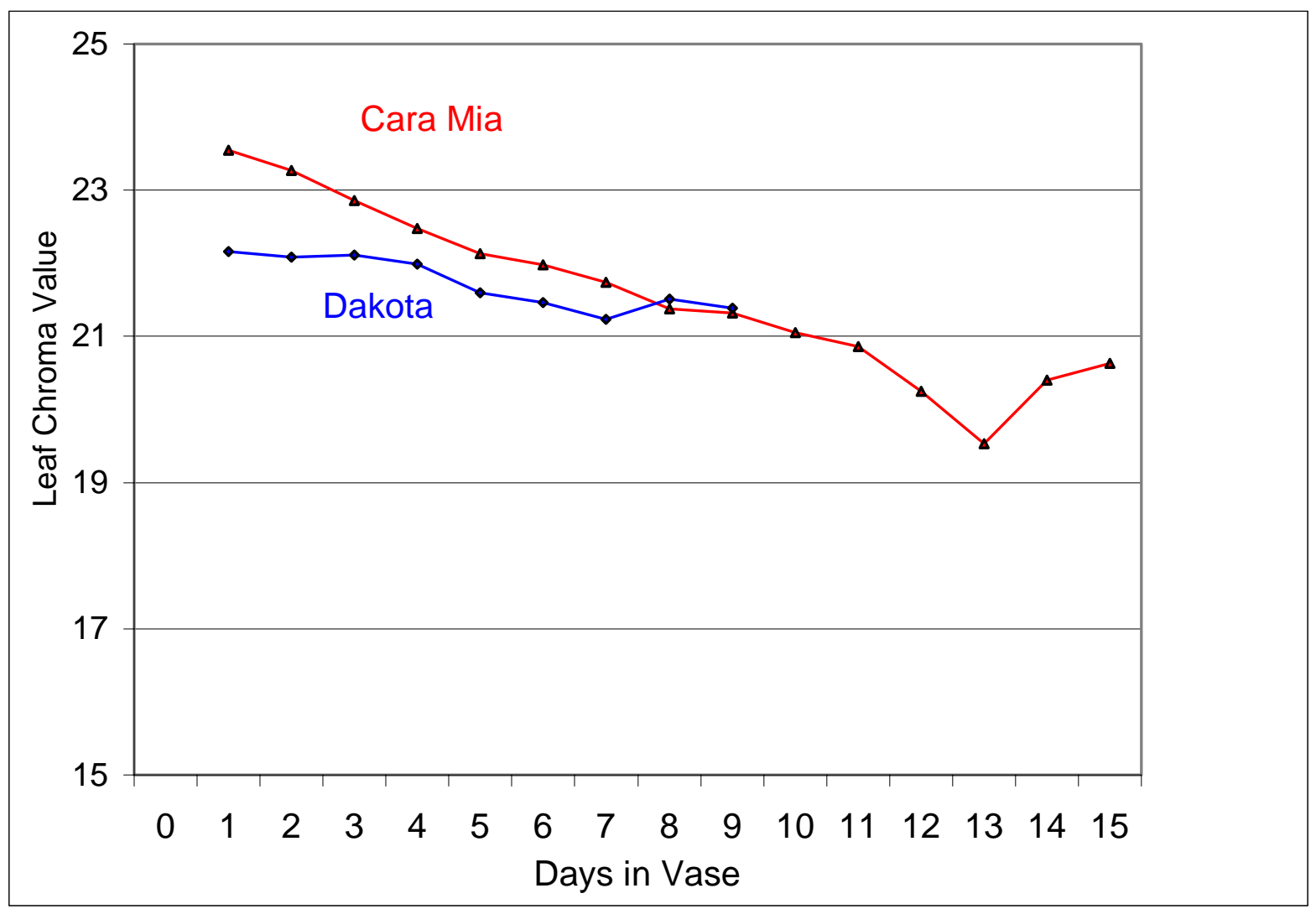

Figure 3.12 Leaf chroma for Cara Mia and Dakota roses as they senesce. There is significant evidence that chroma is decreasing for both cultivars as vase life progresses, and that this decrease is more rapid for Cara Mia. M. S. error $=.6082$. 


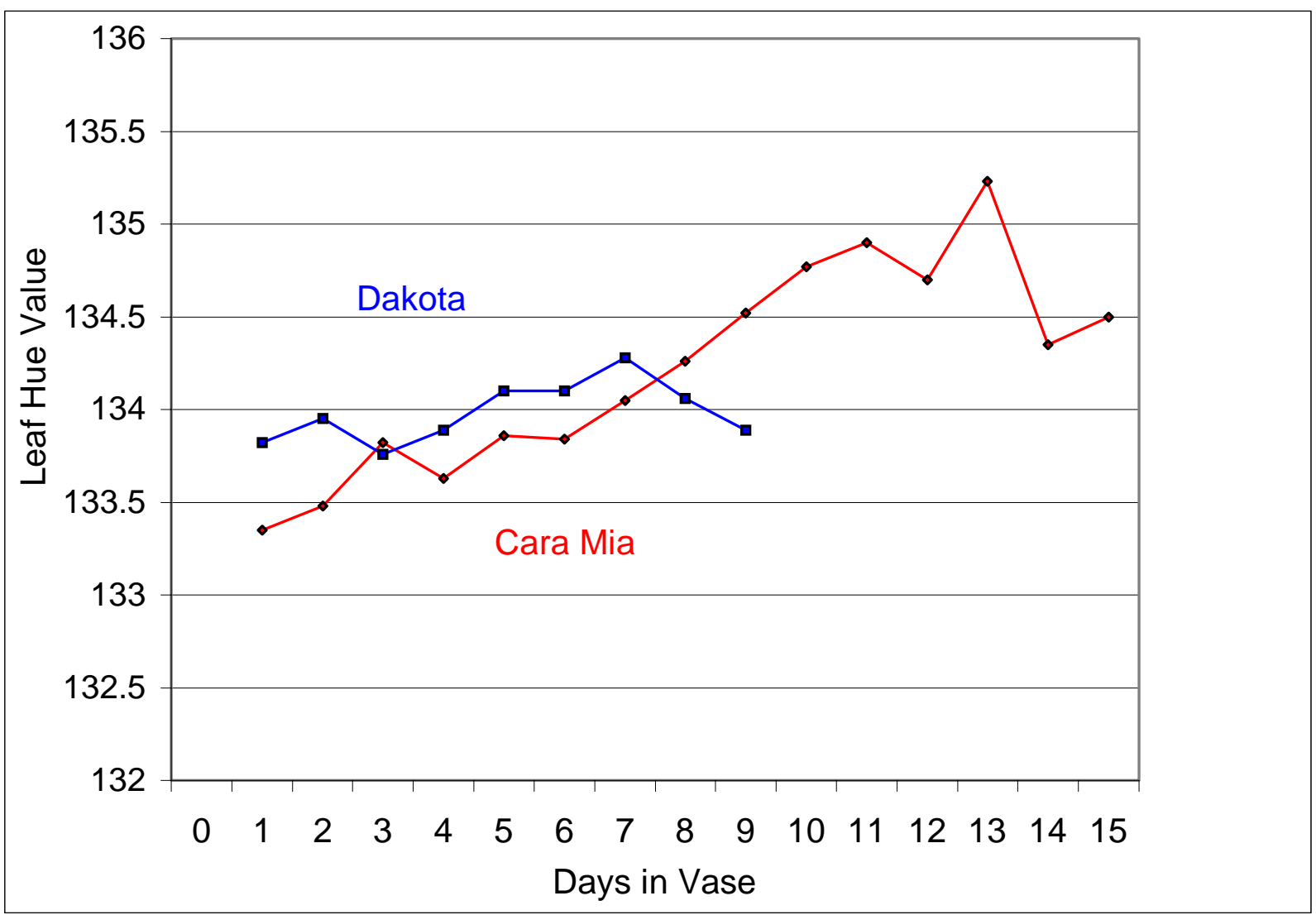

Figure 3.13 Leaf hue for Cara Mia and Dakota roses as they senesce. There is significant evidence that hue is increasing for both cultivars as vase life progresses, and that this increase is more rapid for Cara Mia. M. S. error $=.4848$. 


\begin{tabular}{|c|c|c|}
\hline Media & Cara Mia & Dakota \\
\hline \hline Media 1 - 50\% CBA & 75 & 69.6 \\
\hline Media 2 - 25\% CBA & 76.5 & 67.9 \\
\hline Media 3 - P:V/dol & 76.1 & 69.8 \\
\hline Media 4 - P:V/dol:cal & 78.1 & 71.7 \\
\hline \hline Average & 76.4 & 69.5 \\
\hline
\end{tabular}

Table 3.2 Subjective visual assesment of Cara Mia and Dakota roses by a panel of judges. No evidence of a difference due to media was found. A significant difference was found between the two cultivars.

\begin{tabular}{|c|c|c|}
\hline Media & Cara Mia & Dakota \\
\hline \hline Media 1 - 50\% CBA & 5.9 & 5.6 \\
\hline Media 2 - 25\% CBA & 6.8 & 5.5 \\
\hline Media 3 - P:V/dol & 5.9 & 5.7 \\
\hline Media 4 - P:V/dol:cal & 6.8 & 6.3 \\
\hline \hline Average & 6.2 & 5.5 \\
\hline
\end{tabular}

Table 3.3 Subjective assesment of scent by a panel of judges. No evidence of a difference due to media was found. Assesment of the scent was not significantly different depending on cultivar. 


\section{Discussion}

\section{Petal Color}

All four cultivars of roses in this study showed a distinct pattern of color change as they senesced. Interestingly, all four cultivars exhibited a decrease in the yellow quality $\left(b^{*}\right)$ as they senesced. The two red cultivars, in addition, showed a decrease in the red quality $\left(\mathrm{a}^{*}\right)$ after full expansion.

An important point is that our color measurements $\left(a^{*}\right.$ and $\left.b^{*}\right)$ may not directly reflect biochemical changes in the petals. For example, in the red roses, changes in anthocyanin pigments may be causing a shift in color from red to blue. This may explain the measured decrease in red $\left(a^{*}\right)$ and the decrease in yellow $\left(b^{*}\right)-$ which can also be looked at as an increase in blue. (The decrease in $b^{*}$ may also be explained as the breakdown of some other pigment that causes a yellow color.)

In any case, the typical pattern of color change for a cultivar could be used to monitor the stage of senescence that a rose is in. This could be useful during post harvest studies, since monitoring color is easy and nondestructive.

Cara Mia roses grown in 50\% CBA had a lower hue overall than the other roses. In visual terms, this meant that these roses were less red and slightly more toward the blue pole (Table 3.1). (This difference, which was statistically significant according to the chroma meter measurements, was not noticeable to the eye.) It is possible that CBA contains some metal in higher amounts that is causing this subtle difference in petal color. Also, hue for Pink Osiana roses grown in 50\% CBA was different than hue for the other roses. This cultivar often has a greenish yellow cast in its pink petals at cutting. This is reflected in the hue value, and as the flowers loose this greenish tint in the first few days in the vase, the hue values drop (color is shifting more toward the red (pink) and away from the yellow). In roses from 50\% CBA, the hue at cutting is already a lower value; roses are already more pink (Figure 3.6). As in Cara Mia, it is possible that some mineral difference in the media is causing this color difference.

It is not likely that either of these differences due to media are economically important. The change in Cara Mia is not noticeable, though it is probably undesirable 
since a red color without bluing is preferred. The change in Pink Osiana may be positive or negative, depending on customer preference.

\section{Leaf Color}

The $\mathrm{L}^{*} \mathrm{a} \mathrm{b}^{*}$ measurements of the cut rose leaves can be used to indicate what is happening to the chlorophyll in the leaves. It will not indicate the quantity of chlorophyll since a standard curve of a* or chroma vs. [chlorophyll] was not done for each cultivar. The measurements can, however, be used to indicate a general trend. Both the chroma and the $-\mathrm{a}^{*}$ values have been correlated to leaf chlorophyll (Singha and Townsend, 1989) (Steet and Tong, 1996).

From leaf chroma (Figure 3.12) and from leaf $-\mathrm{a}^{*}$ values (Figure 3.8) it can be inferred that chlorophyll is decreasing in the leaves during the vase lives of the roses. This is most likely due to chlorophyll breakdown. It has been shown that in senescing leaves, chlorophyll breakdown occurs due to a controlled, energy-requiring process. This process allows the apoproteins that are complexed with chlorophyll to be broken down and, therefore, nitrogen is salvaged by the plant (Matile et al., 1996). We can hypothesize that this is occurring in the rose leaves and that the salvaged nitrogen is used by the developing flower. (This is only a hypothesis, though, and further research would be needed to clarify this phenomenon.

Leaf $b^{*}$ values (yellow-green) also decrease in leaves, in much the same way as a* values do. It is possible that this decrease in yellow indicates the breakdown of another pigment as senescence progresses. (This occurred in petals, too.)

It is interesting to note that the longer-lived Cara Mia leaves, at cutting, has a significantly more negative $\mathrm{a}^{*}$ value (more green) than Dakota. We can hypothesize that this indicates more chlorophyll, but without making a standard curve of - $\mathrm{a}^{*}$ vs. [chlorophyll], we cannot know this. Other differences in pigments between these two cultivars may be affecting the $-\mathrm{a}^{*}$ readings. Also, in Cara Mia, $\mathrm{a}^{*}$ values increase at a faster rate indicating, perhaps, that chlorophyll is broken down faster in Cara Mia, thereby supplying the flowers with more nitrogen. This could be one of the genetic qualities that give Cara Mia its longer vase life. 


\section{Subjective Analysis}

No significant difference due to media was found when roses were rated by a panel of judges. Overall, the judges rated Cara Mia roses higher than Dakota. Cara Mia roses have a very classical vase shape when first cut. Dakota roses are not so elegant in the bud stage, but once they begin to open, the form is lovely. The cultivar preference of the judges probably reflects this timing issue, since the roses were all judged at the oneday stage. This is, however, a typical stage for judging roses (Pi Alpha Xi Judging Standards Committee, 1983). 


\section{Chapter 4 Ethylene production}

\section{Introduction}

Ethylene is a unique plant growth regulator in that it is a gas and can move through plant tissue (and even plant to plant) freely. Ethylene diffuses through air with a diffusion coefficient 10,000 times higher than that in water and ethylene is 14 times more soluble in lipid than in water (Ableles et al., 1992). Therefore, it moves easily through membranes. It is thought to play a major role in the process of petal senescence (Borochov and Woodson, 1989). Its ability to diffuse so easily may allow it to synchronize the process of senescence throughout certain tissues. Evidence has accumulated of membrane receptors for ethylene that are metalloproteins. Ethylene has been shown to cause de novo protein synthesis through transcriptional changes (Woodson and Lawton, 1988). Some of the genes believed to be affected by ethylene play direct roles in senescence. These include genes for polygalacturonase, cellulase (Mattoo and Aharoni, 1988), glucosidase and cellobiase (Jones et al., 1994). Ethylene has also been shown to be autocatalytic in that ethylene from another part of the plant or from an outside source can cause tissue to begin synthesizing its own ethylene (Woodson and Lawton, 1988). In carnation flowers, it has been shown that ethylene production begins in the ovary and that this ethylene diffuses outward and acts as a signal to petals to begin autocatalytic ethylene production (Have and Woltering, 1997).

There is some controversy about the importance of ethylene in roses. Reid et al. (1989) report that ethylene is unimportant in rose senescence unless present exogenously. Conversely, Mor and Zeislin (1987) and Halevy and Mayak (1981) showed endogenous production of ethylene by roses at the terminal stage of senescence. Several other reports of ethylene production in roses have indicated that the level is very low when compared to carnations or petunias, and this contributes to the measurement difficulty.

The reaction of roses to silver thiosulfate (STS) supports the importance of ethylene in rose senescence. STS sprayed on roses has been shown to improve their longevity (Cushman et al., 1994) (Staby, 1994). It is also recommended as a pulse treatment for roses at cutting or when they arrive at the retailer (Staby, 1994). STS is an ethylene action inhibitor. It is believed to work by reacting directly with ethylene's 
binding sites and thereby preventing ethylene binding and action (Reid et al., 1989). It can be proposed that if ethylene was not important in rose senescence, then STS would not affect rose longevity. Also, Müller et al. (2000) have isolated a putative ethylene receptor from miniature roses and found that the genes for two enzymes in the ethylene biosynthesis pathway are up-regulated during senescence of rose petals.

Simply stated, the biosynthesis of ethylene follows this pathway: methionine $\rightarrow$ $(\mathrm{SAM}) \rightarrow(\mathrm{ACC}) \rightarrow$ ethylene (Savin et al., 1995). The conversion of SAM to ACC is catalyzed by ACC synthase (ACS). This is the rate-limiting step (Oeller et al., 1991). Conversion of ACC to ethylene is catalyzed by ACC oxidase (ACO). Regulation of ethylene production can occur by changes in the activity or biosynthesis of these enzymes. In fact, the autocatalytic ethylene production mentioned above is thought to be triggered by exogenous ethylene inducing ACS and ACO genes (Savin et al., 1995). These are the two enzymes that Müller et al. (2000) found to be up-regulated during rose senescence. The simplest and most accurate method for measuring ethylene is usually considered to be gas chromatography with a flame ionization detector (Abeles et al., 1992).

Different rose cultivars, as well as different flower species, are affected by ethylene at different concentrations. One rose cultivar, 'Lovely Girl', tested by Reid et al. (1989) was affected by as little as $20 \mathrm{ppb}$ ethylene and the effect was saturated at 120 ppb. As a comparison, supermarket ambient air routinely tested at $20 \mathrm{ppb}$ ethylene. Cara Mia, in Reid's study, was only affected at higher ethylene amounts.

\section{Materials and Methods}

\section{Plant Material}

Rosa x hybrida cvs Dakota and Cara Mia were used for this study. These roses were the fourth crop taken from the bushes. Cutting was done from August 21 to September 16, 1999. All roses used in this study were cut in the morning and treated as described in the Materials and Methods section of Chapter 2. After conditioning 
overnight, each rose was recut and randomly assigned to a vase life length of $1,2,3 \ldots \ldots 12$ days. They were held for that time period on the light bench under the same conditions as described in Chapter 2.

\section{Ethylene measurement}

Ethylene production was measured for Dakota and Cara Mia roses over their vase lives. Each morning from September 2 until September 28, the group of roses to be tested that day was moved to the GC lab. At four-minute intervals, six outer petals were removed from a rose and were used as one sample. (Four-minute intervals were used since it required approximately three minutes to run a sample through the gas chromatograph.) An attempt was made to obtain six measurements for each cultivar/media combination for each time period. Since measurements were to be obtained for each day of the vase life, this became a very large number of roses. Also, the roses had to be scheduled so that no more than 30 flowers were ready on any given day. (Thirty was the largest number that could be run each day practically.) For these reasons, this study was not perfectly balanced with each treatment having exactly six measurements. Instead, some treatments, if possible near the expected ethylene peak, had more measurements and some had less. For day 1,2 and 3 - the time when the roses were still expanding (senescence had not begun) - only one measurement was made for each treatment. Because the desired number of samples was so large, each rose was used twice.

Ethylene in headspace samples was measured using the method of Verlinden (personal communication) and the protocols described by Abeles et al. (1992) and Saltveit (1982 and 1984). Each sample of petals was placed in a $40 \mathrm{ml}$ glass sample vial with a septum lid. Each vial contained $15 \mathrm{ml}$ distilled water and the lower tips of the petals were placed just below the surface. (The outermost 2 petals of each rose were discarded.) The sealed vials were held for 2 hours at room temperature. Then, headspace samples of one $\mathrm{ml}$ were withdrawn by syringe from each vial and the entire sample was injected into a Hewlett Packard 5890 Series II gas chromatograph equipped with a flame 
ionization detector and a 45/60 Carboxen 1000 column. For each run, a blank and an ethylene sample were included.

For each ethylene peak, height and base measurements were taken and the area under the peak was calculated as height $\mathrm{X}$ base $\mathrm{X} 0.5$. Area measurements are considered more accurate than peak heights for quantifying ethylene (Saltveit, 1982). Ethylene concentrations were calculated from area measurements by comparison to a standard of known concentration. The standard used was a newly purchased $10 \mathrm{ppm}$ ethylene standard.

\section{Statistical Analysis}

Data on ethylene production was analyzed using the GLM procedure in SAS as a split-split plot over time. Cultivar was used as the main plot treatment arranged in blocks. Media was a subplot treatment arranged in a Latin square and day was a sub-sub plot treatment. The statistical model used for this analysis is shown in Appendix Figure A.4.3.

\section{Results}

During the first three days of the vase life, while the roses were still expanding, exceedingly low levels of ethylene were detected. Figure 4.1 shows ethylene production for the two cultivars. For each point shown, data from all four media were averaged, since no media effect was found. This means that each point represents the average of 16-30 measurements. Cara Mia produced more ethylene than Dakota. There was significant evidence that the two cultivars followed a different pattern of ethylene evolution. Dakota reached its highest rate of production $\left(0.6 \mathrm{nl} \cdot \mathrm{g}^{-1} \cdot \mathrm{h}^{-1}\right)$ at 6-7 days. For Cara Mia, the highest rate of ethylene production $\left(1.6 \mathrm{nl} \cdot \mathrm{g}^{-1} \cdot \mathrm{h}^{-1}\right)$ occurred at 9 days. After the peak, ethylene production dropped off for both cultivars, but was still measurable.

No sufficient evidence of a difference due to media was found for ethylene production. A great deal of variability was found from flower to flower, and given the variability of this factor, many more samples would be required for small differences due 
to media to be detected. A graph of ethylene production showing a separate curve for each media/cultivar combination can be found in Appendix Figure A-4-1. (Also, see Appendix Figure A-4-2, which shows a scatter plot of this data.

According to Yip and Yang (1993), the detection limit for a system like the one used here should be, at best, about $0.01 \mathrm{nl} / \mathrm{ml}$. The petals in this study, at the beginning of the vase life, produced ethylene at the rate of about $0.2 \mathrm{nl} \cdot \mathrm{g}^{-1} \cdot \mathrm{h}^{-1}$. Taking into account the weight of petal tissue, the vial volume, and the time in the vial, this means that the head space sample injected into the G.C. from these petals had a concentration of about 0.06 $\mathrm{nl} \cdot \mathrm{g}^{-1} \cdot \mathrm{h}^{-1}$. This is above the $0.01 \mathrm{nl} / \mathrm{ml}$ detection limit. 


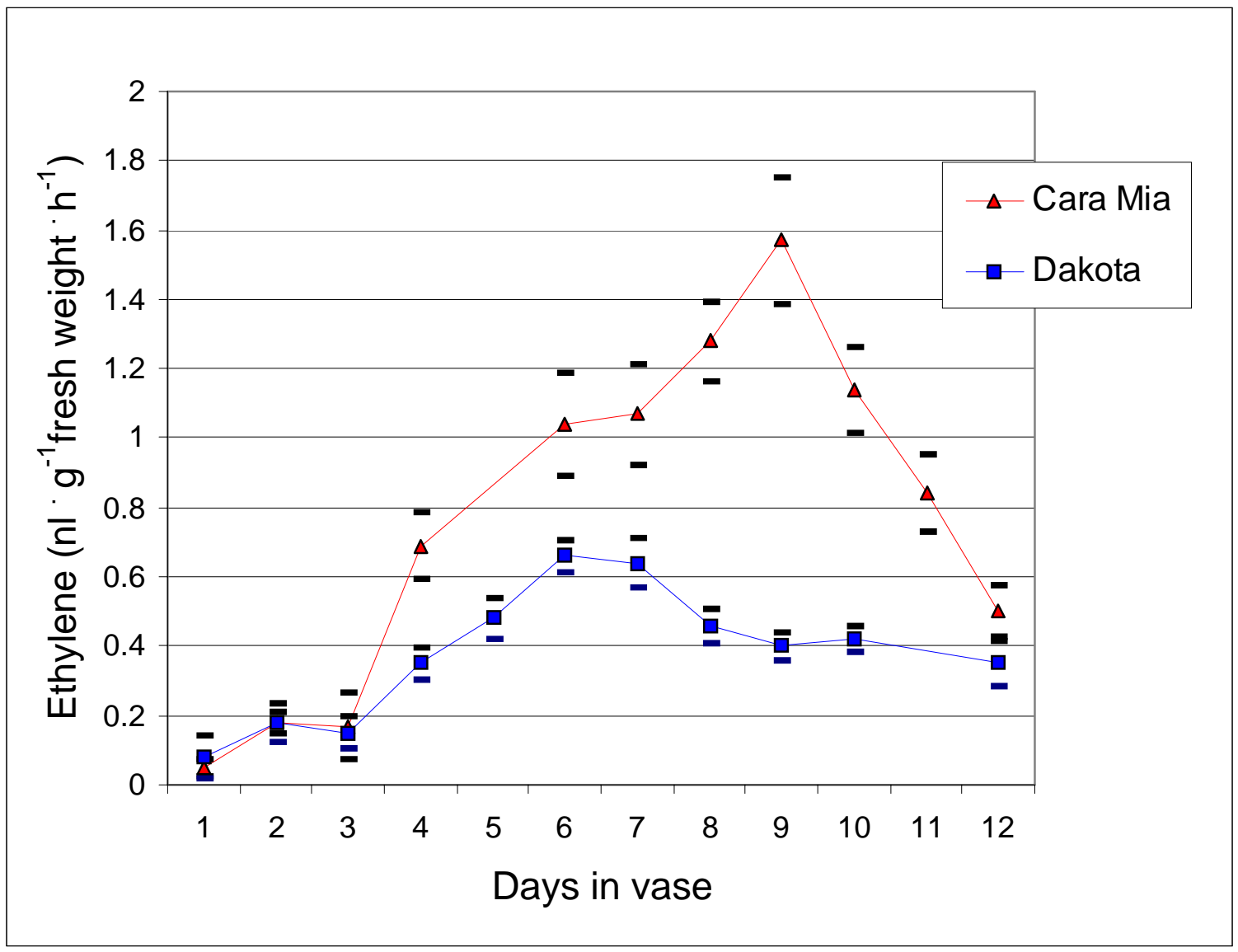

Figure 4.1. Ethylene production by fresh rose petals over the vase life. Error bars represent $+/$ - one s.e. Each point is the mean of 16-30 measurements except the day 1,2 , and 3 measurements, which are an average of 4 measurements (one from each media). No evidence of a difference due to media was found. The two cultivars are significantly different in their ethylene production at the $\mathrm{p}=0.05$ level, and the pattern of change is different for the two cultivars. 


\section{Discussion}

Ethylene production proved difficult to monitor for two main reasons: first, the amounts involved in roses were very low - near the limits of detection for the GC; and second, no acceptable method for repeat measurements from one flower was found. This meant that different flowers made up each point on the graph and very large quantities of roses were required.

While ethylene production for these rose cultivars was low, it was a measurable amount, and a difference was found between the two cultivars. This difference was twofold. First, ethylene production can be seen to peak earlier in Dakota than in Cara Mia roses. This parallels the difference in vase life between the cultivars and may reflect a difference in the timing of the processes of senescence.

The second cultivar difference apparent in these results is the amount of ethylene produced. Cara Mia, even though it has a longer vase life, produced more ethylene than did Dakota. Both amounts, however, are significantly lower than the amount of ethylene produced by senescing carnations (up to $45 \mathrm{nl} / \mathrm{g} \mathrm{h}$ ) (Savin et al., 1995) or petunias (up to $15 \mathrm{nl} / \mathrm{g} \mathrm{h}$ ). It is thought that the amount of ethylene required to produce a full physiological response in tissue differs according to the genetics of the plant involved and its developmental stage. It has been proposed that this may have to do with the number and affinity of the ethylene receptors in that tissue and to regulation at other points in the ethylene response pathway. Müller et al. (2000) found differences in the level of a putative ethylene receptor in two miniature rose varieties and correlated the these differences with longevity. Roses, in general, may require much lower concentrations before responding than carnations (i.e. they may be much more sensitive). And Dakota may be even more sensitive than Cara Mia. The ethylene production found for Dakota in this study is very similar to that found for cv. Golden Wave by Mayak and Halevy (1972).

It should be noted that petals alone were sampled. If other flower parts were producing ethylene (likely candidates include the ovary or pollen), this ethylene was not included in the measurements. Typically, other parts of the flower are the original source of ethylene. This ethylene, then, travels throughout the flower and may trigger the petals to begin to produce their own ethylene. This scenario has been proposed for carnations (Savin et al., 1995). The data presented in Figure 4.1, therefore, supports the idea that rose petals 
produce their own ethylene, and that the timing of this endogenous ethylene production seems to coincide with the onset of senescence and the end of vase life.

Two other possible "sources" of ethylene must be considered as possibly confounding the data. "Wound or stress ethylene" is produced in response to any mechanical damage that the researcher may do to the tissue. It can clearly contribute to measured ethylene if the petals are cut into discs or strips (Abeles et al., 1992). In this study, however, petals were gently removed without tearing. Some "wounding" was possible at the point of detachment, but since this treatment was the same for every petal, and many of the day 1 , 2 and 3 petals gave zero readings for ethylene, wound ethylene was not considered a confounding problem.

Ethylene can also be produced, as a breakdown product of membranes. At the end of vase life, as cells are dying and tissue is beginning to physically deteriorate, membrane lipids can begin to be oxidized and some ethylene may be formed. This reaction only occurs at the very end of the senescence process. The ethylene measured in this study was not likely to include this source of ethylene, except perhaps very late in the experiment. 


\section{Chapter 5 - Calcium in Rose Tissues and Cell Walls}

\section{Introduction}

Evidence has accumulated that the level of calcium in the plant tissue can affect the process of senescence. Too little calcium can cause tip burn in lettuce, blossom end rot in tomato, and bitter pit in apples (Marschner, 1995). $\mathrm{CaCl}_{2}$ sprays are used on apples to improve firmness during storage and have been shown to increase the pectin content (Siddiqui and Bangerth, 1995). Calcium sprays have also improved postharvest quality of cut gerberas (Gerasopoulos and Chebli, 1999). Potted miniature roses grown in a nutrient solution with increased calcium exhibited better postharvest performance (Starkey and Pederson, 1997). Torre, et al. (1999) found that adding $\mathrm{CaCl}_{2}$ to the vase water of cut roses (or individual petals) lengthened the vase life, and attributed this to a possible increased calcium level in the petals. Loss of turgor, which occurs as roses senesce, was also delayed by this calcium treatment.

Most often it is the low-transpiration organs of the plant that display disorders due to calcium deficiency. Cut roses, as well as fruits and tubers, fit into this category. It is thought that calcium arrives at these tissues almost entirely via the xylem (Marschner, 1995), and therefore low transpiration would result in less calcium transport to these organs. This phenomenon has been proposed to explain why roses grown at high relative humidity have lower calcium levels and shorter vase lives (Torre, et al., 1999).

A question raised in this research is whether increased calcium in the media will cause an increase in petal tissue calcium and thereby increase the vase life. Starkey and Pedersen (1997) grew miniature roses with nutrient solutions of varying Ca content. They found that as calcium increased in the nutrient solution, so did the percentage of calcium in the whole roses and buds. However, these measurements included all flower parts and not just the petals. On the other hand, Quintana et al., (1999) has shown that in bean

pods (another low-transpiration organ), increased fertilization did not affect the amount of calcium in the pods. The only parameter that significantly affected calcium concentration was cultivar, indicating a strong genetic component to calcium accumulation.

Different plant species or varieties may differ in their requirements for calcium. Genotypic differences in the number of binding sites in the cell wall are thought to 
determine these requirements (Marschner, 1995). These binding sites have been considered the cation exchange capacity of the cell wall (Marschner, 1995) (Demarty, et al., 1984).

From the forgoing discussion, it can be summarized that the amount of calcium in the flower tissue may depend on both the calcium availability to the roots and the genetic characteristics of the plant that determine Ca uptake and cation exchange requirements of the cell walls.

In addition to what is known about the limited transport of calcium into lowtranspiration organs, it is also known that the great majority of calcium that reaches these tissues remains in the cell wall (Siddiqui and Bangerth, 1995) (Demarty et al., 1984). In other tissues such as leaves, calcium is also stored in the vacuoles and possibly in other organelles. There, it is stored as chelates or as precipitates of organic acids. But it is in the apoplastic space that calcium is thought to play a critical role in delaying senescence. Here, it interacts with both cell membranes and cell walls to stabilize them. Calcium's effects on cell membranes will be discussed in Chapter 6.

In the cell wall, calcium is thought to cross-link the pectic polysaccharides, thereby stabilizing the wall (Kobayashi et al., 1999). The structure of cell walls, and specifically the pectin network, has been the subject of recent reviews (Hadfield and Bennett, 1998) (Carpita et al., 1996) (Fry, 1989) (Jarvis, 1984). The dynamic nature of the wall is becoming better understood. Changes in the pectic network are an integral part of the plant's development, including growth and expansion, abscission, ripening, pollen maturation and xylem formation (Hadfield and Bennett, 1998). And changes to the petal cell walls as the flowers senesce can be expected.

In this study, the quantity of cell wall material and the cell wall calcium was studied. It was hoped that this would add to our understanding of the process of senescence in rose flowers, and the role of calcium in delaying it. 


\section{Materials and methods}

\section{Plant material}

Rosa x hybrida cvs Dakota, Cara Mia, Santa Fe, and Pink Osiana were used for this study. These roses were the third crop taken from the bushes. Cutting was done from May 12 to June 1, 1999. Leaf tissue analysis reported in this chapter includes the data from Crop 2 and Crop 3 roses. Petal tissue analysis at the time of cutting was conducted on both crops, as well, but in this case, results are reported separately.

All roses were cut in the morning, at the stage when sepals were reflexed and two petals had loosened from the tight bud. They were handled in the same way as described for Crop 1 (See Materials and Methods, Chapter 2).

\section{Leaf and petal tissue analysis}

Leaf tissue samples were taken as a composite sample of 25 leaves gathered at the time of flower harvest. They included only the uppermost two 5-leaflet leaves from the flowering stems. Petal tissue samples were composed of all of the petals from one flower and included no other flower parts. Petal tissue was sampled at 0, 4, 8, and 14 days in the vase. Three flowers were sampled for each media:cultivar combination and for each postharvest period.

For nutrient analysis, leaf or petal tissue was dried in a drying oven for $48 \mathrm{~h}$ at $65^{\circ} \mathrm{C}$. Tissue was then ground with a mortar and pestle to pass through a 35 mesh screen. A $0.2 \mathrm{~g}$ sample was dry ashed for $4 \mathrm{~h}$ at $500^{\circ} \mathrm{C}$. Ten $\mathrm{ml}$ of $\mathrm{HCl} / \mathrm{HNO}_{3}$ acid solution $(100 \mathrm{ml}$ $\mathrm{HNO}_{3}$ and $300 \mathrm{ml} \mathrm{HCl}$ in one liter) were added to each sample with gentle heat to dissolve the ash. Samples were brought to $50 \mathrm{ml}$ and filtered through Whatman 42 paper, then $\mathrm{LaCl}_{2}$ was added to each. Calcium and magnesium were determined on an atomic absorption spectrophotometer. $\mathrm{Mn}, \mathrm{B}, \mathrm{Al}, \mathrm{K}, \mathrm{Fe}, \mathrm{Cu}, \mathrm{Na}$, and $\mathrm{Zn}$ were analyzed with an ICP atomic emission spectrophotometer. 


\section{Cell wall extraction}

Cell walls were isolated from frozen petal tissue using a modification of the methods of Alonzo et al. (1997) and Jiménez et al. (1997). Four petals from each flower were used. These were from the second whirl of petals - the outer two petals from each flower were always removed and discarded. The petals were weighed and then placed in a tube with $10 \mathrm{ml}$ of $95 \%$ ethanol. The remainder of the petals from each flower was used to determine fresh and dry weights. Each tube was homogenized with a glass hand homogenizer to break all of the cells. At this point, during test runs, microscopic assessments were done to determine whether all the tissue was homogenized. No intact cells could be seen using this method. Then each tube was incubated at room temperature for one hour. The homogenate was vacuum-filtered through pre-weighed Whatman 541 filter paper, was washed four times with $70 \%$ ethanol and three times with acetone. Filters were dried for two days in a drying oven at $65^{\circ} \mathrm{C}$. After weighing the filter paper plus residue so that total "cell wall" could be calculated, a sample of the residue was weighed into a crucible for dry-ashing. This residue was termed the AIR (alcohol insoluble residue). Dry-ashing was done as described for petal tissue analysis above.

\section{Statistical Analysis}

Data for leaf and petal tissue $\mathrm{Ca}$ and $\mathrm{Mg}$ from all four cultivars at the time of cutting were analyzed using a 2-way ANOVA in EXCEL. When a significant media or cultivar effect was found, mean separation was done using Duncan's New Multiple Range Test. Each number is the mean of four measurements for leaf analysis and of three measurements for petal analysis. For the other nutrients listed in Table 5.1, each number is the mean of two measurements.

The statistical analysis of $\mathrm{Ca}$ and $\mathrm{Mg}$ in the petal tissue over the vase life, and the cell wall analysis were done using the GLM procedure in SAS as a factorial arrangement of treatments in a completely randomized design. 


\section{Results}

\section{Leaf, and petal analysis}

Leaves from four cultivars; Cara Mia, Dakota, Pink Osiana, and Santa Fe; were analyzed for nutrients. The analysis (Table 5.1.and Figure 5.2.) showed that calcium was highest in roses grown in the 50\% CBA media, followed by P:V/dolomitic:calcitic and $25 \%$ CBA. In both cultivars, media 3 (P:V/dolomitic) had the lowest \% $\mathrm{Ca}$ in the leaf tissue. Figure 5.2 also shows results from a leaf tissue analysis of Pink Osiana and Santa $\mathrm{Fe}$, which have the same pattern of calcium accumulation. A bar graph of the vase life (Figure 5.1) is shown for comparison. The effect of media on vase life and leaf tissue $\mathrm{Ca}$ appears to follow the same pattern within each cultivar. The exception to this is that, for all four cultivars, roses from media 4 (P:V/dol:cal) had the longest vase lives, while their leaf $\mathrm{Ca}$ was comparable to that found for media 2 (25\% CBA).

Leaf tissue calcium was significantly lower in Cara Mia and Pink Osiana roses than in Dakota and Santa Fe overall, indicating a cultivar difference. Magnesium was not significantly different in leaf tissue due to media; nor was it significantly different in the two cultivars.

Significant media effects were found for leaf tissue levels of K, Mn, and Zn. These results are shown in Table 5.1.b. The two CBA-based media accumulated more K and $\mathrm{Mn}$ than the two media without CBA. Zn levels were significantly lower in leaf tissue from P:V/dol:cal (Media 4) than in the leaves of plants from the other three media.

Petal tissue was analyzed for $\mathrm{Ca}$ and $\mathrm{Mg}$ at the time of cutting for all four cultivars of roses. While leaf $\mathrm{Ca}$ appeared to be related to media $\mathrm{Ca}$ (see Table 2.3), and also related to vase life, this was not so for petal $\mathrm{Ca}$. In all cases, the $\mathrm{Ca}$ in petal tissue, per g of dry weight (Table 5.2.a.), was much lower than that found in the leaf tissue by a factor of about 12, and no differences were found due to growing media. As in the leaves, $\mathrm{Ca}$ in petal tissue was lower in Cara Mia and Pink Osiana roses than in Dakota and Santa Fe roses. In fact, in the two shorter vase life cultivars, Dakota and Santa $\mathrm{Fe}, \mathrm{Ca}$ was significantly higher (in both leaves and petals) than in the two longer vase life cultivars, Cara Mia and Pink Osiana. Levels of magnesium in the petal tissue were only 
slightly lower than leaf $\mathrm{Mg}$, approximately $2 / 3$ of that found in the leaves. No difference was found due to media, but one cultivar, Santa Fe, accumulated more magnesium in its petals than the other three cultivars (Table 5.2.b.).

For Cara Mia and Dakota, petal tissue calcium and magnesium were monitored over the vase life. Both $\mathrm{Mg}$ and $\mathrm{Ca}$ increased in the petal tissue over the vase life of the roses. This increase occurred even though the roses were held during this time in distilled water. This data is presented here in two forms. The first (Figure 5.3) is based on dry weight and allows a comparison between the two cultivars by eliminating differences due to petal size. The dry weight, however, changes over the vase life (most likely due to an increase in carbohydrate via the phloem followed by a decrease in carbohydrate due to respiration). Therefore, the data is also presented on a "per flower" basis that includes just the petals from one flower (Figure 5.4). This gives a clearer picture of what is entering and/ or leaving the petals during the vase life. (The drawback of looking at the data this way is that Dakota flowers are larger than Cara Mia flowers, so comparing the two cultivars is not of much interest.) No media effect was found for petal $\mathrm{Ca}$, so these two graphs represent the average for each cultivar over all four media. A small but significant media effect was found for magnesium, however. Flowers from media 1 $50 \% \mathrm{CBA}$ - had lower levels of $\mathrm{Mg}$ in their petal overall than flowers grown in the other three media (Figure 5.5)

\section{Cell Walls}

The dry weight of the alcohol insoluble residue (AIR) was determined and this was considered a measure of the cell wall fraction of the petal tissue. Figures 5.6 shows this quantity on a \% dry weight basis. Dakota had more cell wall material per g dry weight of petal tissue than Cara Mia. This was a small but significant difference. Figure 5.7 shows how the amount of cell wall in the petals changes over the vase life. No significant differences were found in the cell wall amounts due to media. Graphs of the amount of cell wall material for each media can be found in Appendix Figures A.5.1, A.5.2, and A.5.3. 
Calcium was analyzed in the AIR. On the basis of cell wall dry weight, calcium increased in the cell wall fraction over the vase life (Figure 5.8). No significant difference was found due to media. When the amount of calcium was expressed on a $\mathrm{mg} / \mathrm{g}$ of petal tissue basis (Figure 5.9) or on a per flower basis (Figure 5.10), the same trend was evident and ANOVA showed that calcium was increasing over the vase life in the same way for both cultivars. Again, no media effect was found.

The graph in Figure 5.11 shows total petal calcium and total cell wall calcium. The cell wall calcium here is shown as a $\%$ of the total petal dry weight. It is not possible that the cell wall calcium could actually be greater than the total calcium as the graph seems to indicate (significantly greater in for Dakota). This will be discussed in the next section. 


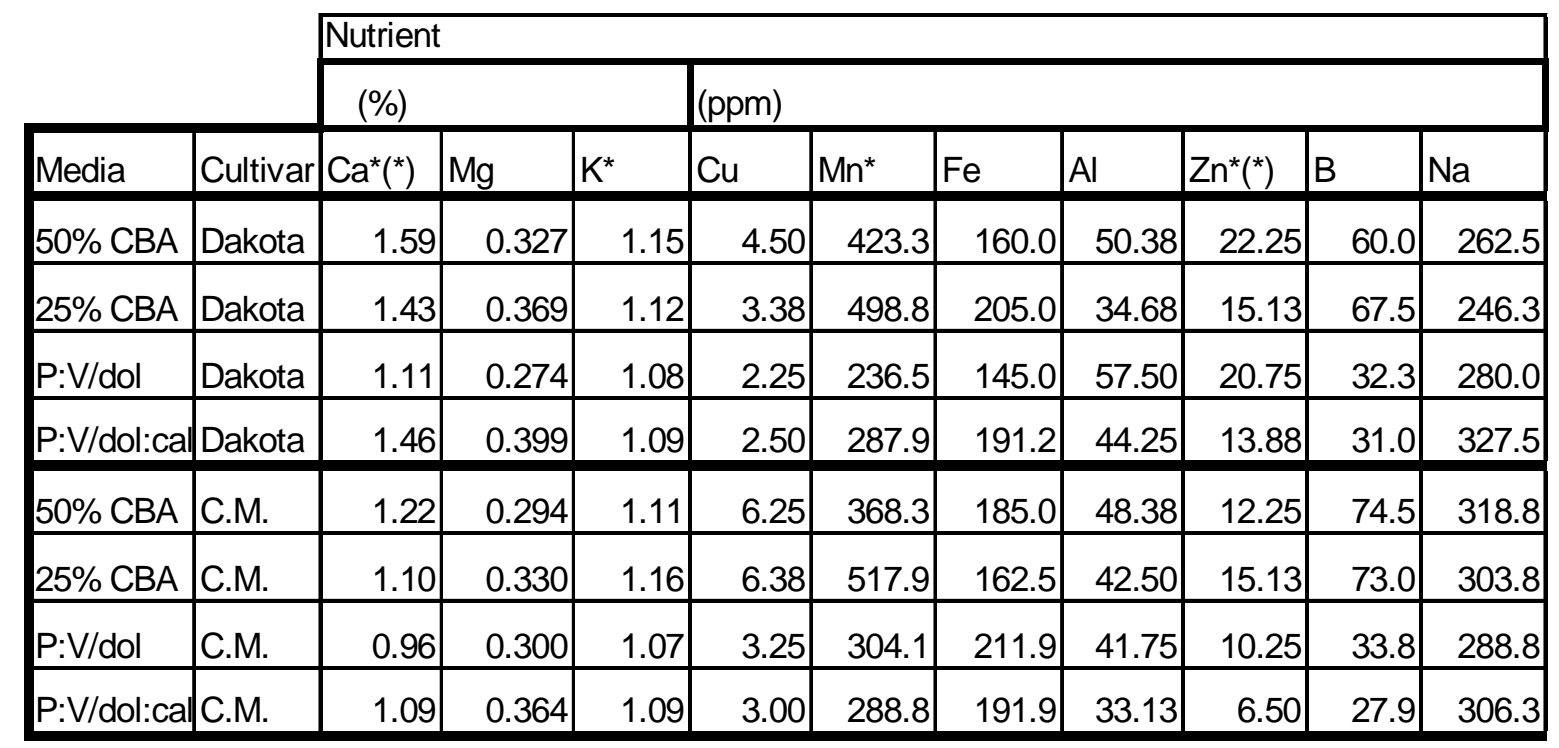

Table 5.1.a. Leaf tissue nutrient status of two rose cultivars grown in four media. Each number is the mean of 4 measurements for $\mathrm{Ca}$ and $\mathrm{Mg}$ and of 2 measurements for the other nutrients. Each measurement was a composite of 25 leaves from 6 different plants. *means different due to media. $\quad\left({ }^{*}\right)$ means different due to cultivar. Seperation of means for these nutrients (done with Duncan's NMRT)

\begin{tabular}{|c|cccc|}
\hline Media & $\mathrm{Ca}$ & $\mathrm{K}$ & $\mathrm{Mn}$ & $\mathrm{Zn}$ \\
\hline $50 \% \mathrm{CBA}$ & $1.45 \mathrm{a}$ & $1.13 \mathrm{a}$ & $395.8 \mathrm{~b}$ & $17.25 \mathrm{a}$ \\
\cline { 1 - 1 } $25 \% \mathrm{CBA}$ & $1.31 \mathrm{~b}$ & $1.14 \mathrm{a}$ & $508.3 \mathrm{a}$ & $15.13 \mathrm{a}$ \\
\cline { 1 - 2 } $\mathrm{P}: \mathrm{V} / \mathrm{dol}$ & $1.16 \mathrm{c}$ & $1.09 \mathrm{~b}$ & $270.3 \mathrm{c}$ & $15.50 \mathrm{a}$ \\
\cline { 1 - 4 } $\mathrm{P}: \mathrm{V} / \mathrm{dol}: \mathrm{cal}$ & $1.32 \mathrm{~b}$ & $1.08 \mathrm{~b}$ & $288.3 \mathrm{c}$ & $10.19 \mathrm{~b}$ \\
\hline
\end{tabular}

Table 5.1.b. Leaf tissue nutrient status, calculated as the mean of both cultivars. Different letters beside the means indicate significant differences at the $p=0.05$ level. 


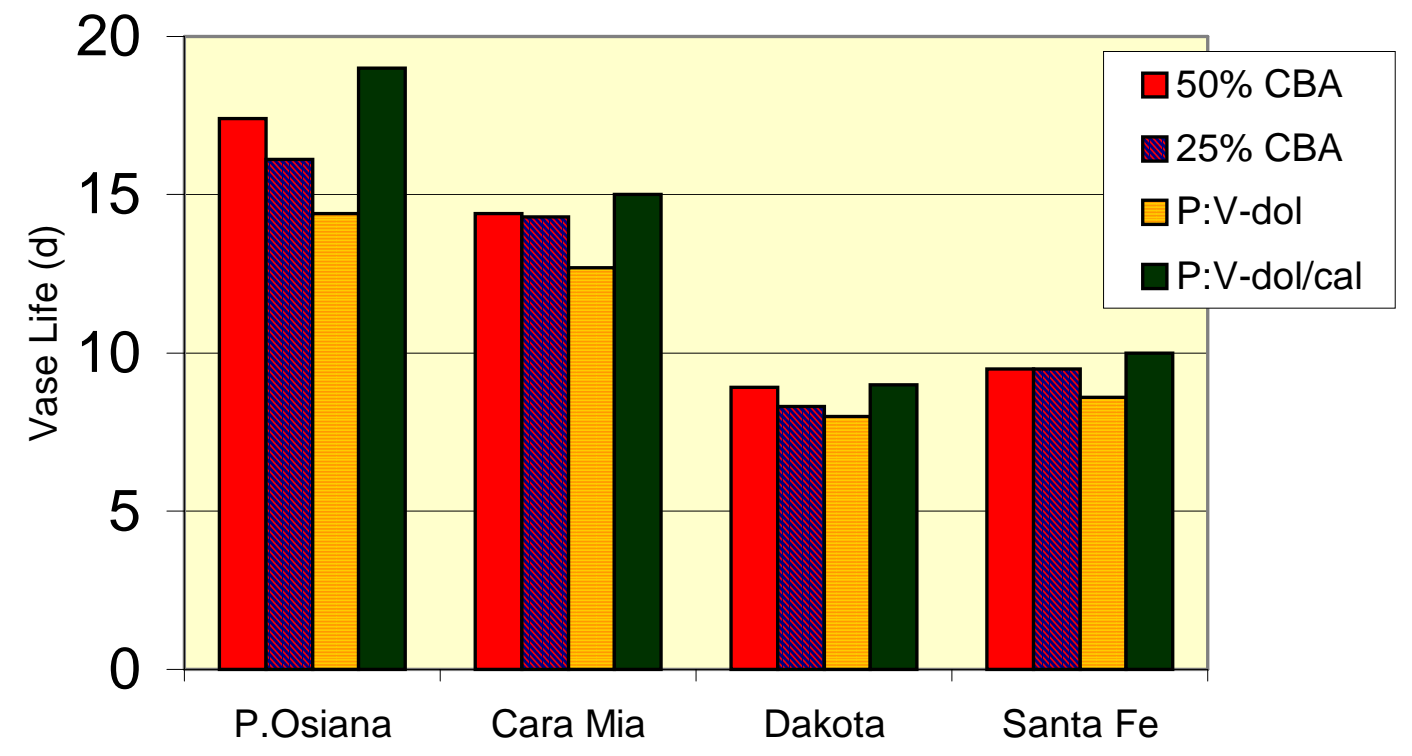

Figure 5.1 repeated from Chapter 2 for comparison. Vase life of four cultivars of roses grown in four media. The mean vase life (days) for each media (calculated as the mean of all four cultivars) was: P:V-dol/cal - 13.4 a.; 50\% CBA - 12.6 ab.; 25\% CBA - 12.1 b.; and P:V-dol - 10.9 c. Different letters beside the means indicate statistically significant differences at the $\mathrm{p}=0.05$ level.

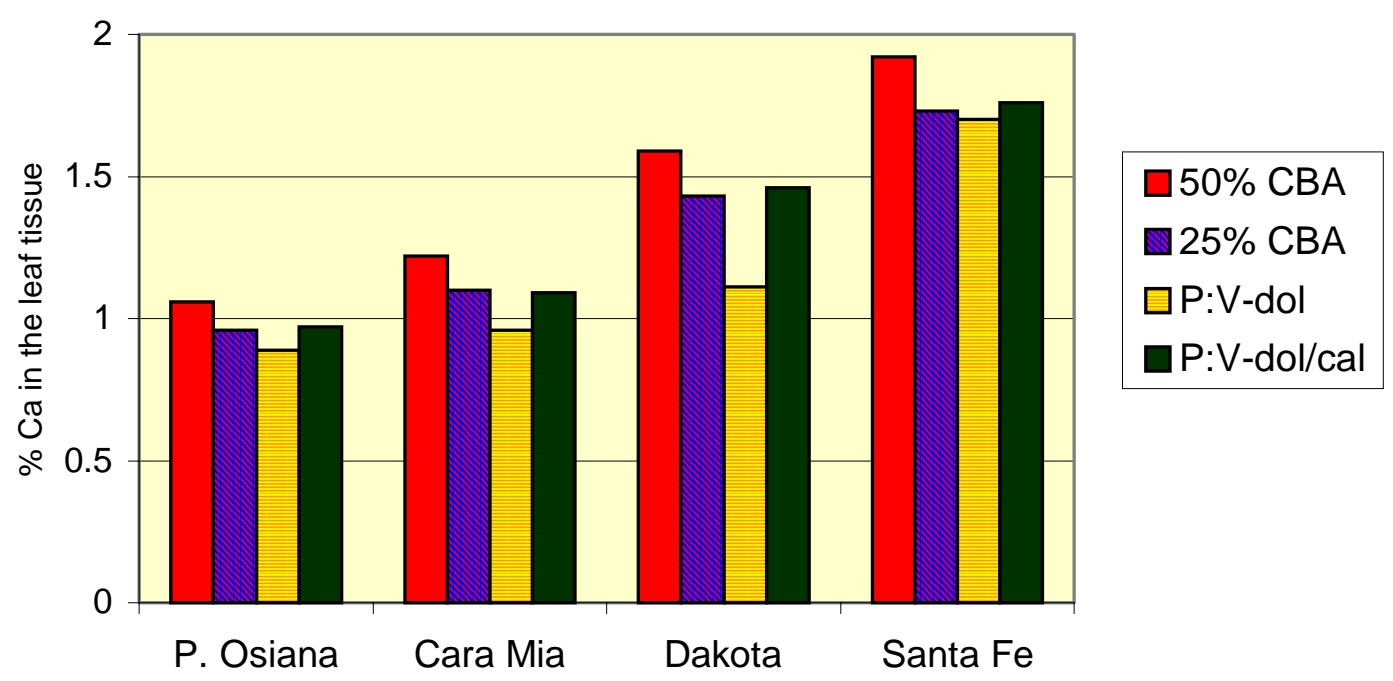

Figure 5.2. Calcium in the leaf tissue of Dakota, Cara Mia, Pink Osiana, and Santa Fe roses grown in four media. A significant difference was found due to media, and also due to cultivar. Mean seperation for the difference due to media is shown in Table 5.1.b. Mean Ca levels for each cultivar (calculated as the mean from all four media) were: Santa Fe-1.78-a; Dakota-1.40-b; Cara mia-1.10-c.; and Pink Osiana$.97-\mathrm{c}$. 


\begin{tabular}{|c|c|c|c|c|}
\hline Media & Cara Mia & Dakota & Santa Fe & P. Osiana \\
\hline $50 \%$ CBA & 0.09 & 0.113 & 0.117 & 0.083 \\
\hline $25 \%$ CBA & 0.089 & 0.103 & 0.111 & 0.101 \\
\hline P:V, dol. & 0.089 & 0.106 & 0.116 & 0.081 \\
\hline P:V, dol./calc. & 0.087 & 0.107 & 0.109 & 0.078 \\
\hline Cultivar Mean & $0.089 \mathrm{c}$ & $0.107 \mathrm{~b}$ & $0.113 \mathrm{a}$ & $0.086 \mathrm{c}$ \\
\hline
\end{tabular}

Table 5.2.a. Calcium in rose petals at the time of cutting as a $\%$ of the dry weight. No significant evidence of a media effect was found, but there was significant evidence of a cultivar effect. Different letters beside the cultivar means indicate a significant difference at the $p=0.05$ level.

\begin{tabular}{|c|c|c|c|c|}
\hline Media & Cara Mia & Dakota & Santa Fe & P. Osiana \\
\hline $50 \%$ CBA & 0.200 & 0.185 & 0.217 & 0.178 \\
\hline $25 \%$ CBA & 0.192 & 0.196 & 0.233 & 0.200 \\
\hline P:V, dol. & 0.193 & 0.195 & 0.231 & 0.171 \\
\hline P:V, dol./calc. & 0.201 & 0.197 & 0.245 & 0.177 \\
\hline Cultivar Mean & $0.196 \mathrm{~b}$ & $0.193 \mathrm{~b}, \mathrm{c}$ & $0.232 \mathrm{a}$ & $0.182 \mathrm{c}$ \\
\hline
\end{tabular}

Table 5.2.b. Magnesium in rose petals at the time of cutting as a $\%$ of the dry weight. No significant evidence of a media effect was found, but there was significant evidence of a cultivar effect. Different letters beside the cultivar means indicate a significant difference at the $p=0.05$ level. 


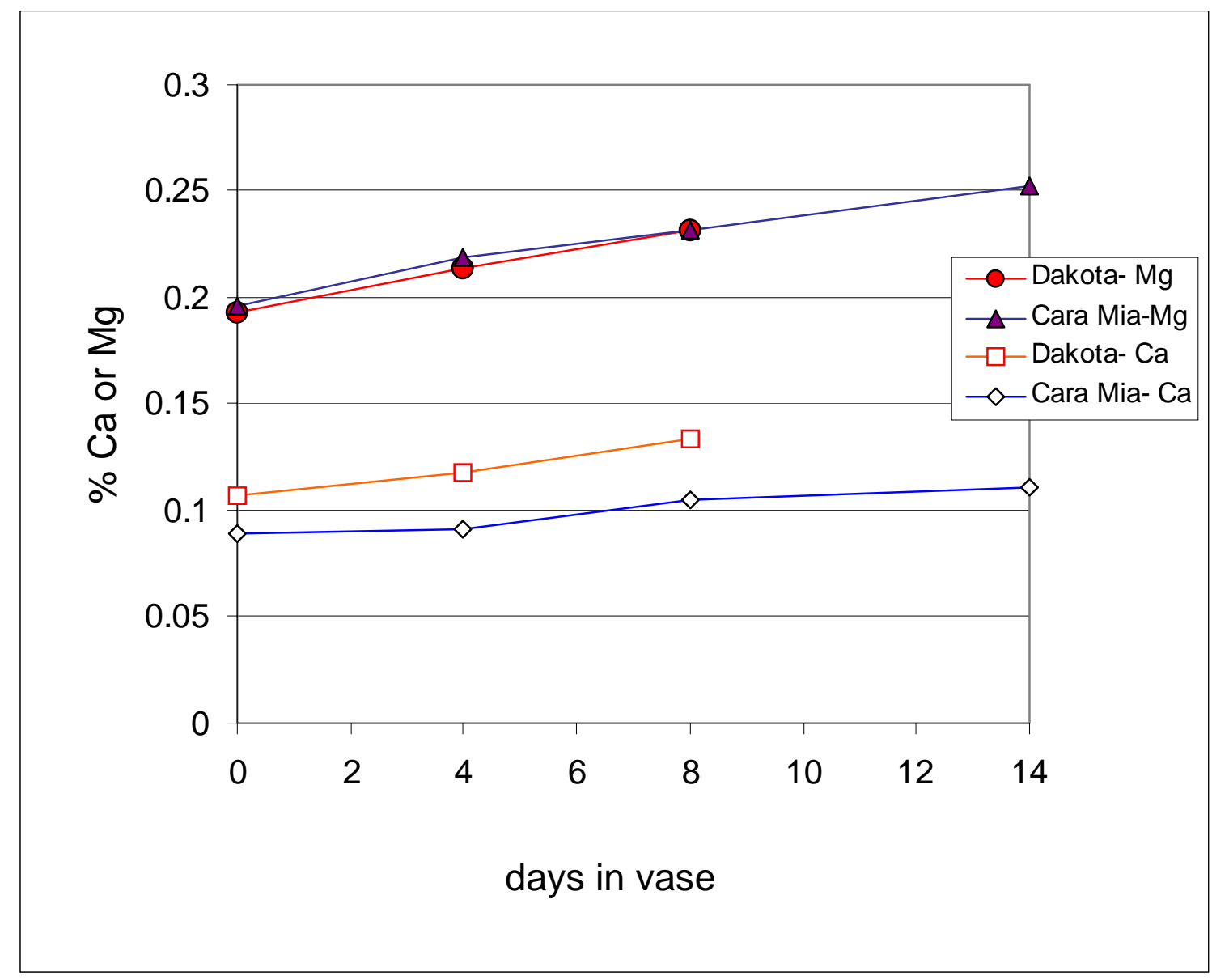

Figure 5.3. Percent $\mathrm{Ca}$ and $\mathrm{Mg}$ in the petal tissue of Cara Mia and Dakota roses. Amounts are given as a $\%$ of the dry weight. Both calcium and magnesium are increasing over the vase life. $\mathrm{Ca}$ is significantly greater in Dakota petals than in Cara Mia petals. No cultivar difference in magnesium was found; however, there was significant evidence of a media effect on magnesium content (see Fig. 5.5) 


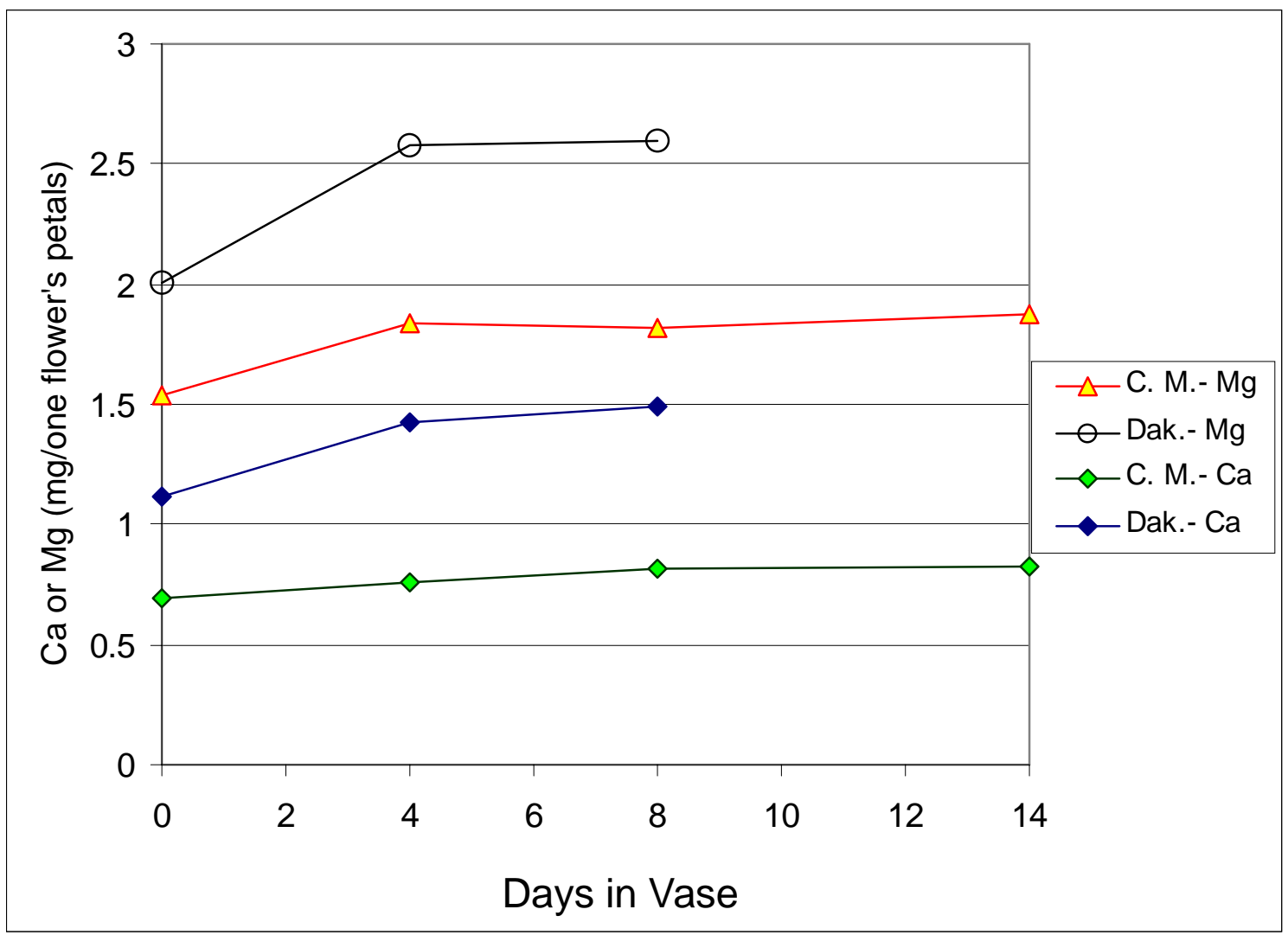

Figure 5.4 Percent $\mathrm{Ca}$ and $\mathrm{Mg}$ in the petal tissue of Cara Mia and Dakota flowers. Amounts are given as mg from the petals of one flower. $\mathrm{Ca}$ and $\mathrm{Mg}$ are both increasing significantly over the vase lives. This increase occurs faster in Dakota than in Cara Mia. The overall differences between cultivars is significant, but not important since the flowers of Dakota are just larger. (Figure 5.3 shows a real difference between the calcium levels of these two cultivars.) No evidence of a media effect was found with respect to Ca. MSE for the calcium measurements $=7.85 X 10-3$; for $\mathrm{Mg}, \mathrm{MSE}=1.166 \mathrm{X} 10-2$. 

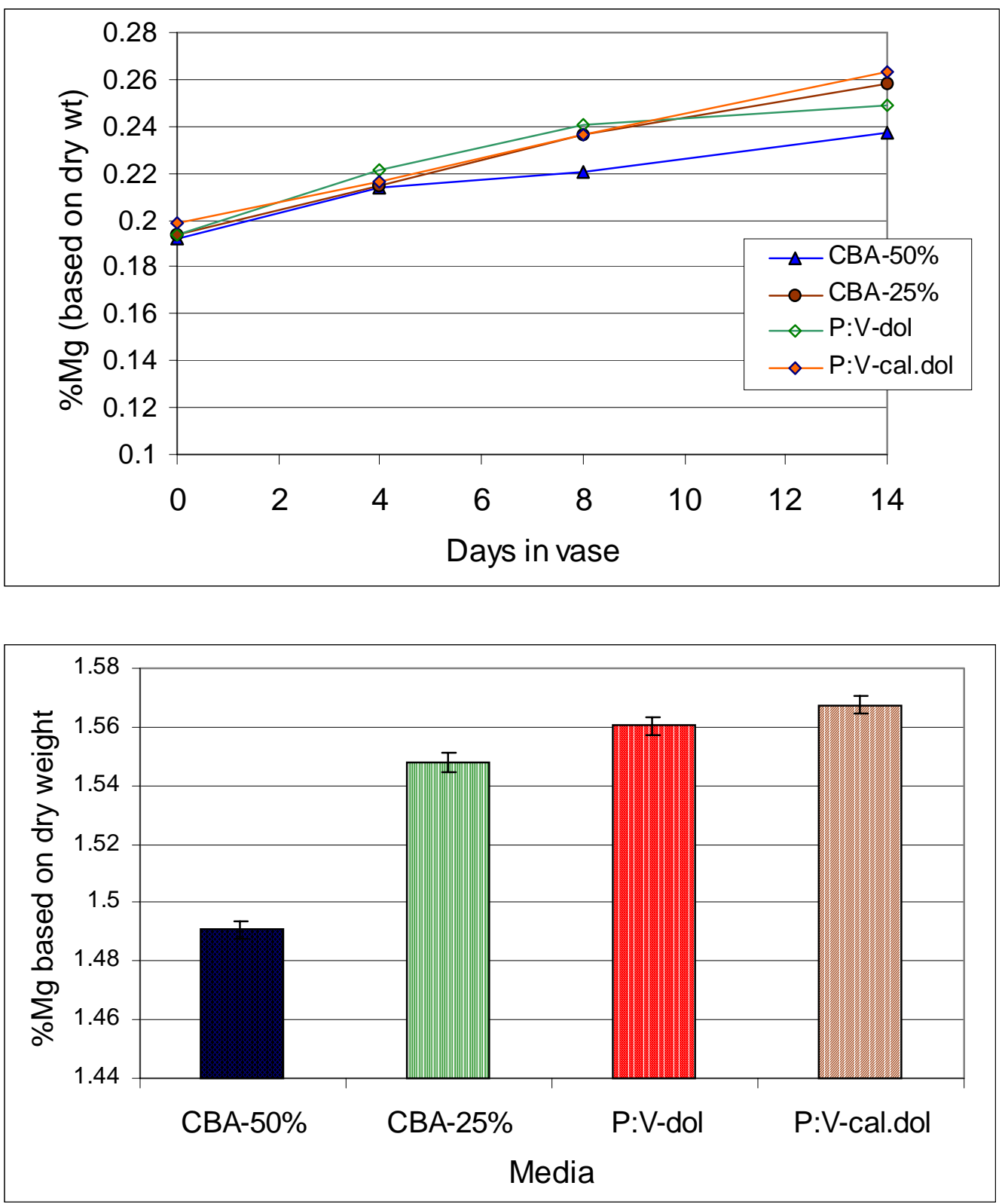

Figure 5.5. Magnesium in the petal tissue of Cara Mia and Dakota roses over their vase lives (top graph) and averaged over all vase times and both cultivars (bottom graph). A significant difference due to media was found at the $p=0.01$ level. Error bars indicate $+/-2$ s.e. 


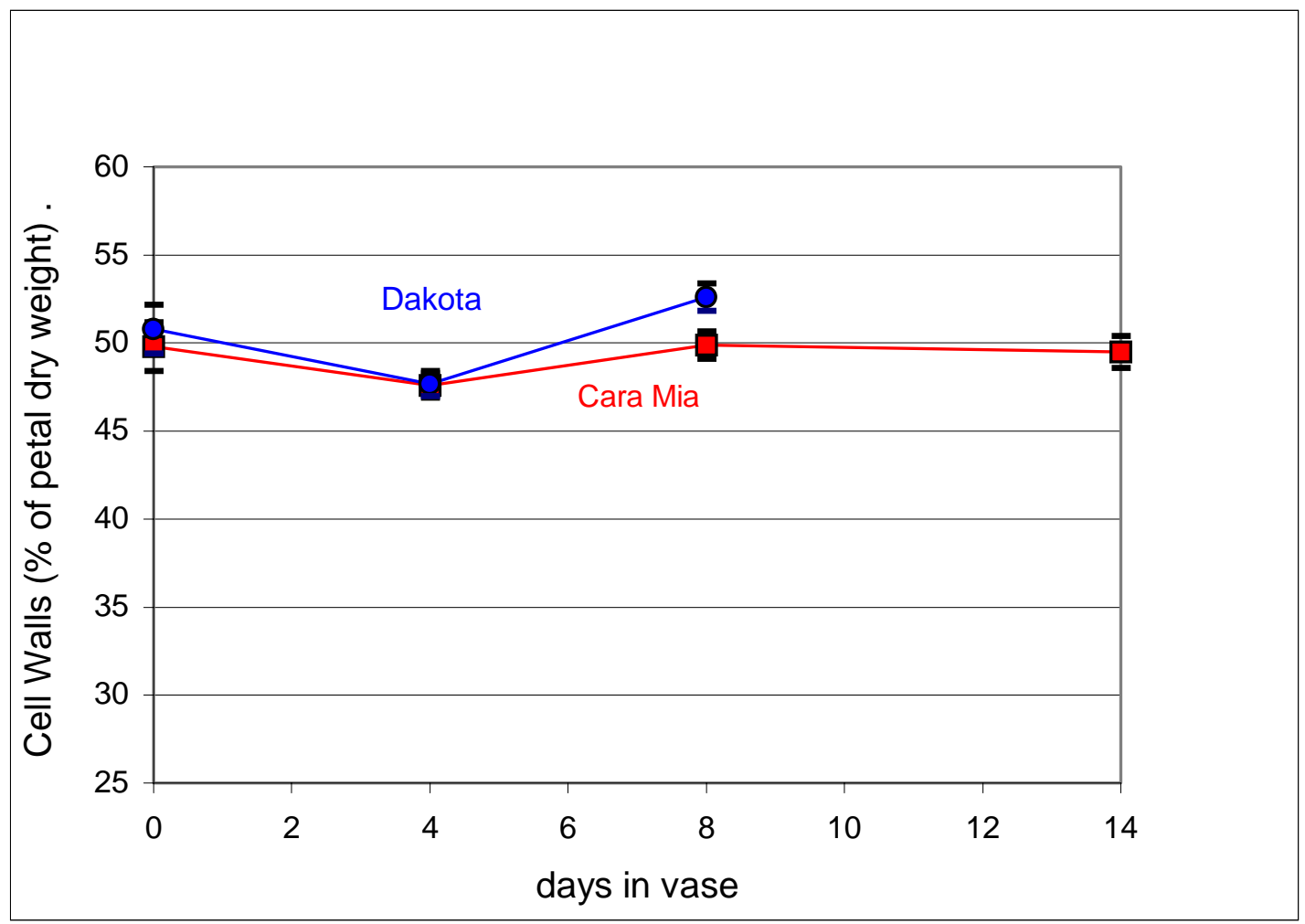

Figure 5.6. Dry weight of the cell wall fraction isolated from petal tissue as a $\%$ of the petal dry weight. Error bars show $+/-2$ s.e. The decrease shown around day 4 may simply reflect an increase in the dry weight that occurs at this time, since these measurements are based on dry weight. No media effect was found. Dakota has a significantly higher amount of cell wall material than Cara Mia. Each point on the graph is the average of 12 separate measurements, 3 from each media. 


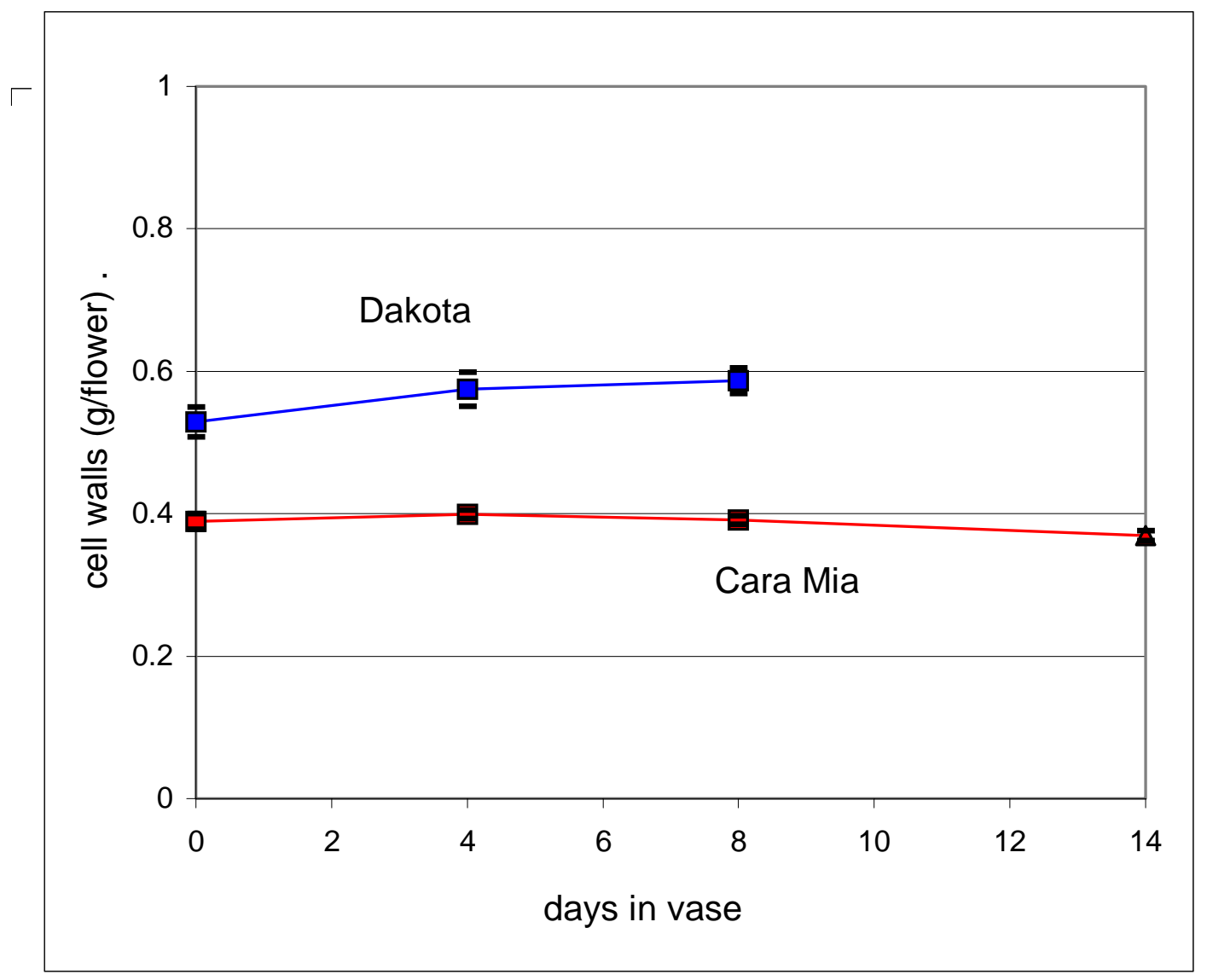

Figure 5.7. Dry weight of the cell wall fraction isolated from petal tissue given in $g$ per one flower's petals. Error bars show $+/-2$ s.e. The way that the amount of cell wall material changes over the vase life is different in these two cultivars. Dakota gains some cell wall material near the beginning of its vase life, while Cara Mia shows some loss of cell wall material near the end of its vase life. Each point on the graph is the average of 12 separate measurements, 3 from each media. 


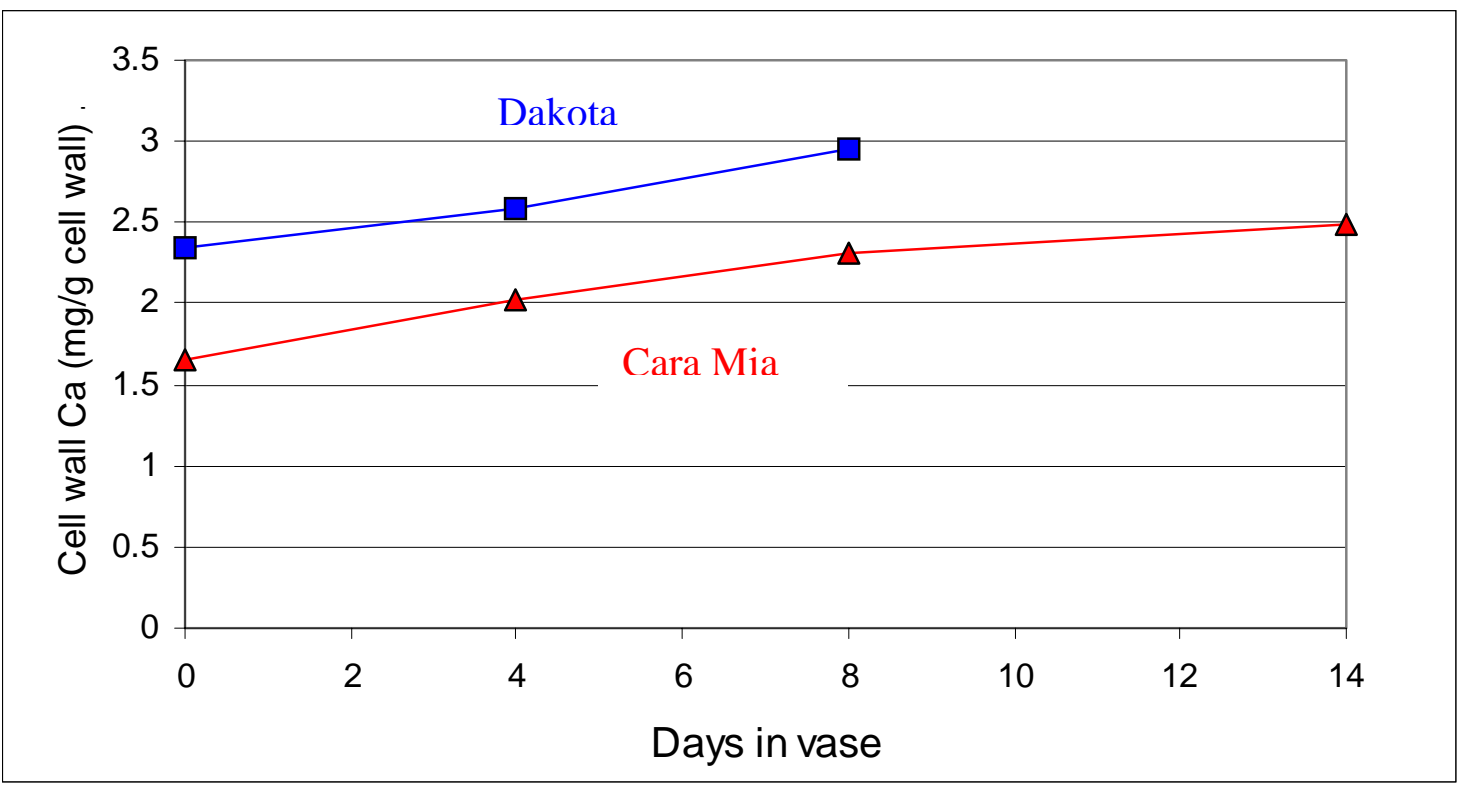

Figure 5.8. Cell wall calcium in mg per $\mathrm{g}$ of cell wall dry weight. A difference was found due to cultivar with Dakota having more calcium per $g$ of cell wall than Cara Mia . Calcium is increasing in the cell wall fraction over the vase life in the same way for both cultivars. Each point is the average of 12 measurements.

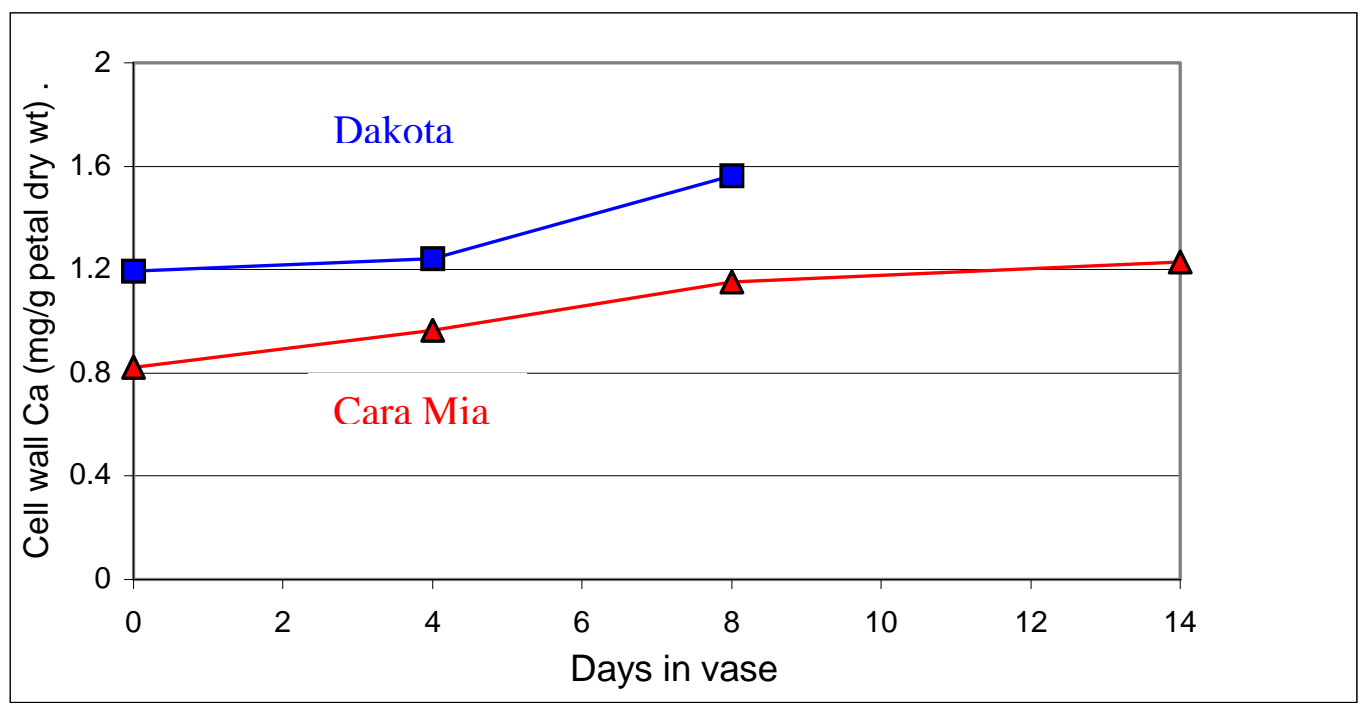

Figure 5.9. Cell wall calcium expressed as $\mathrm{mg}$ of calcium per $\mathrm{g}$ of petal dry weight. Dakota has a greater amount of Ca per $\mathrm{g}$ of petal than Cara Mia. No significant difference due to media was found. Calcium is increasing over the vase life for both cultivars in the same way. Each point is the average of 12 measurements. 


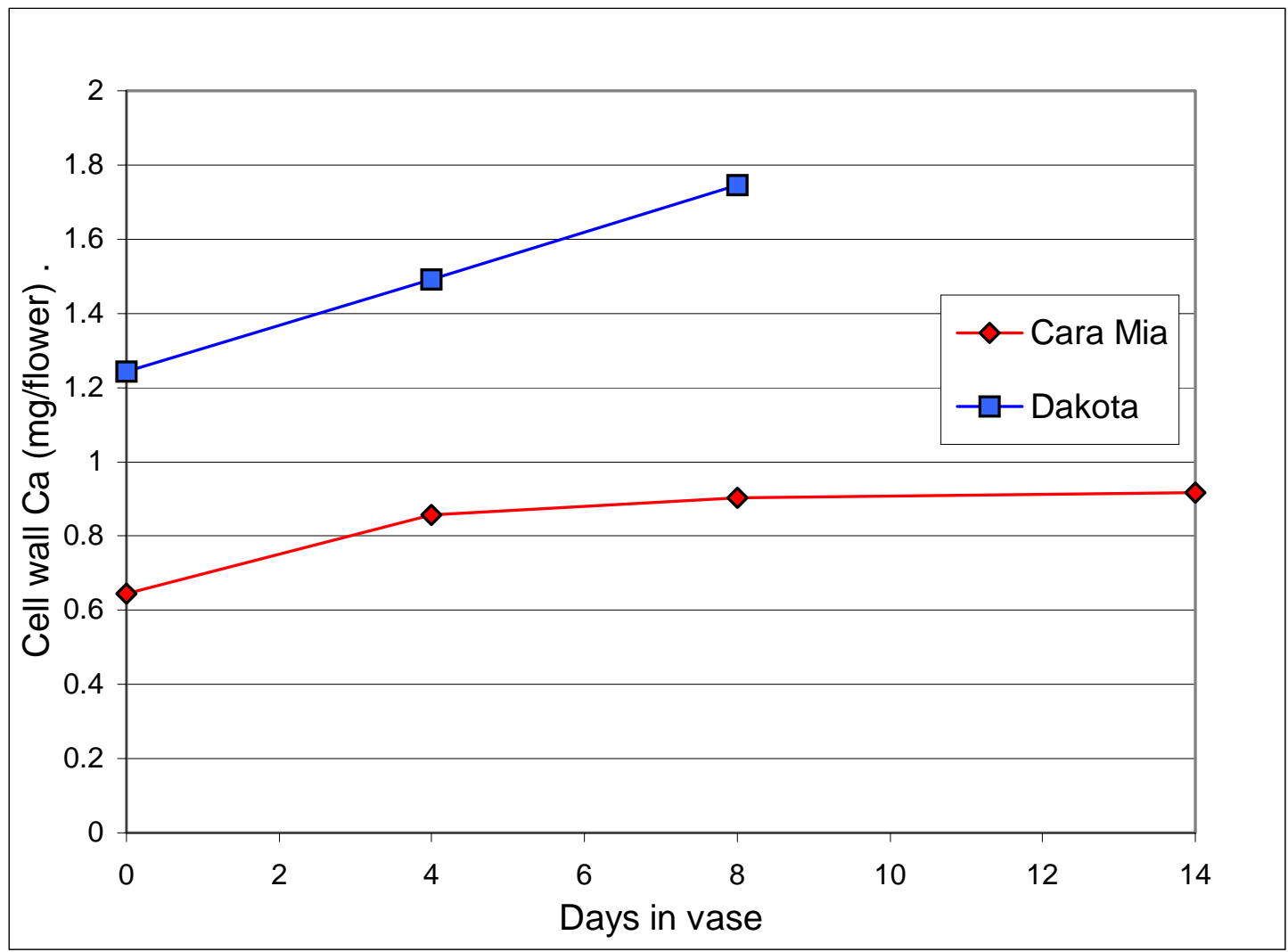

Figure 5.10. Cell wall calcium expressed as $\mathrm{mg}$ of calcium per one flower's petals. There is, statistically, a difference due to cultivar with Dakota having more Ca, but this is not of interest since Dakota flowers are simply larger. No difference due to media was found. Ca is increasing over the vase life in the same way for both cultivars. 


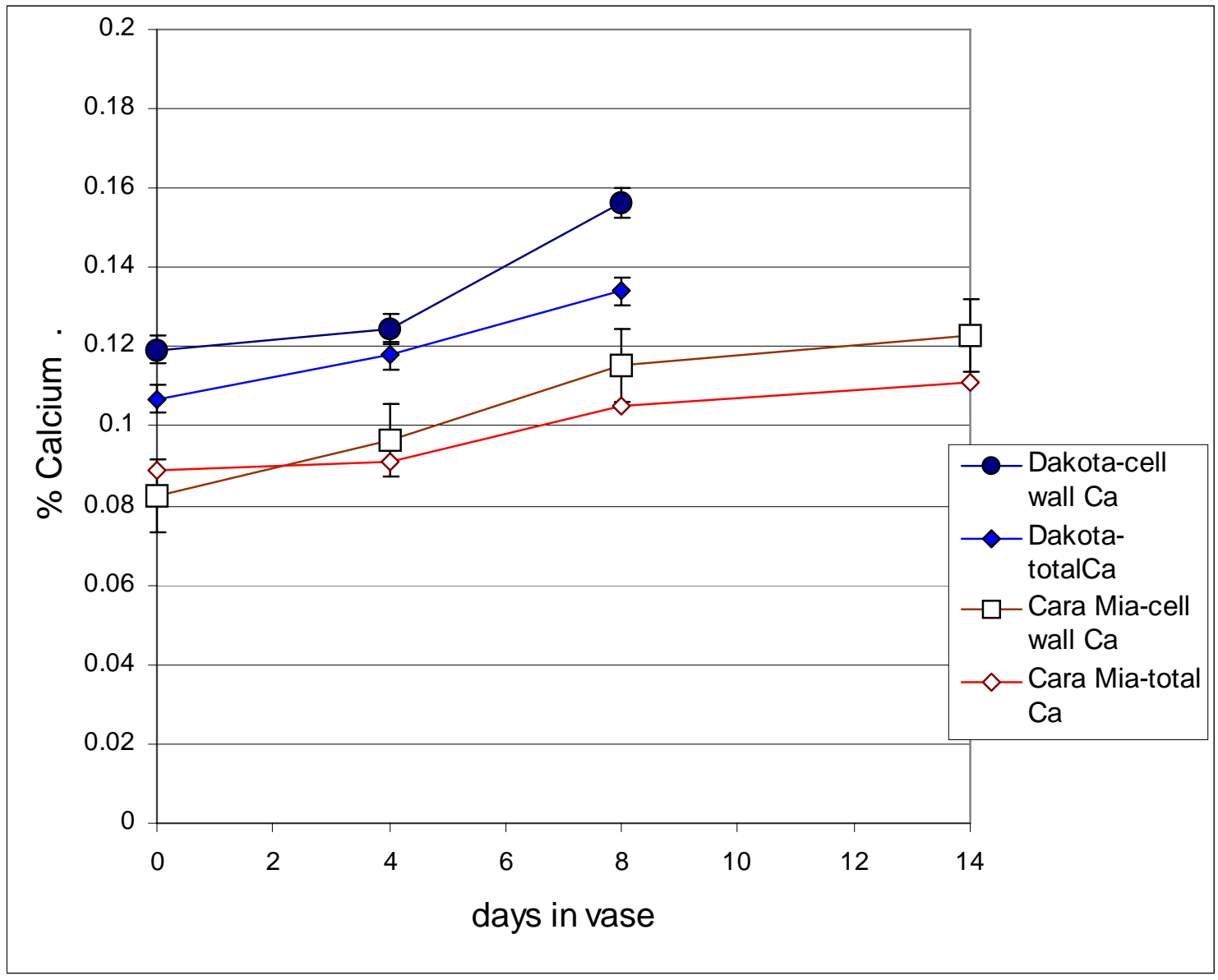

Figure 5.11. Percent calcium in petal tissue of Cara Mia and Dakota roses. Data is shown for total calcium from petal tissue (as a \% of petal dry weight) and for calcium from the cell walls from that petal tissue (also as a $\%$ of petal dry weight). Error bars are $+/$ - one s.e. Please see text for a discussion of this apparent contradiction. 


\section{Discussion}

A higher amount of available $\mathrm{Ca}$ in the media was related to an increased amount of calcium in the leaf tissue of roses grown in that media (Figure 5.1) and a longer vase life (See Figure 5.2). In the two peat:vermiculite media, media 3 and 4, the only difference was the type of lime used. This points to differences in calcium availability as the cause of vase life differences, instead of some other factor such as $\mathrm{pH}$ or another nutrient. Calcium and magnesium are thought to compete for uptake sites on the plant roots (Nelson, 1998). A ratio of 3:1 calcium to magnesium is considered a good ratio in the soil solution. Below this, calcium uptake may be inhibited by magnesium and calcium deficiency can result (Nelson, 1998). In media 3, which has only dolomitic lime, the calcium to magnesium ratio is lower than in media 4 (dolomitic plus calcitic) and roses grown in this media have lower calcium amounts in the leaf tissue.

How is calcium extending rose vase life? The amount of calcium in the petals themselves has not increased. In fact, the calcium amounts in petal tissue are extremely low - often less than $0.01 \%$ - less than one tenth that of the leaves. Starkey and Pedersen (1997) reported calcium levels in rose flowers that were on the order of one half that of the leaves. These measurements were taken on the whole flower bud, though, and rose flower parts other than petals have a much higher calcium level.

The positive effect of calcium in this study, given that petal calcium was not increased, may be exerted on the leaves, which in turn improve the quality of the flower. Or the effect may concern the xylem or stem tissue. The research presented here does not answer this question.

It is important to note that higher leaf tissue calcium lead to longer vase life only within each cultivar. Between cultivars, at least for the four rose cultivars used here, it seems that roses "requiring" less Ca may have longer vase lives. We can propose an explanation for this. It has been suggested that one cultivar may need less $\mathrm{Ca}$ than another because it has a lower number of exchange sites in the cell wall (Marschner, 1995). In a low-transpiration organ like a flower, calcium amounts reaching the tissue via the xylem are low. It may be an advantage to require less calcium in this case. More data is needed to bear out this relationship. 
It can be seen in Figures 5.3 and 5.4 that both total calcium and total magnesium are increasing over the vase life of the rose. At time 0 , the roses were cut and placed in distilled water. Any additional calcium or magnesium accumulating in the petal tissue while roses were held in the vases must be translocated to the petals from the leaves or stem. Magnesium is known to be translocated in part through the phloem and may be reaching the petals this way. However, calcium is not thought to be translocated via the phloem. (Because of its role as a second messenger, amounts of symplastic calcium are very tightly controlled, and the phloem is essentially a part of the symplasm.) We propose that calcium is being translocated to the petals through the xylem and that its source is the apoplastic spaces of the rest of the stem.

By comparing the amounts of total calcium per mg of petal dry weight with the amounts of cell wall calcium per mg of petal dry weight (Figures 5.3 and 5.9 have been combined as Figure 5.11), it can be seen that all of the measurable calcium in petals is located in the petal cell walls. (In fact, these two sets of curves overlap, with the cell wall calcium measurements tending to be higher. Of course, this is impossible, but the differences may be explained by possible methods differences: the drying method that was used may produce whole petal samples that may have slightly different residual water content than cell wall samples simply due to their differences in composition. Also, dryashing of these two different sample types may differ in level of completeness or charring.) It is not surprising that virtually all of the calcium is located in the cell walls. The petals contain very low quantities of calcium, and it is doubtful that there would be any need for storing calcium in cell organelles.

Figure 5.8 shows that Dakota petal cell walls have more calcium in them (per $\mathrm{g}$ cell wall) than Cara Mia petal cell walls. This is the same pattern that was found in the leaf tissue (albeit at a level of 12 times more) and may reflect cultivar differences in the CEC of the petal walls.

The amount of cell wall material was extracted as the AIR fraction. Only very small differences were found in this fraction when the two cultivars were compared. Figure 5.6 shows cell wall material from the two cultivars on a dry weight basis. This fraction made up about $50 \%$ of the petal dry weight. The dip in the graph (Figure 5.6) at day 4 can be accounted for by considering the changes in dry weight at that period. The 
two cultivars are very similar in the proportion of petal dry weight that was in the cell wall fraction. A small but statistically significant difference was found overall, indicating that the proportion may be slightly larger in Dakota. Figure 5.7 shows the amount of cell wall material on a per petal basis. Any changes in amount as vase life proceeds should be evident here. Statistical analysis showed that the amount was changing over the vase life and that the change differed for the two cultivars. In Dakota, cell wall amounts appear to increase during the first few days in the vase - as the rose is expanding. (A similar small increase can be seen for Cara Mia, but this was not statistically significant.) Cara Mia cell wall amounts decreased near the end of the vase life. Dakota petals were not measured at this time because they were past the end of Dakota's vase life and, many times, they had already abscised.

In a study of carnation petals, deVetten and Huber (1990) found that the amount of cell wall material increased until about the time when flowers were fully opened, then decreased until the end of the vase life. The changes were more pronounced in carnations than those found here for roses. 


\section{Chapter 6 - Membrane Leakage}

\section{Introduction}

Senescence can be considered a natural, controlled process. As this process proceeds, changes occur in the plant cell membrane. In petal tissue, some of these changes have been documented. Total membrane protein decreases as petals senesce. Phospholipid content also decreases as does membrane fluidity (Borochov et al., 1982). It has been shown that the decrease in phospholipids results in an increase in sterol to phospholipid ratio in the plasma membrane and this results in a decrease in membrane fluidity (Borochov et al., 1982). The decrease in phospholipid was further shown to be the result of both a decrease in synthesis and an enhanced degradation by phospholipase A. (Free sterol level remained constant.) Since senescence is considered a natural, programmed process, these changes must be, in part, under genetic control. But evidence has been presented that these changes are also affected by other factors. One such factor that has been shown to affect these membrane changes is calcium.

The physiological role of calcium in delaying senescence has not been fully explained, but it is thought to include interactions with the cell membrane. Calcium is thought to bind the negatively charged polar heads of phospholipids in the membrane, forming bridges, and also to cross-link the membrane phospholipids to membrane proteins (Arora, 1990). These linkages stabilize the membrane. Increased Ca in the tissue has been shown to decrease leakage of $\mathrm{K}^{+}$and other compounds (Arora, 1990) (Torre et al., 1999). These effects may be due to the stabilization of the membrane or may be due to a more specific effect of $\mathrm{Ca}$ on plasma membrane $\mathrm{H}^{+}$-ATPase. $\mathrm{H}^{+}$-ATPase activity has been shown to decrease during senescence and this decrease is delayed by calcium (Torre et al., 1999). The exact mechanism is not understood. Calcium has been shown to delay the decrease in membrane protein and phospholipid content that typically occurs as the rose senesces (Itzhaki et al., 1998) (Torre et al., 1999). The change in membrane structure as rose petals senesce is paralleled by a loss of membrane integrity, measured as solute leakage from the petals (Borochov et al., 1982). Membrane leakage was also found to be delayed by increasing the calcium in the petal tissue (Torre et al., 1999). 


\section{Materials and methods}

\section{Plant material}

Two rose cultivars, Rosa $x$ hybrida cvs Dakota, and Cara Mia, were used for this study, to represent short and long vase-lived cultivars, respectively. Roses used for this experiment were the second crop taken from the bushes and cutting was done from September 23, 1998 to October 15, 1998.

All roses were cut in the morning and handled in the same way as described for crop 1 (see Materials and Methods, Chapter 2). After conditioning overnight, roses were transferred to the light bench in the lab and randomly assigned to a vase life time period. As for crop 1 , roses were held at $22^{\circ} \mathrm{C}$ and $60 \% \mathrm{RH}$ with a $12 \mathrm{~h}$ photoperiod of $15 \mu \mathrm{mol} \mathrm{m} \mathrm{m}^{-2} \mathrm{~s}^{-1}$ light from cool white fluorescent lights. Water was changed and roses recut every two days.

\section{Membrane leakage}

Membrane leakage was measured using a modification of Arora's method (Arora et al., 1992). Two 2-petal samples were taken from the second whorl of petals from each rose after a given number of days in the vase. Each 2-petal sample was weighed, cut into strips, and rinsed in dd. $\mathrm{H}_{2} \mathrm{O}$. The samples were then placed in $20 \mathrm{ml}$ of dd $\mathrm{H}_{2} \mathrm{O}$ and vacuum-infiltrated twice, for three minutes each time, to assure that water was in continuous contact with the petal tissue. Samples were then shaken on a G 10 Gyrotary shaker (270rpm) for 3 hours at room temperature. The water from this incubation was saved (termed the leakage fluid) and the petals were placed in a fresh aliquot of dd. $\mathrm{H}_{2} \mathrm{O}$ and heat-killed by autoclaving for $30 \mathrm{~m}$. The solution from this autoclaving was termed the heat-killed fluid. Both solutions were brought to room temperature and measured for electrical conductivity with a YSI Model 35 conductivity meter. Also, the solutions were filtered through Whatman 42 filter paper and measured for calcium and potassium content on an atomic absorption spectrophotometer. 
Electrolyte leakage (E.L.) and leakage of $\mathrm{K}^{+}$and $\mathrm{Ca}^{2+}$ was expressed as a $\%$ of the total from heat-killing. $\mathrm{K}^{+}$and $\mathrm{Ca}^{2+}$ from leakage and from heat-killing were also calculated as the amount in grams per dry weight of the petal tissue and the amount in grams per petal.

\section{Statistical Analysis}

Leakage data were analyzed using the GLM procedure in SAS as a split-split plot over time with cultivar as the main plot treatment arranged in blocks. Media was a subplot treatment arranged in a Latin square and day was a sub-sub plot treatment, which was treated as a third order polynomial. The statistical model is shown in Appendix Table A.6.1.

\section{Results}

\section{Leakage Study}

The fact that media did not affect Ca content in the petal tissue (see Table 5.2, Chapter 5) was born out in the leakage data presented here - no media effect was found. The reporting of these results, therefore, concentrates on differences due to the cultivar of rose. Cara Mia was used as a long-lived cultivar and Dakota was used as a short lived cultivar.

Electrolyte leakage increased over the vase lives of the roses as they senesced. Both Dakota and Cara Mia roses followed the same pattern of leakage increase (no cultivar*media interaction), even though their vase lives were so different (Figure 6.1). The curve was a third order response. While no evidence of a difference in shape of the curve was found, Cara Mia's curve was significantly higher than Dakota's. In other words, Cara Mia had higher levels of free ions in the apoplast at any given vase life than Dakota.

$\mathrm{K}^{+}$leakage generally reflected electrolyte leakage. Palta et al. (1977) found this to be true of onion skins as well, with $\mathrm{K}^{+}$being the main cation in the leakage fluid. Figures 
6.2 and 6.3 compare the quantity of $\mathrm{K}^{+}$that "leaked" - or was free in the apopast - and the total quantity of $\mathrm{K}^{+}$that was released upon heat-killing the petal tissue as vase life progressed. Both of these quantities increase over the vase life.

A similar pattern was found for $\mathrm{Ca}^{2+}$. The amounts of $\mathrm{Ca}^{2+}$ that were free in the apoplast increased over the vase life for both varieties, but the increase was greater for the longer-lived Cara Mia roses (Figure 6.4). Figure 6.4 also shows the amount of $\mathrm{Ca}^{2+}$ released upon heat killing. It does not include all of the calcium present in the petal tissue, as can be seen by a comparison to the "total calcium" amounts (from dry-ashing) (see Figure 5.3, Chapter 5). [It must be noted that these two sets of measurements can only be indirectly compared because they come from two different harvests of the same plants. However, these harvests showed no significant differences in either vase life or leaf tissue analysis. And petal tissue analysis at cutting (day 0) was the same for both harvests.]

This same data is also graphed on a per petal basis (Figure 6.5). Here, since changes in dry weight are not confounding the results, it can be seen that calcium released by heat-killing the petal tissue is decreasing over the vase life (Figure 6.5.B). Figure 6.6 is a "speculative" graph and will be discussed in the next section. 


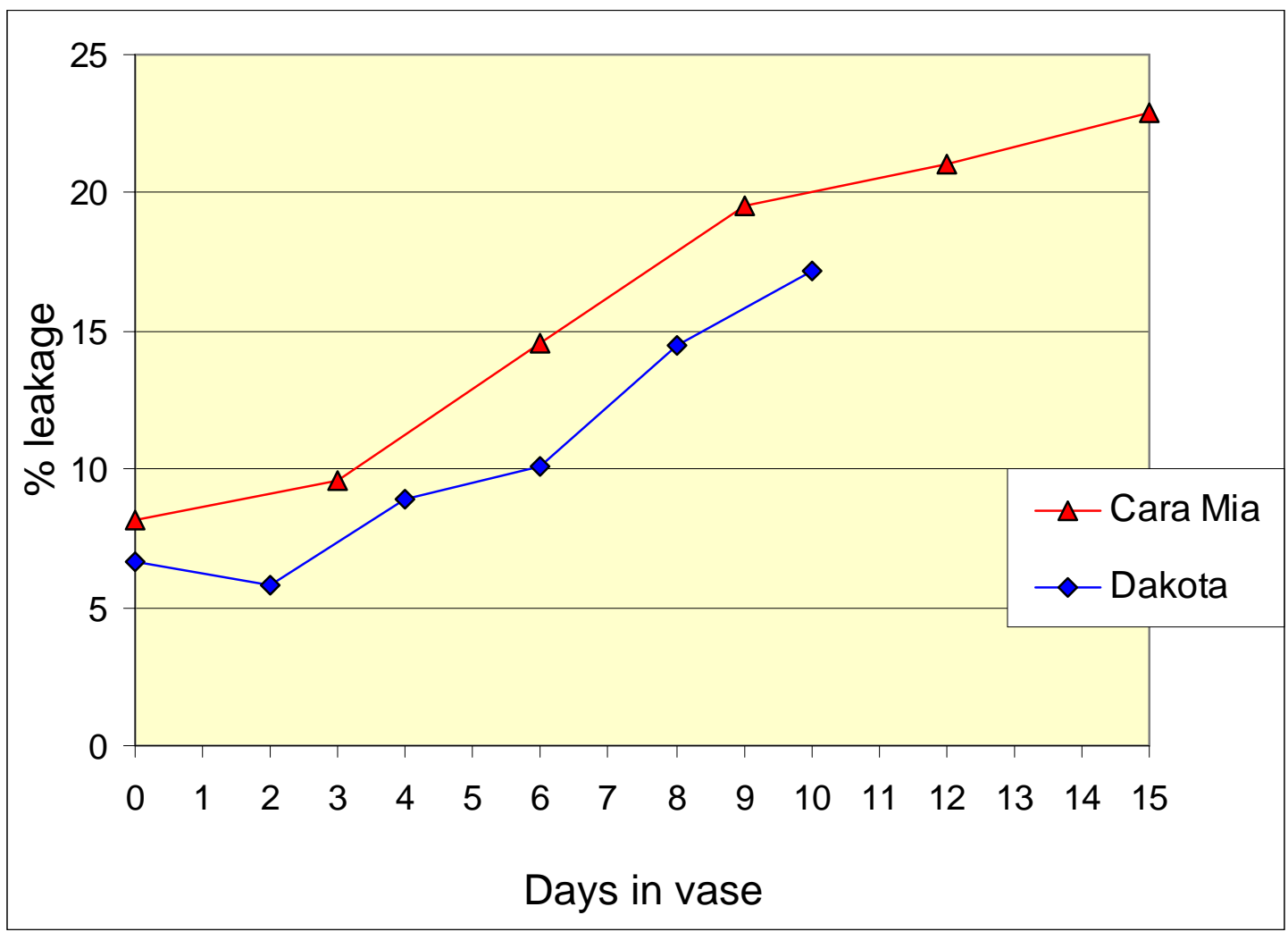

Figure 6.1. Leakage from petal tissue of Cara Mia and Dakota roses over their vase lives. The curves are third order and no evidence was found of a difference in the shapes of the two curves. Cara Mia had a higher level of leakage overall than Dakota. $(p=0.05, \mathrm{MSE}=4.681)$ 


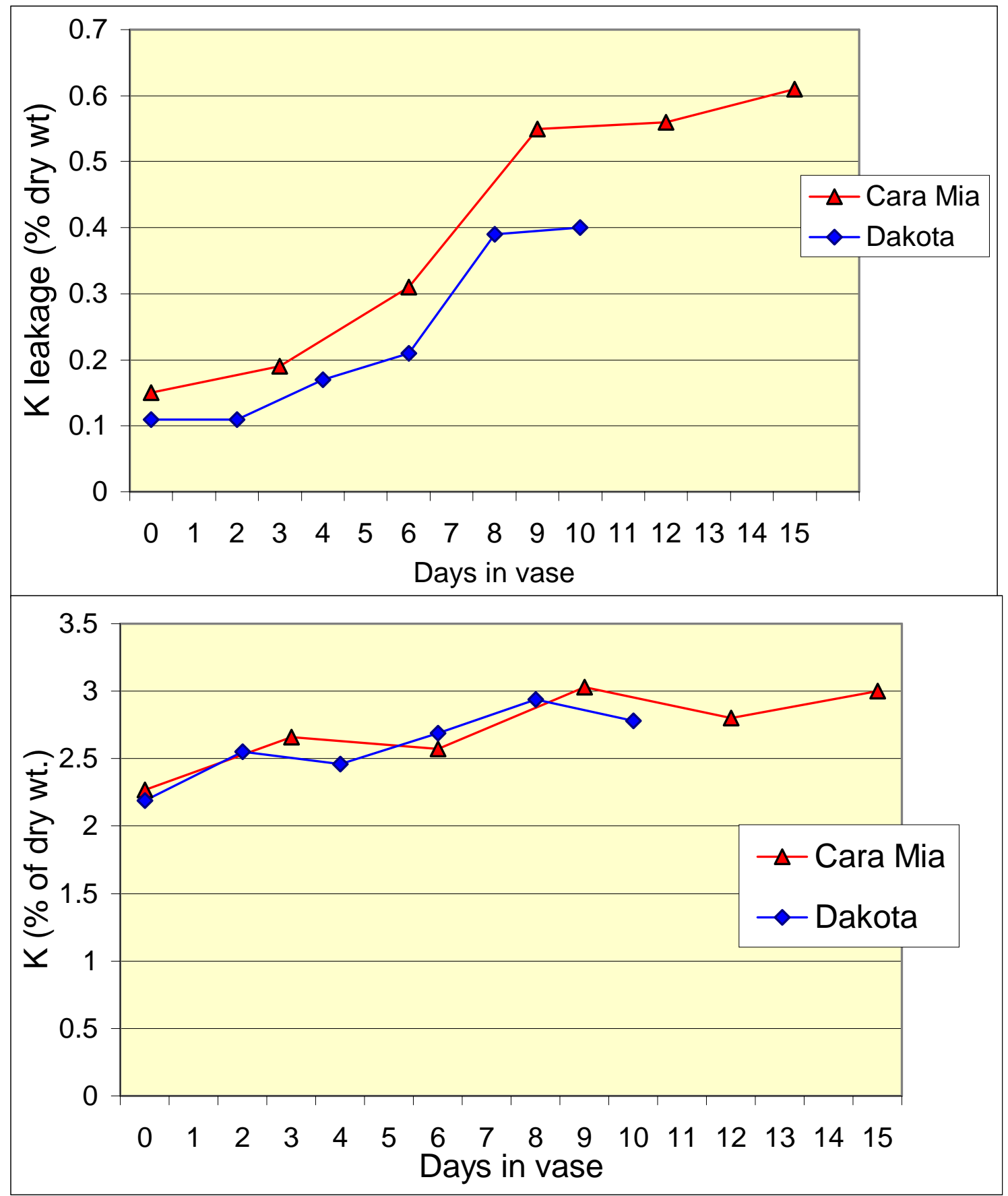

Figure 6.2. Top. Potassium leakage from petal tissue. The response is a third order curve, and there is no evidence of a difference between cultivars. MSE=5.77X10-2.

Bottom. Potassium released from heat killing. $\mathrm{K}$ is increasing over time in the same way for both cultivars. MSE=7.79X10-2. In both graphs, $\mathrm{K}$ is expressed as a $\%$ of the dry weight. 


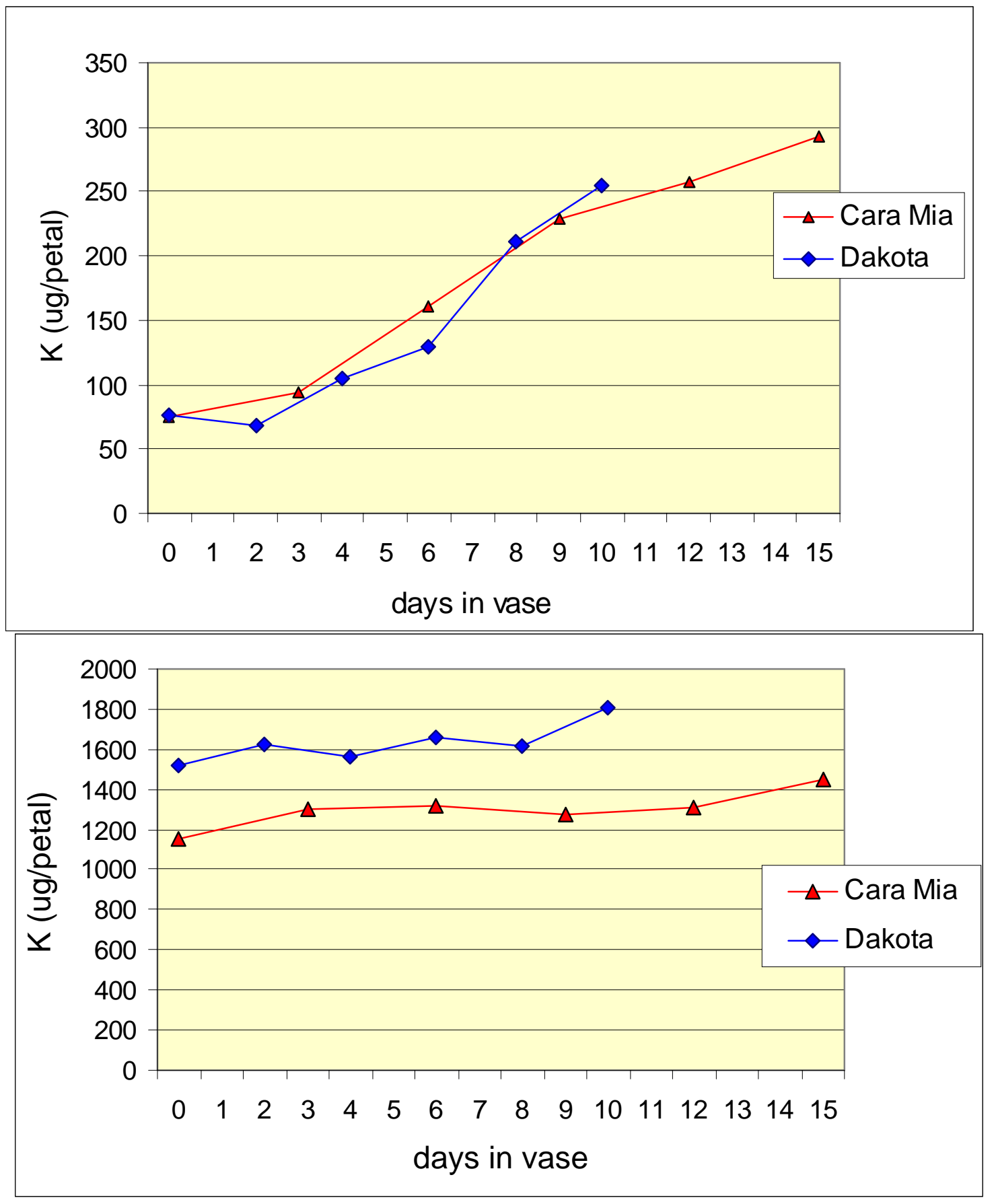

Figure 6.3. Top. Potassium leakage from petals. The response is a third order curve, and there is no evidence of a difference between cultivars. Bottom. Potassium released from heat killing. $\mathrm{K}$ is increasing over time in the same way for both cultivars. $\mathrm{K}$ from heatkilling is greater in Dakota than in Cara Mia (but Dakota petals are larger). In both graphs, $\mathrm{K}$ is expressed as ug per petal. 

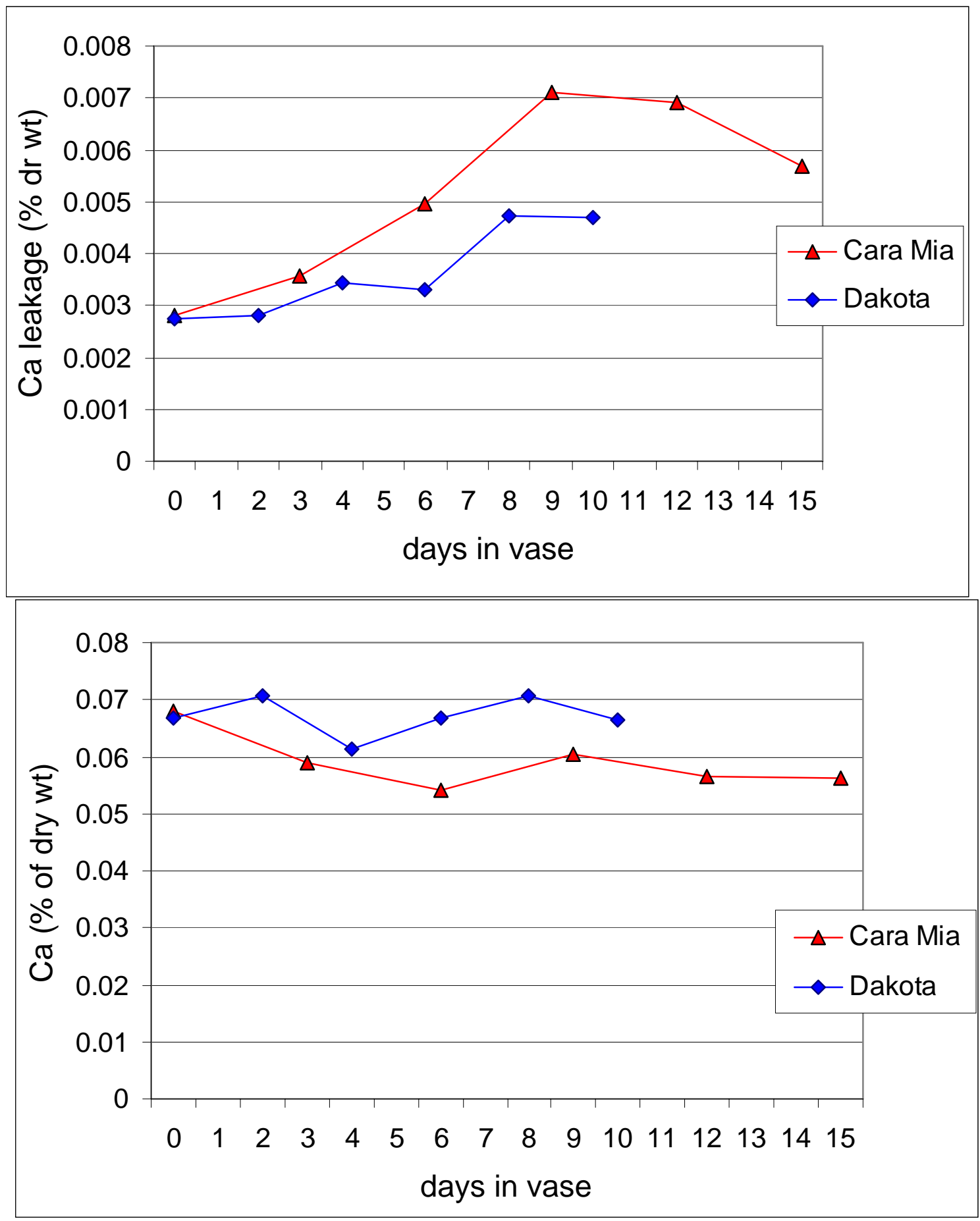

Figure 6.4. Calcium leakage from petals (top) and calcium released from heat-killing (bottom). Both graphs are expressed as a \% of the dry weight. Leakage calcium is increasing for both cultivars, and this increase is greater for Cara Mia. For heat-killing-released calcium, no evidence of a media effect was found, and no evidence of a decrease over time was found. 

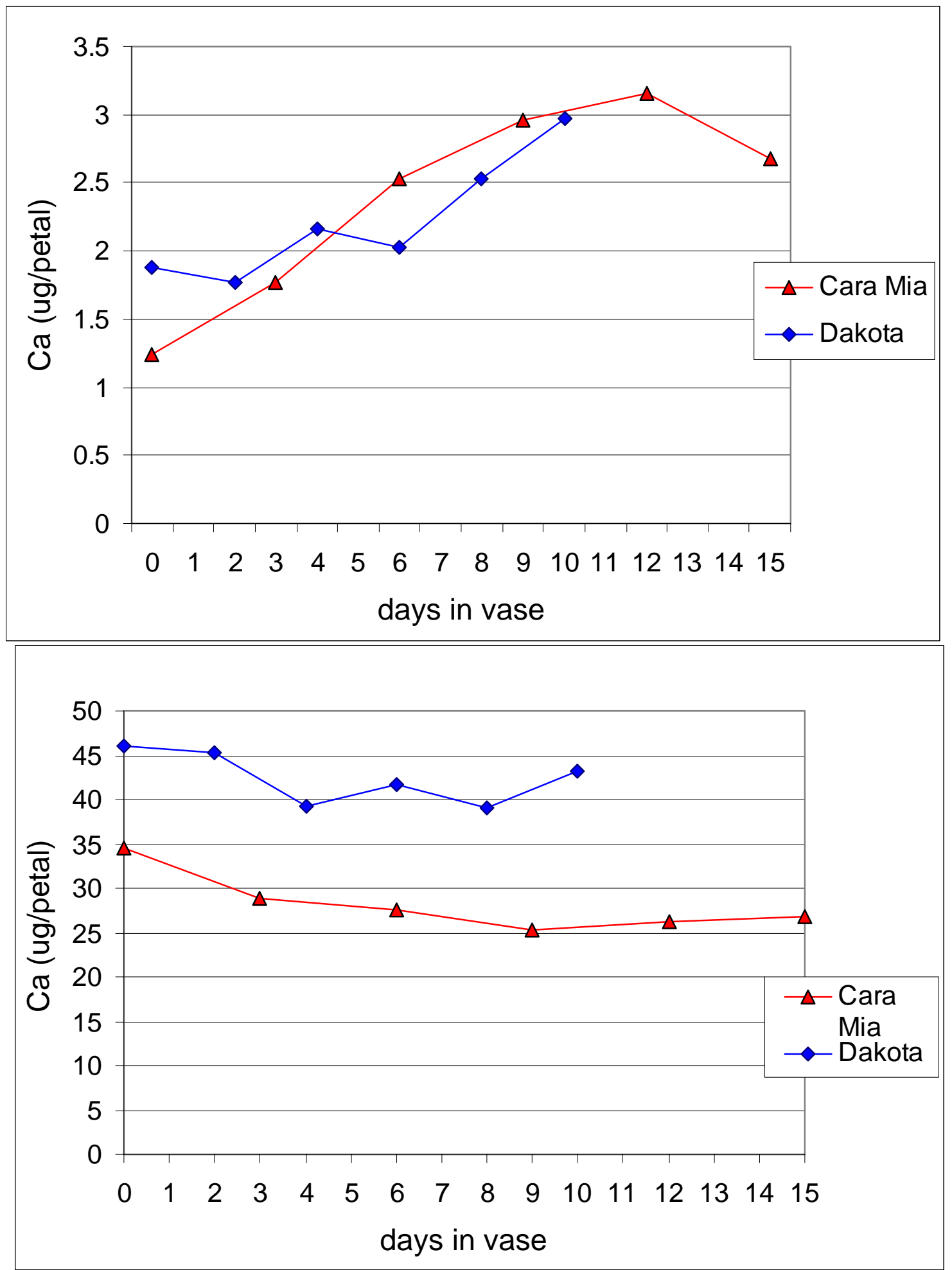

Figure 6.5. Calcium leakage from petal tissue (A) is increasing for both cultivars over the vase life, and calcium released from heat-killing(B) is decreasing over the vase life for both cultivars. Both graphs are expressed as ug per petal. 


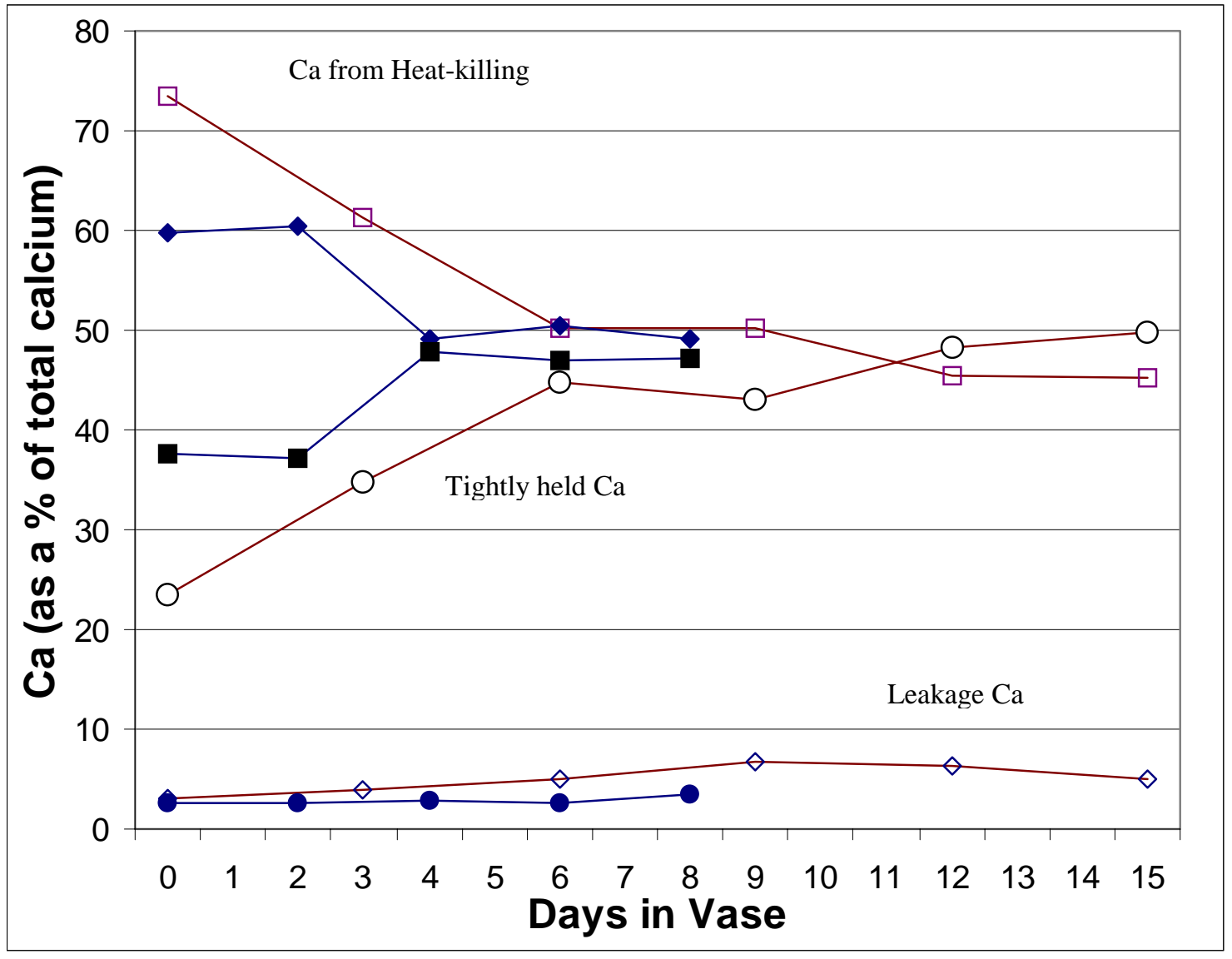

Figure 6.6. Calcium allocation into different fractions of the petal tissue of Cara Mia and Dakota roses. Leakage calcium is the calcium that was free in the apoplast. Calcium from heat-killing was the calcium released when the petals were autoclaved in distilled water. Tightly held calcium was the calcium that remained in the autoclaved petal tissue. This last quantity was calculated by subtracting the sum of the first two quantities from the total calcium. This graph is meant to show the trends in calcium allocation only. Points are given as a $\%$ of total $\mathrm{Ca}$ and are an average of 12 measurements each. Open points show Cara Mia data. Closed points show Dakota. 


\section{Discussion}

A higher amount of available $\mathrm{Ca}$ in the media was related to an increased amount of calcium in the leaf tissue of roses grown in that media and a longer vase life (see Chapter 2) but the amount of calcium in the petals themselves did not increase. In fact, the calcium amounts in petal tissue are extremely low - often less than $0.01 \%$ - less than one tenth that of the leaves (see Chapter 5).

It is important to note that higher leaf tissue calcium paralleled longer vase life only within each cultivar. To shed some light on cultivar differences in rose vase life, Cara Mia and Dakota roses were compared with respect to electrolyte leakage over their vase lives. Cara Mia, again, was used as the long vase life rose (14.3 d) while Dakota represented a shorter lived ( $8.6 \mathrm{~d}$ ) cultivar. Both cultivars followed the same kinetics of electrolyte leakage over their vase lives (Figure 6.1). And Cara Mia had a consistently higher leakage over all. This is unexpected because increase in leakage is usually measured as an indicator of senescence. If that were so, then it would be expected that the increase in leakage would occur sooner and/or to a greater extent in Dakota, the short lived cultivar. It must be concluded, at least for these two cultivars, that leakage is not correlated with senescence.

Measuring the potassium and calcium in the leakage fluid from this study allows us to quantify the amounts of each of these nutrients that was free in the apoplast at the time of measurement and/or was released into the apoplast during the incubation period.

It is generally believed that the increase in electrolytes in the leakage solution is an indicator of membrane deterioration. By using the term leakage, we imply an uncontrolled passage of ions through the membrane. This phenomenon is clear in freezing injury where cell damage and death are visible even to the eye as water-soaked and browned areas (Lim et al., 1998). However, no obvious outward signs of cell death are evident in roses until the very end of their vase lives. Changes in the composition and fluidity of the membrane have been shown to occur during senescence (Borochov et al., 1982) and it has been theorized that leakage may occur due to these changes; perhaps at boundary layers between liquid and gel phases of the membrane (Ferguson, 1984). Another theory is that leakage may result from failure of certain membrane pumps that 
normally maintain a specific homeostasis (Palta et al., 1977). With changing membrane structure, the environment around the pumps changes and their activity may decrease. Evidence is increasing for this second explanation. For example, $\mathrm{H}^{+}$-ATPase pump activity has been shown to decrease as petals age (Torre et al., 1999). Channels exist in the plasma membrane that allow $\mathrm{K}^{+}$to move into or out of the cell to reach concentration and electrochemical equilibrium. In animal systems, these channels have been called $\mathrm{K}^{+}$ leak channels. If pumps in the membrane begin to fail, $\mathrm{K}^{+}$may not be pumped back into the cell at the same rate that it is leaking out. There is also a possibility that $\mathrm{K}^{+}$"leakage" is not a result of deteriorating membranes or membrane pumps, but part of a controlled process. We may theorize that $\mathrm{K}^{+}$is being released from the cell to maintain some cellular homeostasis or as part of a stress response. Studies of the timing of the events during senescence will be needed to clarify this issue. (For example, Huang et al. (1997) have studied senescing parsley leaves and have found that calcium pumps in the cell membranes decrease in their ability to expel $\mathrm{Ca}$ from the cells. But this decrease did not occur until two days after proteolysis began and signaled the last stages of senescence.)

In this study, $\mathrm{K}^{+}$leakage reflected total electrolyte leakage (Figures 6.1 and6.2.A.) and again, both cultivars followed the same pattern of increase over the vase life. The measure of $\mathrm{K}^{+}$from heat-killed tissue (Figure 6.2.B.) indicates that the total $\mathrm{K}$ in the tissue is increasing over the vase life. The concentration and pattern of increase is not statistically different for the two cultivars (on a dry weight basis).

The new $\mathrm{K}$ arriving at the petal tissue during the vase life could account for some part of the increase in $\mathrm{K}$ that was measured as leakage. In fact, this new $\mathrm{K}$ could account for all of the $\mathrm{K}$ measured as leakage. (By the same logic, the new $\mathrm{Ca}$ that arrives at the petals during the vase life could account for all of the increased Ca measured as leakage, too.)

The increase in apoplastic free calcium that occurs as roses senesce raises some questions. If cells lose the ability to maintain $\mathrm{Ca}$ homeostasis, they could not remain viable. And if indeed the membranes lost the ability to control Ca flux, it would seem likely that $\mathrm{Ca}$ would leak into the cells, not out of them. It is likely that this is not "leakage", but that the Ca is being freed from the cell wall. 
Evidence has been presented (Arora and Palta, 1988) that $\mathrm{K}^{+}$leaking out of the cells displaces $\mathrm{Ca}$ from sites on the membrane in onion scale cells subjected to freezethaw injury. It is possible that $\mathrm{K}^{+}$, as it leaks into the apoplast in senescing rose petals, is competing for exchange sites in the cell wall and displacing Ca. Cara Mia's longevity may be related to its higher amounts of free apoplastic Ca. The cell walls of Dakota petals may have more exchange sites that hold more calcium and allow less to be "free". This is supported by the fact that Dakota leaves contain more calcium than Cara Mia's when grown in exactly the same media, and therefore appear to require more calcium.

The modified leakage method used in this study made it possible to separate calcium into three fractions and to monitor the change in calcium in each fraction over the vase life. The first fraction, measured from the leakage solution, is free apoplastic calcium as described above.

The second fraction was measured in the heat-killed petal solution. This fraction represents the calcium that can be solublized by hot water. All of the remaining calcium was not in this fraction. Some remained bound in the petal residue and represents the calcium that was not solublized by the heat-kill treatment. The third fraction was this amount of calcium that remained bound in the residue after heat-killing. This fraction was not measured directly, but was calculated by subtracting the first two fractions from the total calcium as measured in the dry ashed petal tissue. Demarty et al. (1984) describe the cell wall as having two parts. The outer part includes the middle lamella. Calcium is involved in cross-linking the gel structure (mostly polygalacturonans) here. The calcium in this part can be extracted with hot water. The second part, the inner cell wall, is close to the plasma membrane and also contains pectic substances linked by calcium. The calcium in this inner part cannot be extracted by hot water.

Figure 6.6 shows all three of the calcium fractions from this study as they change during the vase life. Quantities are given as a percent of the total calcium. The "tightly held calcium" should only be considered as a general trend since these quantities were not directly measured. Free calcium in the apoplast makes up a very small part of the petal tissue calcium. Calcium released by heat-killing may represent calcium in the outer cell wall that is extractable by hot water. And the difference between calcium released by 
heat-killing and total calcium may represent calcium of the inner cell wall that is not extractable by hot water. This quantity is increasing over the vase life. The fraction that, according to Demarty's theory, represents Ca in the outer cell wall and middle lamella is decreasing over the vase life.

Differences in the cell walls may very well explain some of the genetic component to differences in postharvest performance in roses. A more detailed study of the cell wall and the allocation of calcium there is needed. 


\section{Summary and Conclusions}

From the research presented in this paper, it appears likely that a mixture of calcitic and dolomitic limes used in the media may improve postharvest performance of cut roses. Also, CBA as an amendment for peat-vermiculite media did not decrease rose yield. When media was made up of 50\% CBA, the roses produced had longer postharvest lives than the control roses (grown in $\mathrm{P}: \mathrm{V}$ with dolomitic lime) and were comparable to roses from P:V with a 1:1 mix of calcitic and dolomitic lime.

We propose that it is the calcium and/or the calcium/magnesium ratio in the media which improved vase life in this study. A relationship was shown between higher media calcium level, higher leaf calcium level (within cultivar) and longer vase life. This pattern was consistent for all four cultivars of roses tested, although each cultivar had its own characteristic leaf $\mathrm{Ca}$ level.

The calcium level in the rose petals themselves did not increase with higher media and leaf calcium. Petal calcium was very low; on the order of less than one tenth of that found in the leaf tissue. The level of petal calcium was not related to vase life. The beneficial effect of increased calcium is apparently exerted due to the increased calcium in the leaves and the benefits that the cut rose derives from this improved leaf calcium status.

A very interesting relationship was noted with respect to cultivar and calcium. Of the four cultivars used, two had long vase lives and two had short vase lives. The two long lived cultivars accumulated less calcium in their leaves and also in their petals than the two short lived cultivars. A possible explanation is that the accumulation of calcium is controlled by the exchange capacity of the plant cell walls. The two cultivars that accumulated less calcium may have a lower exchange capacity and therefore 'require' less calcium. The flower petals are low-transpiration organs and the calcium reaching them is limited. It may be an advantage (with respect to vase life) to require less calcium.

Calcium (and magnesium) levels in rose petals increased over the vase life. This occurred even though calcium is thought to be transported only through the xylem and the roses were held in distilled water during this time. It is possible that this additional 
calcium enters the xylem fluid by diffusion from the apoplastic spaces in the rest of the stem.

The cell walls make up approximately half of the petal dry weight. The amount of cell wall material appears to increase as Dakota flowers expand to full size, then to remain constant. In Cara Mia, there it was not a significant increase as expansion occurred, but there was a small measurable loss of cell wall material near the end of vase life. Virtually all of the measurable calcium was found in the cell wall fraction. Cytoplasmic calcium and calcium involved in signal transduction is a small enough quantity that it was not measurable by the methods used in this study. The calcium in the petal cell walls increased over the vase life (as does the total calcium) for both cultivars tested. Dakota (short vase life) had significantly more calcium per g of cell wall material than did Cara Mia. This is in keeping with our hypothesis that Dakota may have a greater exchange capacity in its cell walls.

Membrane leakage was measured as E.C. in the leachate from fresh petals. This parameter increased as vase life progressed, with the same timing for both cultivars. The increase in leakage should not necessarily be interpreted as a deterioration of the membrane or membrane pumps but perhaps as simply a measurement of changing apoplastic ion concentration. It is possible that the ion concentration in the apoplast is increasing as part of a controlled process; part of a stress response or homeostasis response. Also, our results show that more $\mathrm{K}, \mathrm{Ca}$, and $\mathrm{Mg}$ are arriving in the petals over the vase life and these quantities could account for the measured increases in leachate conductivity. Finding the actual source and possible function of the increasing ion concentration that is called 'leakage' will require more study.

In fractionating petal calcium into free calcium, hot water-extractable calcium, and tightly held calcium, we found that the free calcium was a very small fraction of the total, less than $8 \%$. The hot water-extractable calcium, which may represent calcium in the outer cell wall/pectin fraction, decreased as the vase life progresses. The tightly held calcium, which may represent calcium in the inner wall, increased. This indicates a movement of calcium in closer toward the cell membrane and a weakening of the middle lamella. It is possible that this is the chemical explanation of our very subjective 
observation that petals, as they senesce, change from having a 'crisp' feel to having an almost 'stretchy' feel.

The peak in ethylene production for Dakota (short vase life) occurred sooner that the peak in ethylene production for Cara Mia (long vase life) thereby indicating a possible relationship between ethylene production and senescence. Cara Mia, though, had a much higher ethylene production at its peak. Response to ethylene depends on ethylene sensitivity, which is, in part, determined by the kind and number of ethylene receptors made by the petals. Cara Mia may have a lower number of receptors, and therefore be less sensitive to ethylene than Dakota. A study of quantifying ethylene receptor production in petals of different cultivars could shed more light on this question. 


\section{Literature Cited}

Abeles, F.B., P.W. Morgan, and M.E. Saltveit. 1992. Measuring ethylene, p. 14-21. In: Ethylene in Plant Biology. 2nd ed. Academic Press, Inc. San Diego, CA.

Alonso, J., W. Canet, and T. Rodriguez. 1997. Thermal and calcium pretreatment affects texture, pectinesterase, and pectic substances from frozen sweet cherries. J. Food Sci. 62(3):511-515.

Altman, S.A. and T. Solomos. 1994. Inhibition of ethylene biosynthesis and action in cut carnation (Dianthus caryophyllus L.) by aminotriazole. J. Amer. Soc. Hort. Sci. 119(2):282-287.

Arora, R., M.E. Wisiniewski, and R. Scorza. 1992. Cold acclimation in genetically related (sibling) deciduous and evergreen peach (Prunus persica [L.]Batsch). Plant Physiol. 99:1562-1568.

Arora, R. 1990. Studies of membrane perturbations following a freeze-thaw cycle in herbaceous plant species. PhD Diss., Univ. of Wisconsin, Madison, WI.

Arora, R. and J.P. Palta. 1988. In vivo perturbation of membrane-associated calcium by freeze-thaw stress in onion bulb cells. Plant Physiol. 87:622-628.

Bascomb, C.L. 1964. Rapid method for the determination of cation-exchange capacity of calcareous and non-calcareous soils. J. Sci. Food Agric. 15:821-823.

Bearce, B.C., S. Meyers, M. Burch, B. Engstrom, and L. Smutna. 1997. Coal bottom ash as a growing media for poinsettia, Easter lily and peperomia. Pooc. 12th Intl. Symposium on Coal Combustion By-products (CCB) Management and Use. Vol. 1, 4-1 to 4-21. Bearce, B. C., D. L. Lentz, M. A. Woodard, and E. C. Townsend. 1993. Coal bottom ash as a root substrate for marigolds in a closed loop nutriculture system. Proceedings: 10th Intl. Ash Use Symposium, Vol. 1: High-Volume Uses/Concrete Application. EPR1 TR101774. American Coal Ash Assoc. Washington, D.C.

Bearce, B. C., and D. W. Leach. 1989. Coal ash and pine wood chips as a component of poinsettia root media. HortScience 24:222 (Abstr.)

Bieleski, R.L. 1995. Onset of phloem export from senescent petals of daylily. Plant Physiol. 109:557-565.

Boodley, J.W. 1969. Post harvest life, p. 144-149. In: J. W. Mastalerz and R. W. Langhans (eds.). Roses- A manual on the culture, management, diseases, insects, economics, and breeding of greenhouse roses. Pennsylvania Flower Growers, N.Y. State Flower Growers Assoc., Inc. 
Boodley, J.W. 1981. The Commercial Greenhouse Handbook. p. 481-495. Van Nostrand Reinhold Co. N. Y.

Borochov, A., A.H. Halevy, and M. Shinitzky. 1982. Senescence and fluidity of rose petal membranes. Plant Physiol. 69:296-299.

Borochov, A., and W.R. Woodson. 1989. Physiology and biochemistry of flower petal senescence. Hort. Rev. 11:15-43.

Broschat, T. K. 1995. Fertilization rate affects production and postharvest quality of Tapeinochilus ananassae flowers. HortScience 30:1013-1014.

Buchanan-Wollaston, V. 1997. The molecular biology of leaf senescence. J. Exp. Bot. 48:181-199.

Butler, S.H. and B.C. Bearce. 1995. Greenhouse rose production in media containing coal bottom ash. J. Environ. Hort. 13(4):160-164.

Carpita, N., M. McCann, and L.R. Griffing. 1996. The plant extracellular matrix: news from the cell's frontier. Plant Cell. 8:1451-1463.

Cornell Recommendations for Commercial Floriculture Crops. 1981. NY State College of Agriculture and Life Sciences at Cornell University, Ithaca, NY.

Cushman, L.C., H.B. Pemberton, and J.W. Kelly. 1994. Cultivar, flower stage, silver thiosulfate, and BA interactions affect performance of potted miniature roses. HortScience 29:805-808.

Dai, J. and R.E. Paull. 1995. Source-sink relationship and Protea postharvest leaf blackening. J. Amer. Soc. Hort. Sci. 120(3):475-480.

Demarty, M., C. Morvan, and M. Thellier. 1984. Calcium and the cell wall. Plant, Cell and Env. 7:441-448.

deVetten, N.C. and D.J. Huber. 1990. Cell wall changes during the expansion and senescence of carnation (Dianthus caryophyllus) petals. Physiol. Plant. 78:447-454.

D’Souza, M.C., S. Singha, and M. Ingle. 1992. Lycopene concentration of tomato fruit can be estimated from chromaticity values. HortScience. 27(5):465-466.

Embry, J. L., and E. A. Nothnagel. 1994. Leaf senescence of post-production poinsettias in low-light stress. J. Amer. Soc. Hort. Sci. 119:1006-1013.

Ferguson, I. B., C. B. Watkins, and J. E. Harman. 1983. Inhibition by calcium of senescence of detached cucumber cotyledons. Plant Physiol. 71:182-186. 
Ferguson, I.B. 1984. Calcium in plant senescence and fruit ripening. Plant, Cell and Env. 7:477-489.

Fry, S.C. 1989. Analysis of cross-links in the growing cell walls of higher plants. p. 1236. In: Modern Methods of Plant Analysis: NS. Vol 10. Springer-Verlag. Berlin. Heidelberg.

Gerasopoulos, D. and B. Chebli. 1999. Effects of pre- and postharvest calcium applications on the vase life of cut gerberas. J. Hort. Sci. and Biotech. 74(1):78-81.

Gonnet, J.F. 1995. A colorimetric look at the RHS chart - - perspectives for an instrumental determination of colour codes. J. Hort. Sci. 70:191-206.

Gutterson, N. 1995. Anthocyanin biosynthesis genes and their application to flower color modification through sense suppression. HortScience. 30(5):964-966.

Hadfield, K.A. and A.B. Bennett. 1998. Polygalacturonases: Many genes in search of a function. Plant Physiol. 117:337-343.

Halevy, A.H. and S. Mayak. 1979. Senescence and postharvest physiology of cut flowers, Part 1. Hort. Rev. 1:205-236.

Halevy, A.H. and S. Mayak. 1981. Senescence and postharvest physiology of cut flowers, Part 2. Hort. Rev. 3:59-143.

Hammer, P. E., and K.B. Evensen. 1996. Effects of the production environment on the susceptibility of rose flowers to postharvest infection by Botrytis cinerea. J. Amer. Soc. Hort. Sci. 121:314-320.

Han, S. S. 1995. Growth regulators delay foliar chlorosis of Easter Lily leaves. J. Amer. Soc. Hort. Sci. 120:254-258.

Harborne, J.B. 1988. Phenolic compounds, p. 37-99. In: Phytochemical Methods - a Guide to Modern Techniques of Plant Analysis. 2nd ed. Chapman and Hall, NY.

Hartley-Butler, S. 1993. Greenhouse rose production in media containing coal bottom ash. M.S. Thesis. West Virginia Univ., Morgantown, WV. 26506-6108.

Have, A. and E.J. Woltering. 1997. Ethylene biosynthesis genes are differentially expressed during carnation (Dianthus caryophyllus L.) flower senescence. Plant Mol. Bio. 34:89-97. 
Huang, F.Y., S.P. Hadas, S. Meir, D.A. Callaham, R. Sabato, A. Zelcer, and P.K. Hepler. 1997. Increase in cytosolic $\mathrm{Ca}^{+2}$ in parsley mesophyll cells correlate with leaf senescence. Plant Physiol. 115:51-60.

Itzhaki, H., S. Mayak, and A. Borochov. 1998. Phosphatidyl choline turnover during senescence of rose petals. Plant Physiol. Biochem. 36(6):457-462.

Jarvis, M.C. 1984. Structure and properties of pectic gels in plant cell walls. Plant Cell and Env. 7:153-164.

Jiménez, A., A. Heredia, R. Guillén, and J. Fernández-Bolaños. 1997. Correlation between soaking conditions, cation content of cell wall, and olive firmness during "Spanish green olive" processing. J. Agric. Food. Chem. 45:1653-1658.

Jones, R.B., M. Serek, C. Kuo, and M.S. Reid. 1994. The effect of protein synthesis inhibition on petal senescence in cut bulb flowers. J. Amer. Soc. Hort. Sci. 119(6):12431247.

Kanabo, I.A.K. and R.J. Gilkes. 1987. A comparison between plant response and chemical measurements of the dissolution of reactive phosphate rock in soils of different $\mathrm{pH}$ and phosphorous retention. Aust. J. Soil Res. 25:451-460.

Karle, R. and T.H. Boyle. 1999. Relationship between floral morphology, breeding behavior, and flower longevity in Easter Cactus. J. Am. Soc. Hort. Sci. 124(3):296-300.

Ketsa, S. and A. Rugkong. 1999. Senescence of Dendrobium 'Pompador' flowers following pollination. J. Hort. Sci. and Biotech. 74(5):608-613.

Kobayashi, M., H. Nakagawa, T. Asaka, and T. Matoh. 1999. Boraterhamnogalacturonan II bonding reinforced by $\mathrm{Ca}^{2+}$ retains pectic polysaccharides in higher plant cell walls. Plant Physiol. 119(1):199-203.

Lancaster, J.E., J.E. Grant, C.E. Lister, and M.C. Taylor. 1994. Skin color in apples influence of copigmentation and plastid pigments on shade and darkness of red color in five genotypes. J. Amer. Soc. Hort. Sci. 119:63-69.

Lim, C.C., R. Arora, and E.C. Townsend. 1998. Comparing Gompertz and Richards functions to estimate freezing injury in Rhododendron using electrolyte leakage. J. Amer. Soc. Hort. Sci. 123(2):863-868.

Marschner, H. 1995. Mineral nutrition of higher plants. 2nd ed. Academic Press, Harcourt Brace, London. 297-298.

Matile, P.S. Hörtensteiner, H. Thomas, and B. Kräutler. 1996. Chlorophyll breakdown in senescent leaves. Plant Physiol. 112:1403-1409. 
Mattoo, A.K. and N. Aharoni. 1988. Ethylene and plant senescence, p. 241-280. In: L.D. Noodén and A.C. Leopold (eds.). Senescence and Aging in Plants. Academic Press, Harcourt Brace, San Diego, CA.

Mayak, S. and A.H. Halevy. 1972. Interrelationships of ethylene and abscisic acid in the control of rose petal senescence. Plant Physiol. 50:341-346.

Mayak, S., A. H. Halevy, S. Sagie, A. Bar-Yoseph, and B. Bravdo. 1974. The water balance of cut rose flowers. Physiol. Plant. 31:15-22.

Mazza, G. and R. Brouillard. 1990. The mechanism of copigmentation of anthocyanins in aqueous solutions. Phytochemistry. 29(4):1097-1102.

Mitchell, K.A., K.R. Markham, and M.R. Boase. 1998. Pigment chemistry and colour of Pelargonium flowers. Phytochem. 47(3):355-361.

Mor, Y. and N. Zieslin. 1987. Plant growth regulators in rose plants. Hort. Rev. 9:5373.

Müller, R., S. Lind-Iversen, B.M. Stummann, and M. Serek. 2000. Expression of genes for ethylene biosynthetic enzymes and an ethylene receptor in senescing flowers of miniature potted roses. J. Hort. Sci. and Biotech. 75(1):12-18.

Nelson, P.V. 1998. Fertilization, p. 285-353. In: Greenhouse Operation and Management, 5th ed. Prentice Hall, Upper Saddle River, N.J.

Nichols, L. P., and P. V. Nelson. 1969. Foliage diseases. p. 185-195. In: J. W. Mastalerz and R.W. Langhans (eds.), Roses - A manual on the culture, management, diseases, insects, economics, and breeding of greenhouse roses. Pennsylvania Flower Growers, N.Y. State Flower Growers Assoc., Inc.

Oeller, P.W., L. Min-Wong, L.P. Taylor, D.A. Pike, and A. Theologis. 1991. Reversible inhibition of tomato fruit senescence by antisense RNA. Science. 254:437-439.

Ohkawa, K., Y. Kasahara, and J. Suh. 1999. Mobility and effect on vase life of silvercontaining compounds in cut rose flowers. HortScience. 34(1):112-113.

O'Neill, S.D., and J.A. Nadeau. 1997. Postpollination flower development. Hort. Rev. 19:1-58.

Onofrey, D. 1997. Top 100 growers - State of the industry. Greenhouse Grower 15:1528. 
Palta, J.P., J. Levitt, and E.J. Stadelmann. 1977. Freezing injury in onion bulb cells. Plant Physiol. 60:393-397.

Pertwee, J. 1995. The Production and Marketing of Roses. 2nd ed. Pathfast Pub. Essex, England.

Pi Alpha Xi Judging Standards Committee. 1983. A Manual for Flower Judging. 6th ed. Pi Alpha Xi, Pullman, WA.

Pitchay, D.S. 1996. Performance of impatiens, ivy and zonal geraniums, petunias and poinsettias in coal bottom ash substrates. M.S. Thesis. West Virginia University, Morgantown, WV. 26506-6108.

Poovaiah, B. W. 1988. Calcium and senescence, p. 369-389. In: L. D. Noodén and A. C. Leopold (eds.). Senescence and aging in plants. Academic Press. San Diego, CA.

Poovaiah, B.W., G.M. Glenn, and A.S.N. Reddy. 1988. Calcium and fruit softening: physiology and biochemistry. Hort. Rev. 10:107-152.

Quintana, J.M., H.C. Harrison, J.P. Palta, J. Nienhuis, and K. Kmiecik. 1999. Calcium fertilizers fail to affect pod calcium concentration and yield of four snap bean cultivars. HortScience. 34(4):646-647.

Reid, M.S., R.Y. Evans, and L.L. Dodge. 1989. Ethylene and silver thiosulfate influence opening of cut rose flowers. J. Amer. Soc. Hort. Sci. 114:436-440.

Roberts, G.L., M.J. Tsujita, and B. Dansereau. 1993. Supplemental light quality affects bud break, yield, and vase life of cut roses. HortScience 28:621-622.

Saltveit, M.E. 1982. Procedures for extracting and analyzing internal gas samples from plant tissues by gas chromatography. HortScience 17(6):878-881.

Saltviet, M.E. 1984. Variations among gas chromatographic measurements of ethylene standards. HortScience. 19(4):488-490.

Savin, K.W., S.C. Baudinette, M.W. Graham, M.Z. Michael, G.D. Nuget, C. Lu, S.F. Chandler, and E.C. Cornish. 1995. Antisense ACC oxidase RNA delays carnation petal senescence. HortScience 30(5):970-972.

Scott, D., T.H. Boyle, and S.S. Han. 1994. Floral development and flower longevity in Rhipsalidopsis and Schlumbergera (Cactaceae). HortScience 29:898-900

Serek, M., M.S. Reid, and E.C. Sisler. 1994.a. A volatile ethylene inhibitor improves the postharvest life of potted roses. J. Amer. Soc. Hort. Sci. 119(3):572-577. 
Serek, M., R.B. Jones, and M.S. Reid. 1994.b. Role of ethylene in opening and senescence of Gladiolus sp. flowers. J. Amer. Soc. Hort. Sci. 119:1014-1019.

Serek, M., E.C. Sisler, and M.S. Reid. 1994.c. Novel gaseous ethylene binding inhibitor effects in potted flowering plants. J. Amer. Soc. Hort. Sci. 119:1230-1233.

Siddiqui, S. and F. Bangerth. 1995. Differential effect of calcium and strontium on flesh firmness and properties of cell walls in apples. J. Hort. Sci. 70(6):949-953.

Singha, S., T.A. Baugher, E.C. Townsend, and M.C. D’Souza. 1991. Anthocyanin distribution in 'Delicious' apples and the relationship between anthocyanin concentration and chromaticity. J. Amer. Soc. Hort. Sci. 116(3):497-499.

Singha, S. and E.C. Townsend. 1989. Relationship between chromaticity values and chlorophyll concentration in apple, grape, and peach leaves. HortScience. 24(6):1034.

Smigocki, A.C. 1995. Phenotype modification and enhanced tolerance to insect pests by regulated expression of a cytokinin biosynthesis gene. HortScience 30:967-969.

Staby, G. 1994. Flower and plant care manual - a contemporary approach. The Society of American Florists, publishers.

Starkey, K.R. and A.R. Pedersen. 1997. Increased levels of calcium in the nutrient solution improves the postharvest life of potted roses. J. Amer. Soc. Hort. Sci. 122(6):863-868.

Steet, J.A. and C.H. Tong. 1996. Degradation kinetics of green color and chlorophylls in peas by colorimetry and HPLC. J. Food Sci. 61:924-927.

Thompson, J.E. 1988. The molecular basis for membrane deterioration during senescence, p. 51-83. In: L.D. Noodén and A.C. Leopold (eds.). Senescence and aging in plants. Academic Press. San Diego, CA.

Tjosvold, S.A., M. Wu, and M.S. Reid. 1994. Reduction of postproduction quality loss in potted miniature roses. HortScience 29:293-294.

Torre, S., A. Borochov, and A.H. Halevy. 1999. Calcium regulation of senescence in rose petals. Physiol. Plant. 107:214-219.

van Doorn, W.G. 1998. Effects of daffodil flowers on the water relations and vase life of roses and tulips. J. Amer. Soc. Hort. Sci. 123(1):146-149.

van Doorn, W.G., and Y. de Witte. 1997. Sources of the bacteria involved in vascular occlusion of cut rose flowers. J. Amer. Soc. Hort. Sci. 122:263-266. 
van Doorn, W.G., and Y. de Witte. 1994. Effect of bacteria on scape bending in cut Gerbera jamesonii flowers. J. Amer. Soc. Hort. Sci. 119:568-571.

Van Eijk, J.P., and W.E. Boom. 1976. Possibilities of selection for keeping quality in tulip breeding. Euphytica 25:353-359.

Voigt, A. O. 1997. Focus on domestic cut flowers/greens, 1990-1995. Flower Marketing Information. April. State College. PA.

Wagner, D.F., and J.C. Neal. 1984. Coal cinders with pine bark as azalea growing media. J. Amer. Soc. Hort. Sci. 109:822-826.

Warncke, D. 1991. Recommended test procedures for greenhouse growth media, p. 5764. In: Recommended Soil Testing Procedures for the Northeastern United States. NE Regional Publication No. 493.

Wernett, H.C., T.J. Sheehan, G.J. Wilfret, F.J. Marousky, P.M. Lyrene, and D.A. Knauft. 1996. Postharvest longevity of cut flower Gerbera. I. Response to selection for vase life components. J. Amer. Soc. Hort. Sci. 121:216-221.

Woodard, M.A. 1992. Influence of coal bottom ash and pinewood peelings on plants grown with a recirculated nutrient solution. M. S. Thesis. West Virginia Univ., Morgantown, WV. 26506-6108.

Woodson, W.R. and K.A. Lawton. 1988. Ethylene-induced gene expression in carnation petals. Plant Physiol. 87:498-503.

Wright, R.D. 1986. The pour-through nutrient extract procedure. HortSci. 21(2):227229.

Yip, W.K. and S.F. Yang. 1993. Ethylene metabolism, p. 432-433. In: P.J. Lea. (ed.). Methods in plant biochemistry, Vol. 9, Enzymes in secondary metabolism. Academic Press, London. 


\section{Appendix}

Tables and figures in the Appendix are labeled with A (for "appendix"). The number immediately following the $\mathrm{A}$ indicates the text chapter to which that table or figure relates. 


\begin{tabular}{|l|c|c|}
\multicolumn{1}{c|}{} & Calcitic Lime & Dolomitic Lime \\
\hline Elemental calcium & $35 \%$ & $21 \%$ \\
\cline { 1 - 1 } Calcium oxide & $49 \%$ & $29 \%$ \\
\cline { 1 - 1 } Calcium carbonate & $88 \%$ & $52 \%$ \\
\cline { 1 - 1 } Elemental Mg & $1.0 \%$ & $12 \%$ \\
\cline { 1 - 1 } Magnesium oxide & $1.7 \%$ & $19 \%$ \\
\cline { 1 - 1 } Mg carbonate & $3.5 \%$ & $40 \%$ \\
\cline { 1 - 1 } Ca carb. Eqiuvalent & $93 \%$ & $100 \%$ \\
\cline { 1 - 1 } at 10 mesh & $100 \%$ passes & $100 \%$ passes \\
\cline { 1 - 1 } at 20 mesh & $98 \%$ passes & $50 \%$ passes \\
\cline { 1 - 1 } at 60 mesh & $90 \%$ passes & $35 \%$ passes \\
\cline { 1 - 1 } at 100 mesh & $90 \%$ passes \\
\hline
\end{tabular}

Table A-2.1. Listing of the components of calcitic and dolomitic lime as listed on the producer's bag.

\begin{tabular}{|c|c|}
\hline Cultivar & Mean vase life (days) \\
\hline Cara Mia & 14.1 \\
\hline Dakota & 8.5 \\
\hline Pink Osiana & 16.5 \\
\hline Santa Fe & 9.4 \\
\hline
\end{tabular}

Table A.2.2. Mean vase life for each of the four rose cultivars used in this study. Means were calculated over all media. 
Please rate each set of 4 roses for each of the qualities listed. Rate each on a scale of 1 - 10, with 10 being perfect.

ROSE: A B C D

1. The stem below the flower is not bent or weak

2. Flower shape is normal - no bullheads

3. The color is fresh, intense and clear*

4. Flowers are normal sized, not "peanut".

5. The stem is stiff and strong.

6. The stem is straight** without side buds or shoots.....

7. Inner petals are healthy, turgid and undamaged...........

8. Outer petals are healthy, turgid and unblemished

9. The foliage is green (not chlorotic) and typical size

Please rate the quality of the scent (scale of $1-10$ with 10 being the nicest) and the strength of the scent (also scale of 1 - 10 - but you may choose a number higher than 10 if you think that the scent is too strong)

ROSE: A B C D

1. Quality of the scent

2. Strength of the scent

*=no bluing or purpling of red and pink cultivars, no greening of yellows, no dirty or soiled look in white or light cultivars.

$* *=$ the longitudinal axis of the flower coincides with the vertical axis of the stem.

Figure A.3.1. The above is a sample of the questionnaire used by the judges to evaluate the quality of Dakota and Cara Mia roses. 


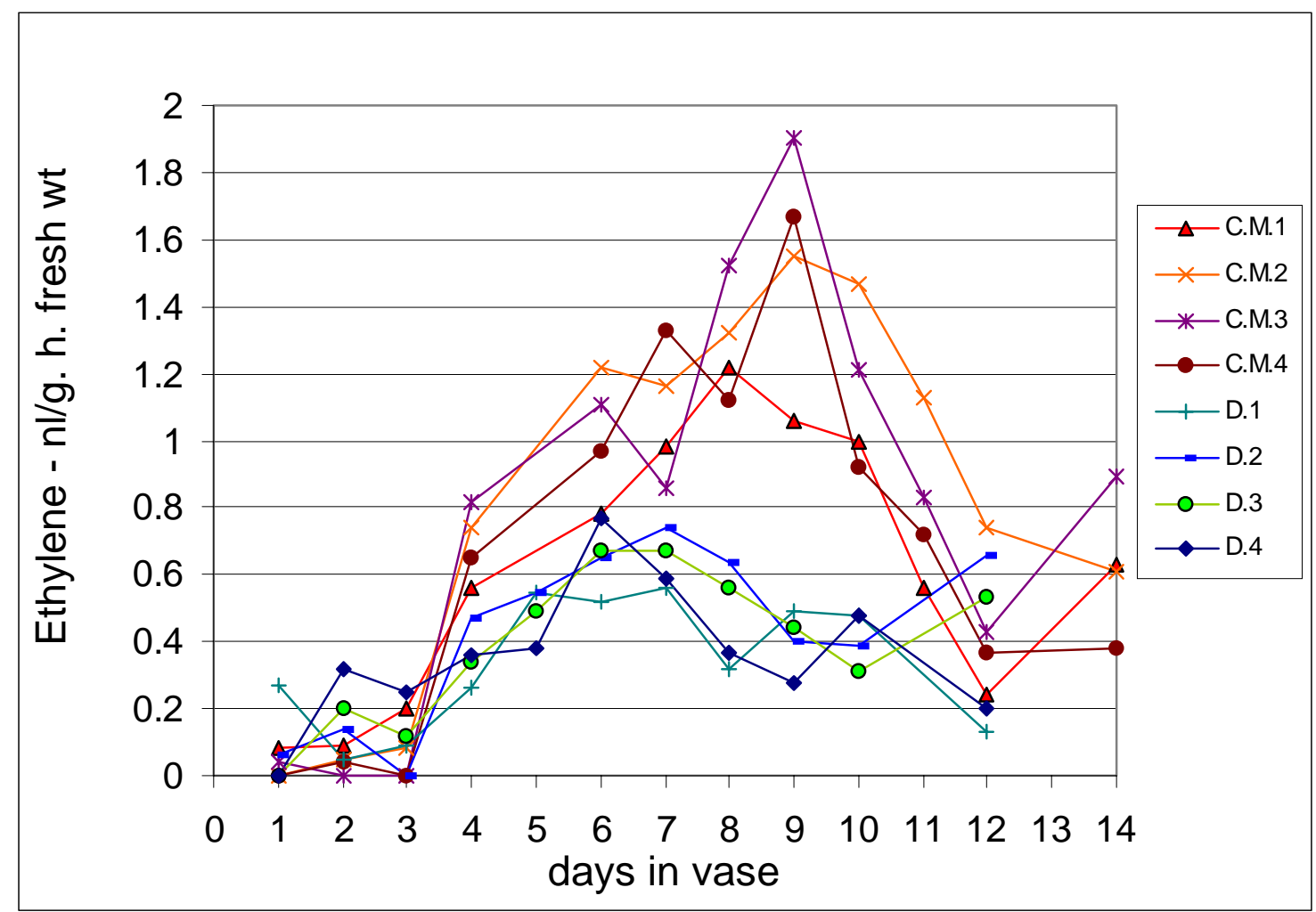

Figure A.4.1. Ethylene production by fresh rose petals over the vase life. Curves are shown for each media/cultivar combination. Note: while the two cultivars were significantly different, no evidence of a difference due to media was found. 


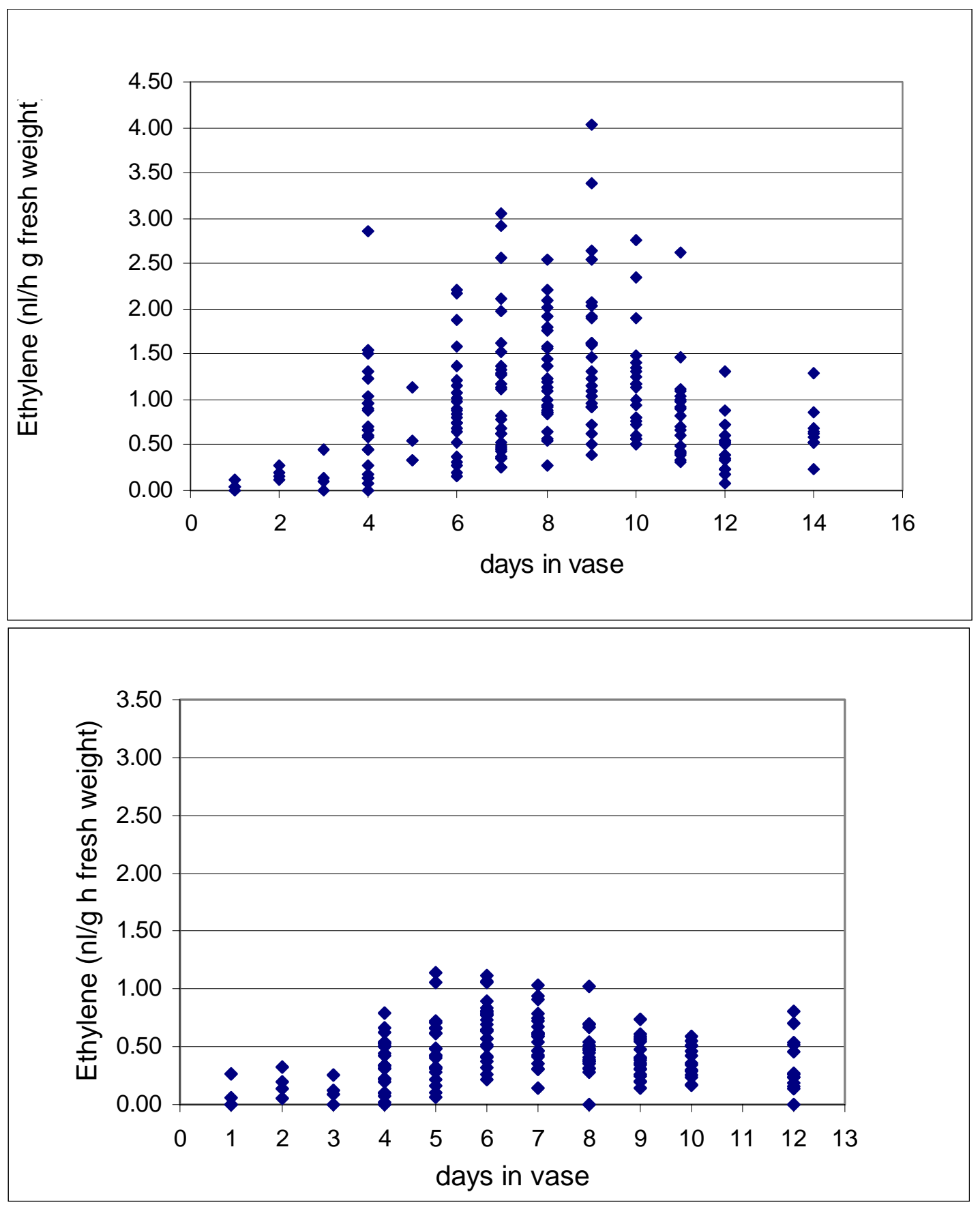

Figure A.4.2. Scatter plot of rose ethylene production by fresh petals over the vase life. Top=Cara Mia; Bottom=Dakota. 
SOURCE

VAR

BLK(VAR)

TR

$\mathrm{VAR} * \mathrm{TR}$

COL(BLK)

ROW(BLK)

VAR $*$ TR $*$ COL $*$ ROW $(B L K)$

DAY

VAR*DAY

TR*DAY

VAR*TR*DAY

ERROR
DF

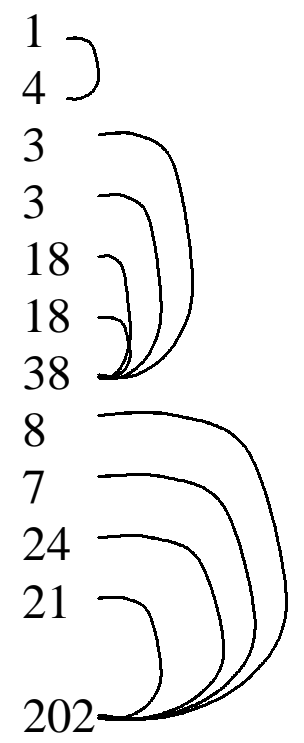

Figure A.4.3. Statistical model used to analyze ethylene data. 


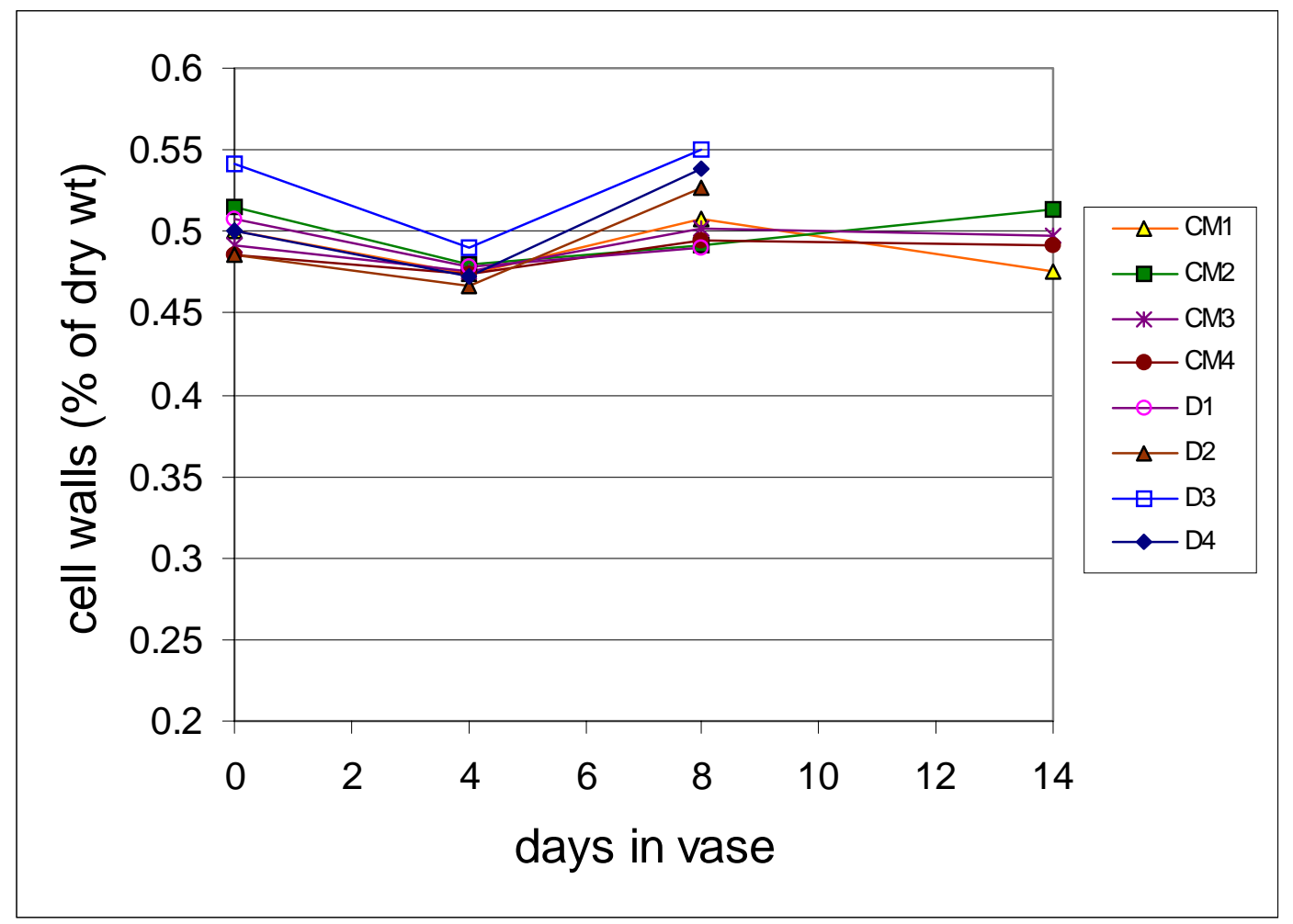

Figure A.5.1. The amount of cell wall material as a $\%$ of dry weight. Both cultivars are shown. To see the two cultivars seperately, see Figure A.5.5.b. and A.5.5.c. D=Dakota; $\mathrm{CM}=$ Cara Mia; $1=50 \% \mathrm{CBA} ; 2=25 \% \mathrm{CBA} ; 3=\mathrm{P}: \mathrm{V} / \mathrm{dol}$; and 4=P:V/dolcal. 

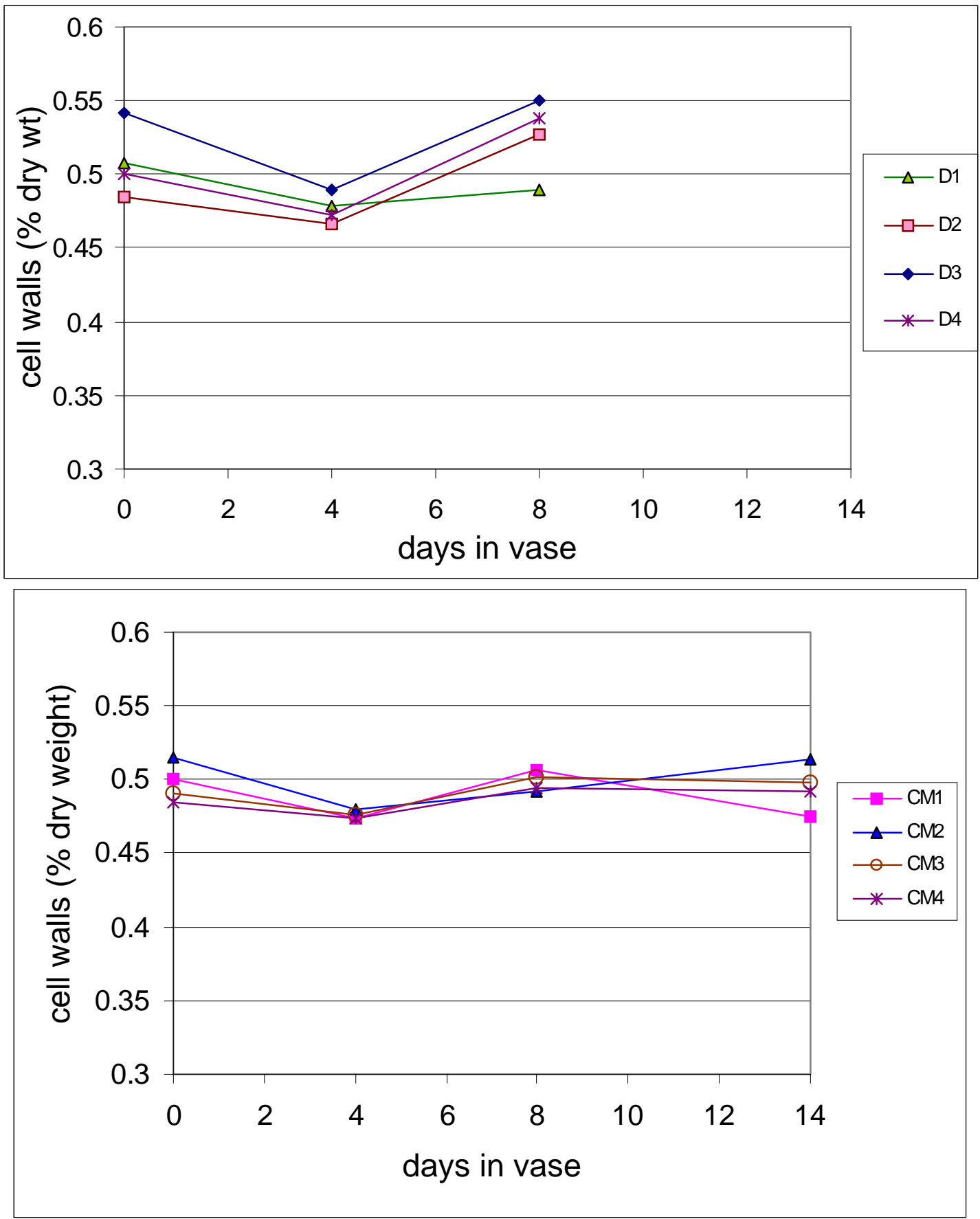

Figure A.5.2 Cell walls from the petals of two rose cultivars, as a \% of dry petal weight. Dakota (top graph) and Cara Mia (bottom graph) flowers grown in all four media are shown. 


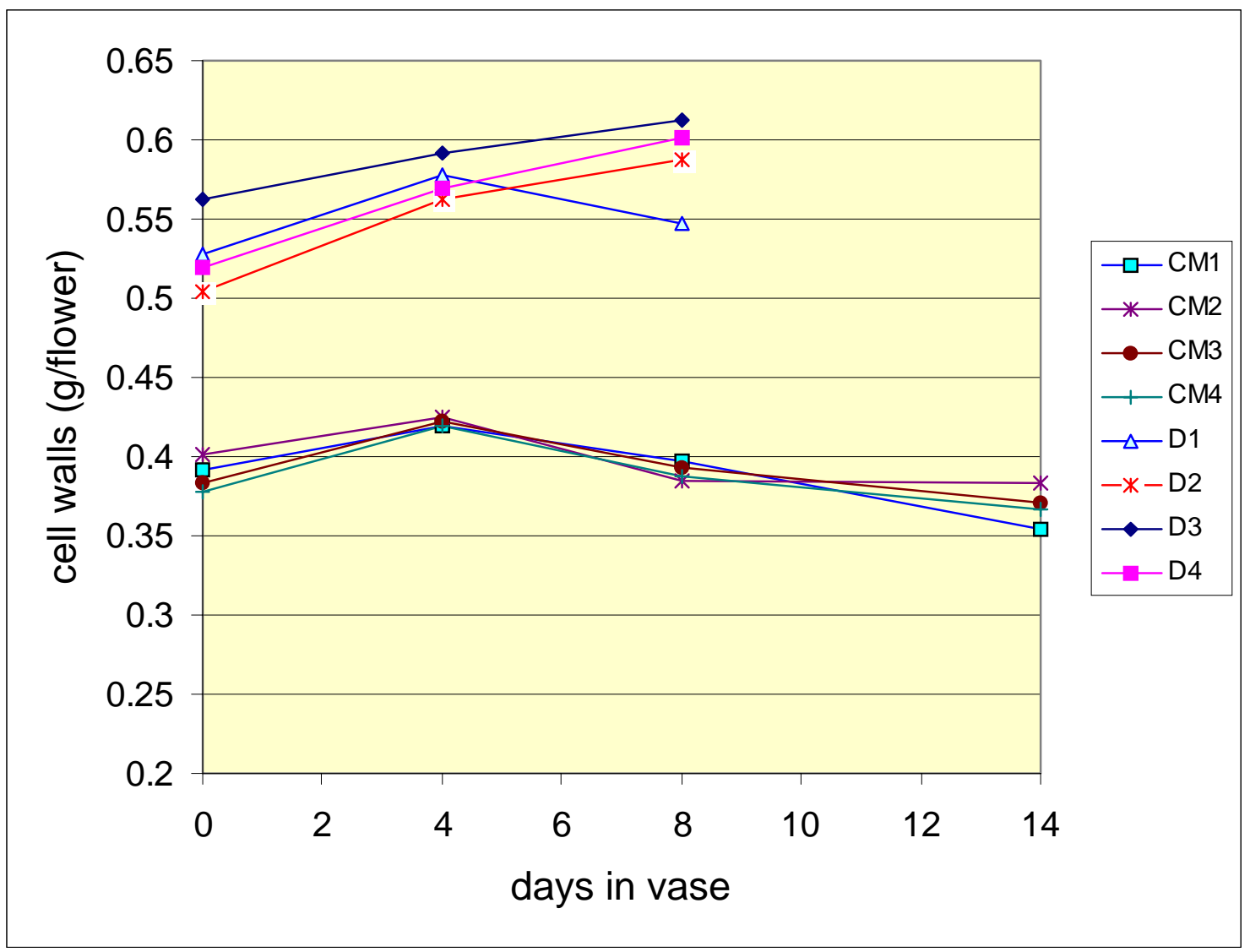

Figure A.5.3. The amount of cell wall material in $\mathrm{g}$ per one flower's petals. No difference was found due to media, but media values are graphed separately to show variation. $\mathrm{D}=$ Dakota; $\mathrm{CM}=$ Cara Mia; $1=50 \%$ CBA; $2=25 \%$ CBA; 3=P:V/dol; and 4=P:V/dolcal. 
VAR

BLK(VAR)

17

TR

VAR $*$ TR

COL(BLK)

ROW(BLK)

VAR $*$ TR $*$ COL $*$ ROW(BLK)

DAY

DAY*DAY

DAY*DAY*DAY

DAY*VAR

DAY*DAY*VAR

DAY*DAY*DAY*VAR

DAY*TR

DAY*DAY*TR

DAY*DAY*DAY*TR

DAY*VAR*TR

DAY*DAY*VAR*TR

DAY*DAY*DAY*VAR*TR

ERROR

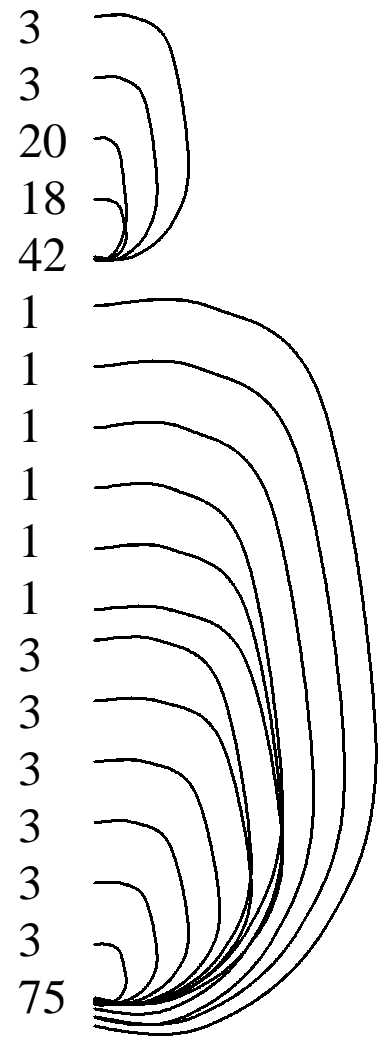

Figure A.6.1. Statistical model used to analyze leakage data. 


\section{Curriculum Vitae \\ Marlene Cross \\ 739 Wells St \\ Morgantown, WV 26505}

(304) 284-8245

mcross2@wvu.edu

\section{Education}

Doctor of Philosophy, Plant Science, graduation - May,2000.

West Virginia University, Morgantown, WV.

Advisor: Dr. Bradford Bearce.

Dissertation: Quality and postharvest performance of cut roses grown in media containing coal bottom ash.

Master of Science, Genetics and Developmental Biology, 1987.

West Virginia University, Morgantown, WV.

Advisor: Dr. Valentine Ulrich

Thesis: The effect of heterosis and gibberellic acid on RNA synthesis in protoplasts of the Kennebec potato and its related dihaploid.

Bachelor of Science, Biology, minor in Chemistry, 1975. Indiana University of Pennsylvania, Indiana, PA.

\section{Teaching Experience}

Plant Science Teaching Assistant, West Virginia University, August 1996 to May 1998.

Set up and assisted in teaching Plant Science Labs each semester to 2 - 3 sections of undergraduate students.

Biology Instructor - Adjunct, Fairmont State College, WV. Fall semester, 1996.

Planned and taught lectures and weekly labs of undergraduate general biology.

Horticultural Assistant, Lord Fairfax Community College, VA. May 1989 to August 1993.

Managed two teaching greenhouses, set up and helped teach labs to horticulture and natural resource students, supervised work-study students. 
Botany Instructor - Adjunct, Lord Fairfax Community College, Fall, 1988. Planned and taught lectures, weekly labs, and field trips to horticulture and natural resource majors.

Genetics Teaching Assistant, West Virginia University, August. 1976 to May, 1978.

Planned, set up and taught three sections of undergraduate genetics labs for four semesters.

\section{Research Experience}

Graduate Research Assistant, West Virginia University, May 1998 to present. Planned and conducted research for the horticulture department dealing with coal bottom ash as a component of the growing media, and the allocation of calcium as it relates to senescence.

Atomic absorption spectrophotometry.

Gas chromatography.

Production and maintenance of cut rose crop.

Agricultural Technician, Virginia Tech Fruit Research Lab, Winchester, VA, March, 1995 to August, 1995.

Assisted with research on apple and peach production including following a schedule of experimental spraying and data collection.

Monitored orchard plots, both research and private, for insect pest management program. Reported progress at grower's meetings.

Graduate Research Assistant, West Virginia University, 1984 to1987.

Planned and conducted research for the genetics department using tissue culture and RNA-isolation techniques in the study of hybrid vigor.

\section{Publications}

Postharvest performance of cut roses grown in root media containing coal bottom ash. M. Cross, B. Bearce, R. Arora, C.C. Lim, and E. Townsend. Poster presentation at the North East Regional Meeting of the ASHS, January, 1999.

Abstract: HortScience, 34(2)208. 1999. 
Vase life of cut roses grown in coal bottom ash-amended media: a correlation with tissue calcium. M. Cross, B Bearce, and R. Arora. Paper in preparation.

This work will also be presented as a poster at the ASHS conference, July, 2000 .

Differences in the synthesis of total and poly(A)+RNA in the Kennebec potato and its dihaploid. M.K. Cross, W.J. Kaczmarczyk, R.J. Young, V. Ulrich. Biologia Plantarum Prague. 1993. 35(3)349-354. 